\title{
Competition, Small Business Financing, and Discrimination: Evidence From a New Survey
}

\author{
Ken Cavalluzzo \\ McDonough School of Business \\ Georgetown University \\ Washington, DC 20057 \\ cavalluk@gunet.georgetown.edu \\ 202-687-8401 \\ Linda Cavalluzzo \\ Center for Naval Analyses \\ 4401 Ford Avenue \\ Alexandria, VA 22302 \\ cavallul@cna.org \\ 703-824-2197 \\ John Wolken \\ Board of Governors \\ Federal Reserve System \\ Washington, DC 20551 \\ jwolken@frb.gov \\ 202-452-2503
}

February, 1999

We thank Nicole Meleney for excellent research assistance. We appreciate the comments of Bob Avery, Glenn Canner, and seminar participants at the McDonough School of Business, Georgetown University. The authors are grateful to the Federal Reserve for the use of the data. The views expressed herein are those of the authors. They do not reflect the opinion of the Federal Reserve, The Board of Governors, or its staff. 


\begin{abstract}
Using data from the 1993 National Survey of Small Business Finances, we examine some of the factors influencing differences in small business credit market experiences across demographic groups. We analyze credit applications, loan denials, and interest rates paid across gender, race and ethnicity of small business owners. In addition, we analyze data gathered from small business owners who said they did not apply for credit because they believed that their application would have been turned down. This set of analyses, in combination with important new information on the personal credit history of the principal owner, the business credit history of the firm, a rich set of additional explanatory variables, and information on local bank market structure, helps us to understand better the sources of observed differentials in the credit market experiences of small business operators across demographic groups.

Credit market experiences often differ markedly among demographic groups. However, so do the characteristics of firms and owners. Results of our multivariate analyses show that many of the factors we consider help to explain the observed differences in credit market experiences. However, even after controlling for a large number of firm and owner characteristics, substantial differences often remained. There was also evidence that some of the differentials were associated with the degree of lender market concentration in the firm's local area.
\end{abstract}

$J E L(J 71, D 40)$ 


\section{Table of Contents}

I. Introduction $\quad 4$

Overview of Results $\quad 5$

II. Theory and Background $\quad 8$

III. Data and Descriptive Statistics $\quad 11$

Data 11

Descriptive Statistics $\quad 12$

IV. Empirical Approach 15

Analyses and Dependent Variables $\quad 15$

$\begin{array}{ll}\text { Model Specifications } & 17\end{array}$

Statistical Controls $\quad 18$

V. Results 19

Apply Analysis (Apply) 19

Credit Needs and Application Avoidance (FearDen) 20

Denied Analysis $\quad 21$

$\begin{array}{ll}\text { Ever Denied (EverDen) } & 21\end{array}$

Influence of Selection Bias on Estimated Effects (EverDen2) 23

Denied Most Recent Loan (DenMRL) 25

Interest Rate Analysis (IntRate) 26

VI. Analysis of Lines of Credit $\quad 28$

Results $\quad 29$

VII. Conclusions $\quad 30$

VIII. References

IX. Tables $1-10 \quad 39$

$\begin{array}{ll}X \text {. Appendices } & 55\end{array}$

Appendix A: Loan Analysis $\quad 56$

Appendix B: Sensitivity Tests $\quad 59$

Appendix C: Statistical Controls $\quad 70$

Appendix D: Joint Tests of Significance for Demographic, HHI, and Demographic Interaction Variables 75

Appendix E: Estimated Coefficients for Model 4 of Main Models,
Lines of Credit, and Loan Analysis 


\section{Introduction}

Despite a recent survey (Selz, 1996) that documented dramatic race-based differences in the credit market experiences of small business owners, very little is known about the sources of these differentials. The purpose of this paper is to shed light on some of the potential factors that influence observed differences in the credit market experiences of small businesses across demographic groups. We analyze credit applications, loan denials, and interest rates paid. In addition, we examine data gathered from small business owners who said they did not apply for credit because they believed that their application would have been turned down. Where possible, for each of our analyses, we also examine a single loan type, lines of credit. ${ }^{1}$ Doing so allows us to assess the extent to which our results are influenced by the heterogeneity of loan types. In each analysis, we take advantage of newly available cross-sectional data on small businesses and information on the extent of competition in small business credit markets to gain a better understanding of the sources behind the differences in credit market experiences across demographic groups.

It is well known that demographic differentials in credit market experiences may arise for a variety of reasons. Financial characteristics of the firm, the credit history of the firm and its owner, the age, experience, and education of the principal owner, a firm's credit (risk) score, firm relationships with financial institutions and suppliers, as well as other firm and owner characteristics all may influence the credit market experiences of small business operators. However, even after controlling for these factors, differentials across demographic groups may remain. If economically important factors that are used by lenders in the loan granting or rate setting process are correlated with demographic group, but are left uncontrolled by the researcher, then the estimated demographic coefficients will be biased by these omitted variables. Alternatively, lenders may be unable to observe, or it may be costly to collect, economically relevant information that is correlated with demographic group. If these lenders use demographic attributes as a proxy for missing information, then the resulting disparate treatment has an economic basis. This form of disparate treatment is called statistical discrimination (Phelps, 1972). Differentials may also arise because of the preferences of the lender - commonly

\footnotetext{
${ }^{1}$ The 1993 NSSBF collected data on six loan types: lines of credit, capital leases, business mortgages, equipment loans, vehicle loans, and "other" loans. Lines of credit were the most widely held loan type. About 60 percent of small businesses reported one or more loans. Approximately 25 percent of small businesses reported one or more outstanding lines of credit in 1993. And 52 percent of the most recent loans were lines of credit.
} 
referred to as non-economic or "prejudicial" discrimination. Finally, differentials may arise from differences in preferences for credit use on the part of the borrower.

We use data from the 1993 National Survey of Small Business Finances (NSSBF) to examine the degree to which information on firm and owner characteristics explains the observed univariate differences in credit market experiences of small businesses. The NSSBF data set is the most extensive public data set available on small businesses. We supplement these data with information furnished by the Board of Governors of the Federal Reserve on local bank market structure and Dun and Bradstreet credit scores for the firm. An important feature of the NSSBF data set is that it includes firms that do not use credit markets. These data allow us to test for possible selection biases (Heckman 1979), and to investigate the extent to which feedback effects were present (Arrow, 1973). In the present setting, feedback effects would arise if discriminatory practices limited access to credit, and as a result of this limited access, firms from the affected group subsequently did not apply for a loan.

Specifically, we examine whether minority or female small business operators were: (1) less likely to apply for loans or lines of credit, (2) more likely to report that they did not apply for a loan because they thought they would be turned down, (3) more likely to be denied credit on any loan applied for in the last three years, (4) less likely to have their credit needs met, (5) more likely to be denied credit on their most recent application and, (6) more likely to face higher interest rates than small businesses owned by white-males. In each analysis, we investigate the importance of the financial characteristics of the firm, the characteristics of the principal owner (e.g. owner education, age, and years of work experience), information on self-reported firm and owner credit history, a credit score constructed by Dun and Bradstreet, and information regarding a firm's relationships with financial institutions and suppliers. We also interact demographic indicators with a proxy characterizing the extent of competition in the firm's local geographic area. To the extent that lenders have more liberty to exercise their tastes in less competitive markets, differentials associated with lender market concentration are consistent with Becker's (1971) early theories of discrimination.

\section{Overview of Results}

Our first analysis examines the propensity to apply for a loan. With the exception of Asian owners, all else equal, our analysis reveals no differences in the propensity of small business owners to have applied for credit across demographic groups. This result holds for all 
loans and for lines of credit separately. Important factors in the decision to apply for credit include a firm's use of credit from suppliers, the education of the owner, the number of firm financial relationships and various measures of firm size, including a firm's asset base and number of employees. Firm profitability appeared to play no role in the decision to apply for credit. Similarly, firm self-reported indicators of credit history played a surprisingly limited role in the decision to apply for credit. Finally, there was no evidence that remaining differentials varied with lender market concentration.

Our second analysis explores firms' self-reported credit needs and application avoidance (not applying because the firm believed it would be turned down). Self-reported credit needs on the part of African Americans and Hispanics exceeded those of white-owned businesses by between 25 and 77 percent. In combination with our analysis of application rates above, this finding suggests that feedback effects may be present. Factors influencing application avoidance were whether the firm had ever been denied trade credit, and a firm's assets and sales-to-assets ratio. There was also evidence of an important role for firm and owner self-reported credit history, as well as the independently tabulated Dun and Bradstreet firm credit score. However, even after including a broad set of controls, our analysis of application avoidance reveals that African American- and Hispanic-, but not Asian-owned firms, were more likely to have avoided applying for credit than firms owned by white males. These differences were not statistically related to lender market structure. There was some evidence though that female-owned firms were more likely to have avoided applying for credit as lender market concentration increased.

Our next set of analyses focused on denial rates across demographic group. We considered three aspects of the denial decision: (1) Has the firm been denied a loan anytime within the last three years? (2) Has the firm been denied credit, or were there times when the firm needed credit over the last three years but did not apply for fear of being turned down? (i.e., Have the firm's credit needs within the past three years been met?) and (3) Was the firm denied credit on its most recent loan? Firm assets, the Dun and Bradstreet credit score, many of the firm's self-reported credit history variables, in addition to whether the firm has ever been denied credit by suppliers played important roles in explaining differentials across demographic groups. Nonetheless, even after including these factors, substantial differences across some demographic groups remained. African American-owned firms were more likely to have been denied credit within the last three years, less likely to have their credit needs met, and more likely to have been 
denied credit on the firm's most recent loan. There was also some evidence that these differentials increased with increases in lender market concentration. African American denial rates on lines of credit also increased with increases in lender market concentration. Hispanicand Asian-owned firms also appear to have a higher incidence of unmet credit needs relative to those of white males. Interestingly though, Hispanics and Asians were not actually denied credit at higher rates than white males on their most recent loan, or on any loan within the past three years. Finally, there was some evidence that female denial rates on at least one loan any time within the past three years and unmet credit needs widened with lender market concentration. There was more pervasive evidence that female denial rates on the most recent loan attempt also increased with increases in lender market concentration.

Our final analysis examined the nominal interest rate paid on the firm's most recent loan. Firm financial characteristics and self-reported credit history played only a limited role in determining the loan's interest rate. In contrast, the Dun and Bradstreet credit score, the market index rate at the time of the loan, loan characteristics such as the loan type, whether the loan rate was a fixed versus floating rate, and the amount of funds borrowed were important influences on the initial nominal interest rate paid. These factors were enough to eliminate any univariate differences in interest rates paid across demographic groups. However, even with our full set of explanatory variables, there was evidence that rates paid by African American- and femaleowned firms (but not those owned by Hispanics or Asians) decreased with increases in lender market concentration.

Including observations for all loan types in the same interest rate equation may be problematic. Different types of loans may have different loan underwriting standards and pricing formulae. Consequently, we analyze interest rates on lines of credit separately. The line of credit analysis finds no evidence that interest rates paid by African Americans or females were related to the degree of competition among lenders. However, we do find some evidence that rates paid by Hispanic-owned firms for lines of credit increased with increases in lender-market concentration.

The remainder of the paper is organized as follows: Section II discusses the theoretical foundation of our analysis. Section III discusses the data. Section IV develops the empirical approach. We present our empirical results in section $\mathrm{V}$, and section VI presents our line of credit analyses and results. Conclusions are presented in section VII. 


\section{Theory and Background}

The credit needs of firms, their ability to obtain credit, and the rates they must pay for it, are as varied as the firms themselves and the markets in which they operate. Consider first the financial needs of firms. Younger firms, or firms that operate in growth industries, are more apt to require credit to pay for initial capital investments and expansions than are mature firms and firms operating in mature industries. Larger, or more profitable firms, are likely to have access to larger pools of earnings that can be reinvested in the firm as well as a broader set of credit instruments. Firms that do not have access to trade credit to help maintain an inventory of merchandise or other supplies will have greater need for loans from commercial lenders. In addition, the type of business that a firm engages in will have an important effect on its need for physical and financial capital. The education and managerial experience of the owners of the firm and their personal wealth or family resources may also play a role in a firm's propensity to make use of credit markets. Finally, cultural differences among owners may influence their credit needs.

The ability of firms to obtain credit will also vary widely, based on the perceived riskiness of the loan. Younger firms may represent a greater risk, both because of the lack of a significant credit history, and because younger firms have substantially higher failure rates than more mature firms. The nature of the enterprise will also affect the risk of failure. A dental practice may have a better chance of survival than a pizzeria, for example. The quality of the collateral associated with the enterprise may also play a role in the risk associated with the loan. If there is a robust secondary market for the equipment that will be purchased under the loan agreement, a creditor will be exposed to fewer losses if the borrower defaults on the loan than in the absence of a secondary market. Older firms, larger firms, firms with higher rates of profits and sales, and lower liabilities relative to assets are likely to signal lower risk to lenders. Perhaps more important than the attributes of the business or their owners, the credit history of the firm and its principal owner (late payments on business or personal obligations, whether legal judgements have been levied or whether its owners have declared personal bankruptcy), sends a strong signal to lenders about the risk of repayment. Finally, lenders can buttress information gathered on credit applications with information obtained from credit bureaus, including firm credit risk scores. These scores are based on statistical models of the propensity to repay a loan, given the attributes of the firm and its credit history. Credit scores can be used to decide whether to grant credit and, in some cases, to determine the price that should be charged for that credit. 
Even though lenders have access to a great deal of information about the creditworthiness of applicants, the decision to extend credit necessarily requires the lender to accept a degree of risk. The lender cannot know with certainty whether the loan will be repaid. If the gender, race, or ethnic background of the applicant adds information (by acting as a proxy for additional unobserved risk factors), and the lender uses this information in the loan granting or rate setting process, then the lender is engaging in "statistical" discrimination (Phelps, 1972). Because statistical discrimination has an economic basis, lenders can (in the absence of penalties associated with detection) improve their profits by engaging in this form of discrimination. In contrast, "noneconomic," or prejudicial discrimination, is based solely on lender tastes. As Becker has shown, these tastes will come at a cost. As a result, strong competition should purge discriminators from the market place over time. But more concentrated markets do not exert the same pressure for cost minimization. Thus, in the absence of competition, it may be possible to sustain non-economic discrimination.

In his analysis of prejudicial discrimination, Becker hypothesized that individuals who have a taste for discrimination behave as if they were willing to pay something, either directly or in the form of a reduced income, to indulge those tastes (Becker, 1971, p. 14). In the present context, we can envision a financial institution that would normally loan funds at rate $r$, requiring instead $\mathrm{r}(1+\delta)$, where $\delta$ is the discrimination coefficient, or interest premium that must be charged, in order to compensate for having to associate with the group for which the lender has a distaste. The discriminator will avoid making profitable loans to this group at any rate $r^{*}$ less than $r(1+\delta)$. The higher interest rate faced by the group facing discriminatory treatment implies fewer loans held and perhaps more denied loans and fewer loan applications.

While the above analysis is a simple application to interest rates of Becker's wage discrimination model, much of the literature on consumer credit and mortgage lending finds that interest rates have little flexibility and, therefore, may be the wrong place to look for discrimination (Peterson, 1981; Duca and Rosenthal, 1994). In this setting, lenders may discriminate by "raising the bar" for applicants from affected demographic groups at prevailing interest rates.

Becker recognized that prejudicial behavior raises a firm's costs (or lowers its revenues), so competition should serve to mitigate this type of discrimination in the long run. While many studies in the labor market literature test for an association between competition and the extent of differentials across demographic groups (Comanor, 1973; Haessel and Palmer, 1976; Long, 1976; 
Oster, 1975; Shepherd and Levin, 1973; Cymrot, 1985; Jones and Walsh, 1991; among others), much of the credit market literature instead estimates some variant of the following econometric model:

$$
\mathrm{Y}=\alpha+\gamma \mathrm{D}+\mathrm{X}^{\prime} \beta+\varepsilon
$$

where $\mathrm{Y}$ represents either denial rates or interest rates charged, $\mathrm{X}$ represents a vector of risk (and any other relevant) characteristics, and D represents an indicator variable for demographic group.

The NSSBF data set along with additional data furnished by the Federal Reserve provides us the unique opportunity to investigate the influence of many factors on observed differentials across demographic group. Among those factors included in our $\mathrm{X}$ vector are the financial characteristics of the firm, the credit history of the firm and its principal owner, a credit risk score developed by Dun and Bradstreet, the age, experience, and education of the principal owner as well as a number of other measures and controls. ${ }^{2}$ Then $\gamma$ captures differences in $\mathrm{Y}$ due to all characteristics associated with D not captured in X. These differences may include statistical and prejudicial discrimination, as well as economic differentials not properly accounted for in the $\mathrm{X}$ vector. To the extent that preferences for borrowing vary by demographic group, these differences will also be picked up in $\gamma$. In addition to the above specification, we exploit variation in concentration across banking markets and also estimate econometric models of the following form:

$$
\mathrm{Y}=\alpha+\gamma \mathrm{D}+\gamma^{\prime}\left(\mathrm{D}^{*} \mathrm{HHI}\right)+\mathrm{X}^{\prime} \beta+\varepsilon
$$

Under this specification, $\gamma$ continues to capture group differentials that can arise from a variety of sources that we expect to be invariant to market structure. ${ }^{3}$ In contrast, $\gamma^{\prime}$ reflects differentials associated with lender market concentration. Wider differentials in less competitive lending markets are consistent with Becker's theories of discrimination. We know of only one published paper that examines small business credit market experiences across different demographic groups and lender market concentration. Cavalluzzo and Cavalluzzo (1998) found wide differences in denial rates for African American- and Hispanic-owned firms relative to those of white males. They found no evidence that these differentials were related to lender market

\footnotetext{
${ }^{2}$ For a complete description of the variables included in our model, see Table 3 and Appendix C.

${ }^{3}$ Because of potential concerns with the independence of credit quality and market structure, we examine the relationship between the Dun and Bradstreet credit score (CREDSCR) and the level of bank competition (HHI). Although these variables are correlated, the correlation coefficient is only .0567. A regression model of HHI and CREDSCR predicts that a 100 percentage point increase in the CREDSCR variable (a change that spans the range of CREDSCR) is associated with only a .02132 increase in HHI.
} 
structure. However, they found some evidence that Hispanic-owned firms that were located in concentrated banking markets were less likely to have loans. Hispanic-owned firms located in concentrated markets also paid higher rates than others on the loans that they did have. Interestingly, female-owned firms located in concentrated markets actually paid lower rates than those located in more competitive banking markets. Cavalluzzo and Cavalluzzo found little evidence that other differences across demographic groups were statistically related to lender market structure. However their ability to draw strong conclusions was severely limited by small sample size.

\section{Data and Descriptive Statistics}

Data

We use data from the 1993 National Survey of Small Business Finances (NSSBF) to investigate some of the factors that influence differentials in the credit market experiences of small business operators across different demographic groups. The NSSBF data set is the most extensive public data set available on small businesses. Our sample consists of 4,570 small businesses in operation as of 1993 and includes 1,025 minority-owned businesses (431 African American-, 301 Hispanic-, and 303 Asian-owned), 816 female-owned, and 2,951 firms owned by white-males. ${ }^{4}$

The NSSBF provides us with the firm's age, geographic location, level of employment, 2-digit SIC code, ownership and management characteristics, capital structure, income statement and balance sheet. Several aspects of the credit market experiences of these firms, as well as beliefs about the ability to obtain credit, are also contained in the data. These include whether the firm applied for a loan in the last three years, whether and why the owner believed that its loan request would have been rejected, the terms of the most recent loan the business received, and whether the firm was denied funding, both for the most recent loan application and for anytime within the last three years.

This data set also provides several important new variables on the credit history of the owner, characteristics of the application, and costs of the loan that were not part of the 1987

\footnotetext{
${ }^{4}$ From the original total of 4,637 observations, we drop 35 minority businesses that were owned either by Native Americans or owners of mixed/multiple races, 4 that reported zero assets and 28 others that were missing data on one of several key explanatory variables. Eighteen of these observations were missing credit scores. Additionally, the final sample included 6 firms whose owners were African American and Hispanic, and 4 firms whose owners were Asian and Hispanic.
} 
National Survey of Small Business Finances. These variables include the amount of money requested on the loan application, points and/or fees paid to obtain the loan, the frequency with which the owner reported delinquencies on personal and/or business obligations, whether there were any legal judgements against the firm, whether the owner declared bankruptcy on any business within the past 7 years, and whether the firm had been denied trade credit. We supplement these data with business credit scores for year-end 1993 obtained by the Federal Reserve Board from Dun and Bradstreet. We also include the degree of commercial bank concentration in the business's local credit market. "Local" is defined as the MSA or non-MSA county where the firm's headquarters were located. "Concentration" is based on the continuous Herfindahl-Hirschman index (HHI) for commercial bank deposits in the same local area, and is calculated from the June 1993 Summary of Deposits.

\section{Descriptive Statistics}

The NSSBF data set is a nationwide survey of small businesses (less than 500 employees) that over-sampled large and minority-owned firms. We use weights provided in the NSSBF data set to develop population estimates of the characteristics of firms shown in Tables 1 and 2. The indicators of statistical significance shown in these tables are for a test of differences in means between each demographic group and the white-male subsample. ${ }^{5}$ Variable definitions are provided in Table 3.

Table 1 displays information on the borrowing experiences of small businesses. Numbers in parentheses indicate the number of observations for each subsample and variable. About 64 percent of businesses owned by white-males had loans. Businesses owned by African Americanor Hispanic-males were just as likely to have loans. But female-owned firms, and firms owned by Asian-males were less likely to hold loans. Application rates by demographic group followed a pattern similar to that for loan holdings: African American-male and Hispanic- male small business owners applied at rates similar to that of white-male small business owners. Female and Asian-male small business owners had lower application rates.

We report percentages for two indicators of loan denials. EverDen measures the percentage of small business owners who applied for and were denied credit within the last three years. DenMRL measures the percentage of owners who applied for credit in the last three years

\footnotetext{
${ }^{5}$ Standard errors and statistical significance for these statistics are calculated using 1,000 bootstrap samples. Statistics for minority-female owned businesses should be interpreted cautiously due to small sample size. Cells containing fewer than 16 observations are not reported.
} 
and had their most recent loan application rejected. Table 1 shows that white-males had lower denial rates than most other groups. Businesses owned by African Americans were over twoand-one-half times as likely to be denied credit within the last three years, and almost three times as likely to be denied credit on their most recent loan request than were businesses owned by white-males. Hispanic-male (Asian-male) small business owners were 10.3 (12.72) percentage points more likely to have been denied credit within the last three years, and 2.7 (9) percentage points more likely to have had their most recent loan application rejected than those owned by white-males. Finally, white-male small business owners reported lower interest rates on their most recent loan than owners from every other demographic group. Indeed, small businesses that were owned by African American-males experienced interest rates that were over 99 basis points or 11.1 percent higher than interest rates paid by white-male small business owners. Because the preceding statistics do not control for firm characteristics and credit history, they must be interpreted with care. However, they do suggest that there were some substantial differences in credit experiences among the various demographic groups.

Table 2 provides a variety of descriptive statistics on firm and owner characteristics, credit history, and information on the firm's most recent loan. Characteristics of firms and their owners are contained in Panel A. With the exception of owner age and experience, the data tend to be skewed, as seen in comparisons of the mean and median. Within each subpopulation, there appear to be a few firms that were unusually old, large, more profitable, or with unusually high sales receipts relative to assets, and a few with unusually high debt-to-asset or loan-to-asset ratios.

A number of theories (e.g., Jovanovic, 1982) and empirical studies (e.g., Evans, 1987) suggest that firm behavior changes with firm size. Firms owned by white-males were by far the largest, as measured by total assets. Hispanic-owned firms generated the highest sales and profit figures as a percent of assets, and firms owned by African American-males were somewhat less profitable than those owned by white-males, measured by the median profit-to-asset ratio. Use of the debt-to-asset ratio to evaluate firm risk is widespread among commercial banks (Gibson, 1983). Median debt-to-asset ratios, as well as loan-to-asset ratios, were roughly similar across firms. Asian and African American owners were more educated and Hispanic owners less educated than white-male owners. Minority owners were younger and less experienced than 
white-male owners. Even so, the typical business in our sample is a mature firm with owners who are, on average, middle aged with substantial managerial experience.

Summary statistics on firm credit history are contained in Panel B. The credit history variables indicate that the minority-owned firms, especially those of African Americans, may have been considerably more risky than others. African American small business owners have bankruptcy rates that were at least double those of white-male small business owners. African Americans were also far more likely to be delinquent on personal or business obligations, or to have legal judgements against their firm, than were white-owned small businesses. Dun and Bradstreet credit scores were also higher (indicating superior credit worth) for white-male owned firms than for every other subpopulation, except Asian-females. Finally, Hispanic-male owners were denied trade credit more than twice as frequently as white-male owners, while African American-males were denied trade credit almost three times as often.

Panel C contains information on the characteristics of the most recent loan. Over 80 percent of the most recent small business loans came from commercial banks, and 96 percent came more generally from some financial institution. The high incidence of commercial bank use cuts across demographic groups, although it was lower (but not statistically) for small businesses owned by African American-females and Asian-males. These two groups made more use than others of financing from other businesses. Only 0.75 percent of small business owners borrowed from families and other individuals. Minority women made no use of this source, while less than 3 percent of minority men obtained their recent loan from families or other individuals.

Strong relationships between banks and small businesses have been shown to increase the availability of funds and reduce the cost of capital to small businesses (Petersen and Rajan, 1994; Burger and Udell, 1995). Hispanic small business owners reported longer relationships with their lending institution than white owners, while owners from other minority groups reported substantially shorter relationships with lenders. And, with the exception of Hispanic-women owners, small business owners from all demographic groups were less likely than white-male owners to have received originally desired terms on their most recent loan.

The last two entries in Panel $\mathrm{C}$ are consistent with findings reported by other researchers who have found that small business owners borrow locally (Elliehausen and Wolken, 1990, and Kwast, Starr-McCluer, and Wolken, 1997). Eighty-four percent of the most recently acquired 
loans came from the same city in which the headquarters of the small business resided. Moreover, the median distance between the firm and the loan granting institution was only 3 miles.

\section{Empirical Approach}

\section{Analyses and Dependent Variables}

We analyze four different aspects of the credit market experience to gain a better understanding of possible differences in credit treatment across demographic groups. ${ }^{6}$ These include whether businesses applied for credit, whether they avoided applying because they believed they would be denied, whether those that did apply were denied credit, ${ }^{7}$ and the interest rates firms were charged on their most recent loans.

The first analysis focuses on differences by demographic group on the probability that firms applied for credit. Our dependent variable, Apply equals one if a firm applied for credit within the last three years and zero otherwise. ${ }^{8}$ Ceteris paribus differences in application rates by demographic group may reflect systematic differences in the nature of the firm or industry that are not fully accounted for in other control variables, systematic differences in the risk preferences of owners, differences in use of informal networks (e.g., family) over formal financial markets, and/or feedback effects that may result from discrimination. To the extent that discriminatory practices discourage small business operators from seeking credit, application rates for some groups would be lower, all else equal, in the presence of these effects. Moreover, we would expect feedback effects that arise from non-economic discrimination to be more pronounced in more highly concentrated lending markets.

While considerable conceptual discussion of the influence of feedback effects exists in the literature, there is scant information on the size of such effects. ${ }^{9}$ We examine this aspect of the firm's credit experience by focusing on the firm's reluctance to apply for credit for fear of being turned down. The NSSBF data set provides us with a unique opportunity to investigate the extent to which feedback effects exist for certain demographic groups. Specifically, the NSSBF

\footnotetext{
${ }^{6}$ A fifth analysis that focuses on loans held is contained in Appendix A.

${ }^{7}$ Our denial analyses examine three different dependent variables: 1) whether the firm has been turned down for credit anytime within the past three years, 2) whether the firm has either been turned down for credit or did not apply for fear of being turned down, and 3) whether the firm was turned down on its most recent loan request. Each aspect is discussed, in turn, below.

${ }^{8}$ Loan application dates span the 1990-1994 period. Most of the recent loans were applied for during 1992 and 1993.

${ }^{9}$ Though Cavalluzzo and Cavalluzzo (1998) provide an indirect test for feedback effects.
} 
survey asked all firms, conditional on a need for credit, if during the last three years there were times that the firm did not apply because it thought the application would be turned down. For all firms that expressed a demand for credit sometime over the past three years (either by applying for credit or by not applying for fear of being rejected), we define the variable FearDen, and set it equal to 1 if the firm did not apply for credit, zero otherwise.

The next avenue of analysis focuses on demographic differences in denial rates by lender market structure. Our sample is limited to firms that applied for credit within three years of the survey interview date. The dependent variable, EverDen equals one if a firm was denied credit anytime within the last three years, zero otherwise. One potential shortcoming of the ever denied analysis is that it is subject to feedback effects (Arrow, 1973) because it ignores firms that would have applied for credit but did not for fear of being turned down. If this is the case, the EverDen analysis may understate minority and female access to credit markets. To examine the extent to which this selection process influenced the EverDen analysis, we redefine the EverDen sample to include the additional firms that did not apply for credit over the past three years if they reported that they did not apply because they anticipated that their loan application would have been rejected (Blanchflower, et. al 1998). The dependent variable in this analysis equals one for firms that did not obtain credit (either because they did not apply for fear of denial or because their application was rejected), and zero otherwise (EverDen2). Thus, the additional firms included in this analysis are treated as if they were denied. This variable should more closely capture a firm's unmet credit needs. We also examine a third variable, DenMRL, equal to one if the firm was denied credit on its most recent loan request. The presence of discrimination in the market place does not imply that all creditors discriminate (Becker, 1971). If, as is likely to be the case, only some creditors discriminate against particular classes of borrowers, then their negative effect on access to credit will be reduced (and perhaps fully mitigated) by additional search for funding. While EverDen more closely captures the average presence of discriminators in the market place, DenMRL better approximates the impact on credit access that is caused by discrimination.

Our final analysis focuses on differences in interest rates paid across demographic groups. All else equal, we expect discriminatory creditors to require higher rates from borrowers for which they have a distaste. However, applicants that recognize that the quoted rate exceeds the market rate may apply for credit elsewhere. If discrimination is not omnipresent, borrowers who 
do so will be able to find non-discriminators from which to borrow, and the impact of discrimination on market prices will be reduced. ${ }^{10}$ The dependent variable, IntRate, is the nominal interest rate that the firm paid at the time of issue of the most recent loan. The analysis investigates the possibility that minorities or women pay higher rates than white-males, all else equal. $^{11}$

\section{Model Specifications}

For each aspect of the credit market experiences that we examine, we compare results from five specifications of the model. The first is a baseline model that includes financial characteristics of the firms as well as bivariate demographic indicators, and a HerfindahlHirschman index (HHI) that controls for the degree of commercial bank concentration in the local credit market. ${ }^{12}$ We call this a baseline model because it most closely resembles the type of model that traditionally has been reported in the literature on market discrimination. The second specification augments the first with eight variables on the credit history of the firm and its owner. These data are normally not available to researchers, and are an important potential source of omitted variable bias. Our third specification adds the Dun and Bradstreet credit score to the model (CREDSCR). CREDSCR is a constructed variable that ought to be highly correlated with the credit histories, firm, and financial characteristics already in the model (and, in fact, may add no new information). Rather than mask the importance of these characteristics in a credit score, we chose to add the latter variable, which many lenders use to augment information gathered on loan applications, in a stepwise fashion. Having included the full set of indicators of credit risk, we next include interactions between demographic groups and market concentration in Model 4. Following Becker, this specification provides an opportunity to evaluate inferential evidence of heightened levels of discrimination in highly concentrated

\footnotetext{
${ }^{10}$ Alternatively, discriminators may, because of fear of detection, simply "raise the bar" for particular classes of applicants, driving those applicants to other (nondiscriminatory) lenders. In this case, given risk attributes and market conditions, interest rate differentials may not be observed across demographic groups.

${ }^{11}$ The interest rate models control for, among other things, points and fees paid to close the loan (POINTS, FEE_AMT), whether the loan was fixed or variable (FIXED), maturity (INVMAT), term structure (TERMPREM), a small firm risk premium (BONDSPRD), and the prevailing market interest rate at the time of the loan (MRL_INDX). In these models, length of relationship (REL_JBNK) and firm age (LNAGE2) are adjusted to the loan application date. For details, see Table 3.

${ }^{12} \mathrm{HHI}$ is computed based on FDIC summary of deposit data and ranges from one to 10,000 . We rescale this index, placing it on a zero to one scale to ease interpretability. The rescaled mean value of $\mathrm{HHI}$ in the banking markets used by small businesses in our data set is 0.2018 , and ranges from 0.0661 to 0.8215 in MSAs and from 0.1005 to 1.0 in nonmetropolitan areas.
} 
markets. We call Model 4 the "full specification."13 In a final model, Model 5, we include the bivariate indicator DENTC. Although "denied trade credit" is likely to be affected by credit risk variables already in the model, we include it because both bankers and suppliers of trade credit have an opportunity to meet the small business owner. This personal interaction provides an opportunity for these lenders to gain information about the borrower that may not be available to the researcher.

In a series of robustness checks, we also estimated Models 3 and 4 using several different criteria for sample selection, alternative specifications of lender market concentration and other control variables, and unweighted data. For details, see Appendix B.

\section{Statistical Controls}

Empirical studies that attempt to quantify the effects of discrimination are particularly vulnerable to criticism associated with model specification. Unobservable or omitted variables are especially worrisome since they have the potential to bias estimates of the demographic coefficients that are intended to capture discriminatory practices. One of the strengths of NSSBF data sets is the vast amount of information they contain on both credit market participants and potential participants (that is, firms that chose not to apply for credit). Cavalluzzo and Cavalluzzo (1998) exploit the 1987 data set to make new contributions to the literature on the credit market experiences of small business operators by demographic group. Their conclusions, nevertheless, are limited by the data. They can observe interest rates, but they cannot observe fees that may have been tied to the loan. They know a good deal about the characteristics of the firms and their owners, but they do not have credit histories. In addition, minority samples are small. The 1993 NSSBF data mitigates these drawbacks. Minority samples are substantially larger, loan fees and points paid are provided, and information on firm and owner credit histories are available. We use these data along with information on firm and owner characteristics, financial characteristics of the firm, and firm relationships with lenders and suppliers in our analyses. In addition, we supplement these data with information made available to us by the Board of Governors of the Federal Reserve System on the credit scores assigned to the small businesses in our sample and the level of competition in the credit markets used by these small businesses. Table 3 contains all variable

\footnotetext{
${ }^{13}$ The full set of coefficient estimates for Model 4 (full specification) for each dependent variable is presented in Appendix E.
} 
definitions, in addition to model specifications for each of our analyses. Additional details on the statistical controls are provided in Appendix C.

\section{Results}

Apply Analysis (Apply)

Table 4 presents coefficients from a logit model that estimates the probability that a firm applied for a loan, or loan renewal, "within the last three years" of the interview date. ${ }^{14}$ Apart from Asians, we find no evidence that application rates varied across demographic group. Models 1-3 present results without the HHI interaction terms. Coefficients on all demographic variables, save ASIAN, are statistically insignificant, while those on ASIAN are significant at the one percent level. The coefficient on ASIAN in Model 3 suggests that, all else equal, Asians were less likely to apply for credit than their white-male counterparts by eight percentage points. $^{15}$

If market discrimination reduces the chances that members of particular demographic groups will be able to obtain credit, then it is also possible that these reduced chances will influence the behavior of would-be borrowers from the affected demographic groups. Arrow (1973) calls these second-order effects feedback effects. Models 4 and 5 demonstrate that application rates were not sensitive to lender market structure; all the HHI interaction terms are statistically insignificant. At this point, there is little evidence to suggest that non-economic discrimination dampened owners' propensity to apply for credit.

Firm attributes that were associated with increases in loan application rates include firm size, measured as both the natural log of assets and employment, the ratio of liabilities to assets, the use of trade credit, some college education, and the number of firm relationships with financial institutions. Among credit history variables, only delinquencies on personal obligations were statistically significant. Firms with greater personal delinquencies were statistically less likely to apply for credit.

\footnotetext{
${ }^{14}$ For the applied, denied, and interest rate analyses, length of relationship and age of firm are adjusted to reflect the value of these variables at the time the loan application was made.

${ }^{15}$ The mean predicted probability that a firm owned by a white male applied for credit is 35 percent vs. 27 percent for Asian males. Probability estimates are computed for each observation in the sample, assuming the observation has the characteristic of interest. In this case, they are computed twice, first assuming every observation is a firm owned by an Asian male and second assuming every observation is a firm owned by a white male. Unless otherwise stated, all race and ethnicity point estimates pertain to males and female point estimates refer to firms owned by white females.
} 


\section{Credit needs and application avoidance (FearDen)}

In this section, we examine the factors that determine whether small business owners refrained from applying for credit at least once over the past three years because they anticipated being denied credit. Table 5 presents descriptive statistics on firm demand for credit and owner expectations concerning the ability to obtain credit. Over the past three years, about 50 percent of firms demonstrated a need for credit, either by applying for a loan or reporting that they did not apply because they did not think they would be able to obtain credit. Among all demographic groups, African Americans displayed the greatest desire for credit $(79$ percent for females and 70 percent for males) followed by Hispanics, Whites, and Asians. The relatively low credit needs expressed by Asians is consistent with our previous analysis, which found that Asians were less likely than other groups to have applied for loans. ${ }^{16}$ The relatively high credit needs on the part of African American and Hispanic small business owners, coupled with insignificant differences in loan application rates between these groups and white-males, suggests that these groups were more likely than white-male owners to have had unmet credit needs.

Of the firms that expressed a need for credit, fully half reported that they did not apply for credit sometime within the last three years because they did not expect to be able to get credit. These "fear" rates ranged from between 45 and 50 percent for white-owned businesses, to the low 60s for businesses owned by Hispanic- and Asian-males and the low to mid 80s for African American- and Hispanic female-owned businesses. Looking at the distribution of reasons for believing that their application would be rejected, we find that poor credit history or firm financial conditions were by far the leading reasons, with close to 60 percent of owners citing these explanations. In addition, about 20 (13) percent of African American-males (females) cited prejudice as a reason that they anticipated rejection of a loan application. Few members of other demographic groups cited prejudice.

We use logit analysis to examine the factors that influenced the decision not to apply for a loan because the firm feared denial (Table 6). All else equal, we find that African American- and Hispanic-business owners were far more likely to fear denial than were white-male owners, after controlling for financial characteristics of the firm. Coefficients from Model 1 imply that African American owners were almost 53\% more likely, and that Hispanic owners were almost

${ }^{16}$ The analysis is also consistent with results reported in Appendix A on the propensity to have credit. 
$27 \%$ more likely to have avoided applying for a loan due to fear of denial than were businesses owned by white-males. ${ }^{17}$ Inclusion of credit history controls and the credit score (Models 2, 3) reduces these differences somewhat, but African American owners were still about 37\% more likely, and Hispanic owners were $22.8 \%$ more likely to fear that their application would be rejected, when these variables are taken into account.

A number of factors proved to be important in influencing the firm's fear of being turned down for credit. Among financial characteristics, firms with a larger asset base and those with greater revenues relative to sales were important determinants in a firm's fear of denial. The firm's self-reported credit history variables, and the Dun and Bradstreet credit score also played important roles in influencing a firm's fear of denial.

We add interaction terms between market concentration and demographic variables in Models 4 and 5. While the Hispanic coefficient (HISPAN) is still large and significant, the African American coefficient (AFAM) is now insignificant. But FEMALE interacted with lender market concentration (FML*HHI) is statistically significant. The direction of effect indicates that, as lender markets became more concentrated, female-owned firms were more likely to have avoided applying for a loan because of fear that their application would be rejected. This result will prove to be consistent with results from the loan denial analyses. We now turn to that topic.

\section{Denied Analysis}

In this section, we present denial results for small business applications anytime within the last three years and for the most recent loan application.

\section{Ever Denied (EverDen)}

Our analysis of the determinants of whether the firm was denied credit anytime within the last three years is summarized in Table 7. Looking across specifications reveals the importance of credit history in the ability to obtain financing, and in the estimated size of observed differentials by demographic group. Model 1 , which incorporates 44 control variables, but omits firm and owner credit history, leads to a large and highly significant coefficient for African Americans; these firms were more than twice as likely to be denied credit than their white-male counterparts. The estimated probability that an African American-owned firm would have been

\footnotetext{
${ }^{17}$ In model 1, the predicted probability of not applying for credit at least once over the past three years due to fear of denial for African American (Hispanic) males is 73.36 (60.87) percent vs. 47.98 percent for white males.
} 
denied credit at least once during the last three years is 56.4 percent compared to 27.1 percent for firms owned by white-males. The addition of 8 indicators of credit history reduces the African American coefficient, and the predicted probability of African American-denial rates to 48.80 percent. The addition of the Dun and Bradstreet credit score reduces the predicted probability further to 47.3 percent (Model 3).

Firms owned by Asians were also statistically more likely to have been denied credit than firms owned by white-males. Model 1 suggests that the probability of denial for Asians was 38.3 percent. The inclusion of the credit history variables in subsequent models has little effect on the size of the Asian coefficient, but renders it statistically insignificant.

In all, 5 of the 8 credit history indicators were statistically significant at commonly accepted levels. While it appears that creditors are willing to accept the risk associated with up to two delinquencies on the personal obligations of small business owners, having three or more personal delinquencies increased the probability of being denied from 27 to 45 percent. In contrast, missing one business obligation did not appear to increase the likelihood of being denied credit, but missing a second increased the probability of denial from 28 to 44 percent. The D\&B credit score is also highly significant.

The addition of the HHI interaction terms in Model 4 provides important insights into the treatment of different demographic groups across bank market structure. The coefficient on AFAM now approaches zero, but the interaction of AFAM with HHI is quite large and significant at the five percent level. The coefficient on the interaction between FEMALE and $\mathrm{HHI}$ is positive and significant at the one percent level. Both results indicate that denial rates increased relative to rates for firms owned by white-males as concentration rates rose in small business credit markets. However, the results for African Americans were more tenuous. ${ }^{18}$

Due to the continuous nature of HHI, and the non-linearity of the logit specification, we offer insight into the influence of bank market structure on denial rates by predicting the probability of denial for each observation at the tenth, fiftieth, and ninetieth percentiles of HHI

\footnotetext{
${ }^{18}$ Robustness checks restricting the sample to firms located in MSAs resulted in an insignificant coefficient on the AFAM* HHI interaction term. In contrast, FEMALE interacted with HHI remains consistent for firms located in urban areas. Urban businesses accounted for about 80 percent of the sample. For results from sensitivity tests on Model 4, see Appendix B.
} 
for each demographic group in the sample. ${ }^{19}$ Our estimate of the probability of denial for firms owned by white- and African American-males at the competitive (tenth percentile of the African American-male $\mathrm{HHI}$ distribution) evaluation point $(\mathrm{HHI}=0.085)$ is similar: 0.32 and 0.39 , respectively. In contrast, our estimate of the probability of denial in the least competitive markets $\left(90^{\text {th }}\right.$ percentile of the African American-male $\mathrm{HHI}$ distribution, $\left.\mathrm{HHI}=0.225\right)$ is 0.27 for firms owned by white-males compared to 0.55 for firms owned by African Americans. At the median HHI value for African American-owned firms $(\mathrm{HHI}=0.164)$ the probability of denial for white- and African American-owned firms was 0.29 and 0.48 respectively. ${ }^{20}$

The impact of increasing levels of concentration on loan denial rates is similar for firms owned by females. At the tenth percentile of HHI for females $(\mathrm{HHI}=0.11)$, denial rates were 0.21 for female-owned firms versus 0.31 for firms owned by white-males, while at the ninetieth percentile $(\mathrm{HHI}=0.35)$ the denial rate for female-owned firms was 0.37 versus 0.23 for firms owned by white-males. The estimated denial rate of 0.26 for the median female-owned firm $(\mathrm{HHI}=0.199)$ was similar to that for white-males $(0.28)$.

While the differentials between African American- and female-owned firms located in concentrated markets, and those owned by white-males are large, a possible explanation for the observed differentials is that creditors have access to (and use) information in the application process that is unavailable to the research community. In order to further address concerns regarding omitted variable biases, Model 5 includes information on a firm's ability to obtain credit from suppliers by adding "denied trade credit" to the model. ${ }^{21}$ We define DENTC as one if any supplier denied a firm's request for trade credit, zero otherwise. The coefficient on DENTC, though large and highly significant (Model 5), has little influence on the coefficients of AFAM*HHI or FML*HHI, or their significance levels.

\section{Influence of Selection Bias on Estimated Effects (EverDen2)}

The results of the EverDen analysis indicate that denial rates for African American- and female-small business owners increased with lender market concentration. However, the analysis

\footnotetext{
${ }^{19}$ The Department of Justice and Federal Reserve System use 0.18 as their indicator of a highly concentrated market in their merger analysis, potentially rejecting merger applications in situations which create a Herfindahl index exceeding 0.18 . As such, we also provide estimates of the probability of denial for each demographic group at this level of concentration.

${ }^{20}$ And at the Department of Justice cutoff of 0.18 , the differences in the probability of denial were 0.28 vs. 0.50 for white male- and African American-owned firms, respectively.

${ }^{21}$ Note that this information would also have to be correlated with lender market structure in order for it to have an impact on the results in Model 4.
} 
presented in Section V.B suggested that minority- and female-owned small business operators were less likely to have applied for credit because they anticipated having their loan application rejected. Our analysis of EverDen2, including firms that did not apply for credit for fear of being turned down, attempts to address this selection process. Results are presented in Table 7B. The coefficients in Columns 1-3 suggest that African American-, Hispanic-, and Asian-owned firms are more likely than those owned by white-males to have unmet credit needs. (In contrast the EverDen results only uncovered statistically significant differences for African Americans and, to some extent, Asians). The coefficients on ASIAN are now significant across all specifications. Based on Model 1, African American owners were about $47 \%$ more likely to have unmet credit needs than were similar firms owned by white-males. Hispanic and Asian owned firms were about 23 to 26 percent more likely to have their credit needs unfulfilled. The addition of the eight credit history variables and the Dun \& Bradstreet credit score reduces the differential for African American-owned firms from 22.7 to 16.7 percentage points; however, there was little change in the probability levels for Hispanics and Asians.

Inclusion of the HHI interaction terms (Models 4 and 5) demonstrates that, for firms owned by African Americans and females (but not Hispanics or Asians), the differentials became more pronounced as lender market concentration increased. Estimated probabilities of EverDen2 in concentrated markets for African American firms $(\mathrm{HHI}=0.26)$ were 0.73 compared to 0.47 for businesses owned by white-males. ${ }^{22}$ While the estimated probabilities of EverDen2 were by construction higher than the corresponding denial rates observed in the previous analysis, the difference in the probability levels between African Americans and white-males in each analysis is remarkably similar. The difference in the probability of denial (EverDen) is 29 percentage points compared to 26 percentage points for EverDen2, suggesting that the estimated effect of market structure was largely insensitive to the selection concerns. Unmet credit needs in concentrated markets for female-owned firms $(\mathrm{HHI}=0.35)$ were 58.2 percent compared to 44.6 percent for firms owned by white-males. ${ }^{23}$ The difference between estimated denial rates and unmet credit needs for white-male- and female-owned firms was very similar in the two analyses,

${ }^{22}$ The results for African-American owned businesses varied across the samples used for sensitivity testing (Appendix B). African American interacted with HHI became insignificant when the sample was restricted to urban firms.

${ }^{23}$ These HHI levels reflect the $90^{\text {th }}$ percentiles for African American-male and white female-owned firms respectively. 
equaling about 14 percentage points. Further evidence that selection was invariant to market structure can be seen in the ASIAN interaction terms which are statistically insignificant.

\section{Denied most recent loan (DenMRL)}

Our analysis of the disposition of small business owner's most recent loan application is summarized in Table 8 . Consistent with the results of the previous section, credit history played an important role in the ability of small businesses to obtain financing, and in the size of estimated differentials. Model 1, which incorporates 53 control variables, but omits firm and owner credit history, leads to a large and highly significant coefficient for African Americans. Model 1 suggests that African American denial rates were 32.1 percent compared to 17 percent for white-males. The addition of 8 indicators of credit history reduces the probability of denial for African Americans to 26.2 percent. In all, 5 of the 8 credit history indicators are statistically significant at commonly accepted levels of significance. And, as shown in Model 3, the addition of the Dun and Bradstreet credit score (CREDSCR) reduces the probability of denial for African Americans to 25.5 percent, an amount that is still statistically significant at the one percent level, but which is also 6.6 percentage points lower than the Model 1 estimate.

The addition of the HHI interaction terms in Model 4 again leads to some interesting results. The coefficient on AFAM now approaches zero, and the interaction of African Americans with HHI, though quite large, is statistically insignificant. The coefficient on the female HHI interaction term is large and statistically significant at the one percent level. While female denial rates were similar to those for white-males at the median female HHI $(18.7 \%$ compared to $17.6 \%)$, for firms located in more concentrated markets $(\mathrm{HHI}=0.35)$ denial rates were 29 percent for females compared with 16 percent for white-males. Surprisingly, the interaction between Asian and HHI is negative and significant. Finally, the addition of DENTC (Model 5) does little to dampen the magnitude or significance of the race and gender coefficients. $^{24}$

\footnotetext{
${ }^{24}$ Varying the population of small businesses did not change key results. Coefficients on the interaction between African Americans, females, and HHI were large, positive, and for females, statistically significant at the one percent level. Results using a binary HHI in place of the continuous measure still shared the same sign on the interaction terms, however the reported level of significance was greatly diminished (see Appendix B for details).
} 


\section{Interest Rate Analysis (IntRate)}

Table 9 summarizes our results for the nominal interest rate the firm paid on its most recent loan. ${ }^{25}$ Models 1-3 are robust to the changes in specification. Interest rates did not vary significantly by demographic group. Instead, key determinants were current market interest rates, as embodied in the index of relevant interest rates at the time of the most recent loan (MRL_INDX), the type of loan that was being financed (auto loans had lower rates than others), and whether the loan had a fixed rate (more expensive). Firm attributes that raised rates include increases in the liability to asset ratio (LIABASST), and rejection of a loan application in the last three years (EDENALL). Firms that borrowed more paid lower rates (LNAMTBRR), as did firms that had checking accounts (CHECKING), while firms that borrowed from sources other than financial institutions paid about a percentage point and a half less than others. Inclusion of firm credit history did reveal some statistically significant effects, but including these factors had little impact on other coefficient estimates. ${ }^{26}$

The addition of interaction terms between demographic groups and lender-market concentration has an important impact on our results (Models 4 and 5). Although the firm and market influences discussed above remained robust to the change in specification, there is a dramatic effect on variables tied to market concentration. First, the size of the coefficient on HHI increases and becomes statistically significant. All else equal, firms paid higher interest rates as credit market concentration increased. In addition, African Americans and women paid more than white men, but the rate paid declined as market concentration increased. This finding, though unexpected, is consistent with findings reported for women in Cavalluzzo and Cavalluzzo (1998). Based on coefficients reported for Model 4, African American-small business owners in the most competitive markets $(\mathrm{HHI}=.0847)$ were estimated to pay 1.06 percentage points more than white-male owners, while African American owners in the most concentrated banking markets $(\mathrm{HHI}=0.2245)$ were predicted to pay 0.44 percentage points less than white-males. ${ }^{27} \mathrm{In}$ the median African American market $(\mathrm{HHI}=0.1640)$, rates for African American loans were 21

\footnotetext{
${ }^{25}$ Presented results are based on a weighted least squares regression controlling for the sampling design of the NSSBF data set. We also estimated a two stage Heckman type selection model (1979) with the first stage estimating the probability of having a loan. The correlation of the residuals between the two equations was insignificant suggesting the Heckman correction was unnecessary (Stromsdorfer and Farkas, 1980).

26 A Wald test on the joint significance of the eight credit history variables indicated that the set of variables was statistically insignificant.

${ }^{27}$ Ten percent of African American-owned businesses were in banking markets with HHI equal to 0.0847 or less. Another 10 percent were located in markets with commercial bank concentration levels of 0.2245 or more.
} 
basis points higher than those for white-males. Predictions for females find that women paid about a quarter of a percentage point more than white-males in the most competitive markets in which they owned businesses and almost a full percentage point less in the most concentrated banking markets in which they owned businesses. ${ }^{28}$

The negative coefficients on the HHI interaction terms with African American- and female-owned businesses is unexpected, and there are a number of potential explanations for this phenomenon that we consider. First, it could be the case that though the interaction terms are negative, the overall effect of competition on interest rates charged to minority and femaleowned businesses is positive. That is, it is possible that interest rates for African American- and female-owned businesses increased with lender market concentration, though they increased at a lower rate than they did for businesses owned by white-males. However, for this to be the case, the coefficients on the HHI interaction terms would have had to be smaller in absolute value than the coefficient on the main effect of HHI. This is clearly not the case. A second explanation may come from the fact that in the interest rate analysis, we are only observing successful loan applicants. For example, African American and female business owners with firms located in more concentrated banking markets may have left their local markets and entered more competitive markets in order to obtain a loan. If that is the case, then what we may be observing is that those firms, though located in more concentrated markets, obtain their most recent loan in a relatively more competitive market, and thus ultimately paid a lower risk-adjusted rate than their counterparts that obtained their most recent loan in more concentrated markets.

To test this hypothesis, we examined the extent to which minority and female-owned businesses were more likely to leave their local area to obtain their most recent loan than were businesses owned by white-males. We define the dependent variable LOCAL equal to 1 if the firm's latest loan was obtained within 30 miles of the firm's headquarters, zero otherwise, and regressed this variable on (1) the demographic variables and HHI, and (2) a set of HHI interaction terms to determine the extent to which lender market concentration motivated small

\footnotetext{
${ }^{28}$ The behavior of interest rates across markets and demographic group in our battery of sensitivity tests followed a pattern similar to that in Column 4 of Table 9, but at varying levels of magnitude and statistical significance. Market concentration had a statistically positive effect on interest rates charged across all specifications. While African American- and female-owned businesses paid more than those owned by white males at high levels of competition, their rates declined as concentration increased (see Appendix B for details).
} 
business owners to seek credit outside their local area. ${ }^{29}$ While the evidence did suggest that African Americans and Asians were statistically more likely to leave their local area than were businesses owned by white-males, there was no evidence to suggest that this likelihood increased with market concentration. ${ }^{30} \mathrm{~A}$ third explanation is that the bivariate controls for loan type (line of credit, motor vehicle, etc.) in our interest rate model do not properly adjust for differences in prices associated with these different forms of credit. We address this possibility in Section VI.

\section{Analysis Of Lines Of Credit}

Analyses presented in the previous sections found some evidence consistent with Becker's hypotheses. Lender market concentration appears to hamper the ability of African American- and female-owned firms to obtain financing. However, we found no evidence that interest rates increased with concentration. Indeed, the results from Model 4 above indicate that interest rates on loans received by African American- and female-owned businesses declined with increases in market concentration. We also found little evidence to suggest that market concentration motivated borrowers to look to more competitive markets for loans. However, it is possible that inclusion of all loan types in the interest rate model, without adequately controlling for differences in underwriting and pricing policies for each loan type, may have influenced our estimates. This is a concern for other models as well as the interest rate model.

Lines of credit (LOCs) are the dominant credit instrument used by small businesses, accounting for more than 52 percent of the most recent loans. In this section, we re-estimate all relevant models restricting our analyses to lines of credit. The dependent variables we examine are as follows: whether the firm has a line of credit; whether the firm applied for a line of credit; whether the firm was denied credit on its most recent LOC application; and the interest rate paid on lines of credit. ${ }^{31}$ Rather than present all five of our specifications for each dependent variable, we present only Model 3 or Model 4, depending on whether a Wald test on the set of HHI interaction terms is significant.

\footnotetext{
${ }^{29}$ We estimated these regressions twice, with and without MSA controls. Coefficients on the interaction terms were insensitive to the MSA controls.

${ }^{30}$ We tested the sensitivity of our equation to two alternative definitions of our dependent variable. In particular, we looked at whether the firm was more likely to stay in its local MSA or county, and the distance between a firm and its lending institution. None of these alternative specifications indicated that lender market concentration motivated minority or female owned businesses to obtain loans outside their local MSA or county, or at a greater distance than the firm's headquarters, than businesses owned by white males.

${ }^{31}$ EverDen is excluded from the line of credit analyses due to data limitations.
} 
Results

Line of credit results are presented in Table 10. Column one contains the results from estimating whether a firm has any lines of credit and includes HHI interaction terms. The coefficients on the Hispanic-, Asian-, and female interaction terms are large, negative, and for females, statistically significant at the five percent level. These results contrast with those from a previous analysis which found no differences in the likelihood of having loans due to lender market structure (see Appendix A). At the $90^{\text {th }}$ HHI percentile for female-owned firms, we observe that female-owned firms were about 20 percent less likely to have lines of credit than were firms owned by white-males ( 22 percent versus 28 percent). However, as with all loans, there is no evidence that application rates differed across demographic groups or lender market structure (Column 2), except for Asian owners.

Column 3 presents denial rates for lines of credit. These results are similar to those for all types of loans in that denial rates for African American and female owners, relative to whitemale owners, increased with increases in concentration. Moreover, the statistical significance for the AFAM*HHI interaction term has greatly increased $(\mathrm{p}<0.01)$, while the FML*HHI interaction term becomes significant at the 10 percent level. The coefficient on the AFAM*HHI interaction term suggests that African Americans located in concentrated markets $(\mathrm{HHI}=0.2807$ ) faced line of credit denial rates equal to 0.50 , while businesses owned by white-males faced denial rates equal to 0.14 in markets with similar levels of lender market competition.

The results for the interest rate model are presented in Column 4 . The adjusted $\mathrm{R}^{2}$ for the line of credit model is 0.32 versus 0.22 in the original model including all loans, suggesting that the fit of the model has improved considerably. The interaction terms between female and African American owners and market structure are no longer significant. In addition, the HHI interaction term with African Americans is now positive (although statistically insignificant). For these groups, analysis of a single loan type does not lead us to conclude that interest rates varied by level of competition among lenders. However, when we compare interest rates for lines of credit paid by Hispanic-owned firms, we find that this group paid more as lender market concentration increased. A one percentage point increase in HHI translates into an 11.40 basis point increase in the price Hispanics paid for lines of credit. In the median market for Hispanic owned firms $(\mathrm{HHI}=0.1625)$, Hispanics paid about the same as firms owned by white-males. In 
contrast, Hispanic-owned firms located in the $90^{\text {th }}$ percentile of lender market concentration (HHI $=0.2268$ ) paid 69 basis points higher on lines of credit than their white-male counterparts.

\section{Conclusions}

We investigated the sources of differentials in credit market experiences across small business owners from different demographic groups. Our analyses considered the financial characteristics of each firm, each firm's self-reported credit history, an independently tabulated credit risk score, several indicators of each firms' relationship with suppliers and financial institutions, firm success at obtaining credit from suppliers, the education and experience of the principle owner, the firm's organizational form, industry, region, and whether the firm was located in an MSA. These factors were enough to explain raw differences for one of the credit market experiences we considered (interest rates paid by firms owned by African American and white males). In most cases, however, large differences remained. Furthermore, there was some evidence that the extent of these differences, particularly for African American- and femaleowned firms, varied with lender market concentration.

Our analysis of applications indicated that, apart from Asians, there were no differences in application rates across demographic groups. Asians were less likely to have applied for credit, even after including a broad set of explanatory variables. However, there is no evidence that the Asian differentials were related to lender market structure, suggesting that Asians were less likely to desire credit in general. Results for Asians did not change when we focused on a single credit instrument, lines of credit rather than a heterogeneous set of loans. Important factors that were associated with increases in loan application rates included the use of trade credit, some college education, the number of firm relationships with financial institutions, the ratio of liabilities to assets, and firm size, as measured by both the natural log of assets and employment. In contrast, self-reported credit history variables played a surprisingly limited role in the decision to apply for credit.

The next component of our analysis examined the extent to which certain demographic groups refrained from applying for credit because they believed that their application would have been rejected. Results indicate that African American and Hispanic owners were more likely than white owners to have avoided applying for credit at least once in the last three years, even after including a broad range of explanatory variables. But application avoidance did not vary with lender market concentration. However, female-owned firms were more likely to have 
avoided applying for credit as concentration in lender markets increased. Some firm financial characteristics, firm and owner self-reported credit history, the Dun and Bradstreet credit score, and whether a firm was ever denied credit by suppliers (among other variables) all were associated with a reduction in the propensity to apply for credit for fear of being turned down.

Our next set of analyses examined denial rates. We began by focusing on whether firms were denied credit on a loan anytime over the past three years. Firm and owner self-reported credit history indicators, including whether the owner has declared bankruptcy anytime within the past seven years, whether the owner had been delinquent on three or more personal obligations, whether the owner had been delinquent on two or more business obligations, and whether there were any judgments against the firm all contributed to the probability of having been denied credit. Furthermore, the Dun and Bradstreet credit score, whether the firm had been denied credit from suppliers, and some financial characteristics such as firm assets, were all important in determining a firm's probability of denial. Despite the role played by these important explanatory variables, African American-owned firms still faced substantially higher denial rates than businesses owned by white-males. In an effort to understand better the remaining differential, we included a set of interaction terms with race, ethnicity, and gender and lender market-structure. Consistent with Becker's early theories of discrimination, inclusion of these interaction terms uncovered some evidence that African American- and female-owned firms (but not Hispanic- or Asian-owned firms) were denied credit more frequently as lendermarket concentration increased. These results maintained commonly accepted levels of statistical significance even after including additional African American- and female- interaction terms with a rural/urban market indicator variable or limiting the sample to include only those firms with less than $\$ 10$ million in sales. However, eliminating rural markets from the sample reduced the coefficient on the African American- (but not the female-) HHI interaction term to below commonly accepted levels of statistical significance. It should be pointed out though that removing rural markets from the sample reduced the sample by about 25 percent, eliminated the most concentrated markets from the analysis, and reduced our African American representation by approximately 7 percent. ${ }^{32}$

\footnotetext{
${ }^{32}$ Moreover, after removing rural markets (i.e., the most concentrated markets) from the estimation, evidence that interest rates were statistically related to market concentration vanished.
} 
We buttressed our ever-denied analysis with a measure of a firm's desire to obtain credit. Many of the same factors that played a role in our initial denial analysis were also important in this second set of analyses. In particular, firm and owner credit history, the Dun and Bradstreet credit score, and whether the firm was ever denied credit from suppliers were important determinants of a firm's access to credit markets. Nonetheless, even after including these factors, substantial differentials across some of the demographic variables remained. African AmericanHispanic- and Asian-owned firms were all less likely to have their credit desires met relative to firms owned by white males. Coupled with the results from the applied analysis, which found no evidence of differences in application rates across African American- and Hispanic-owned firms, these results are consistent with the presence of feedback effects as postulated by Arrow (1973). That is, the evidence suggests that application rates for these firms would have been higher than those of white males, but for these effects. Even so, there was no evidence that the Hispanic and Asian differentials varied with lender market concentration. There was some evidence that the differentials for African American- and female-owned firms were related to lender market concentration, however. Coefficients on the interaction terms for these variables were statistically significant at commonly accepted levels in both the full sample and in the sample including only those firms with less than $\$ 10$ million in sales. But coefficient estimates limiting the sample to just MSAs, MSAs and firms with less than $\$ 10$ million in sales, or using a binary $\mathrm{HHI}$ in place of our continuous HHI measure, though positive, were never statistically significant at commonly accepted levels.

The final element of our denial analyses focused on the firm's most recent loan application. Firm and owner credit history, the Dun and Bradstreet credit score, being denied credit from suppliers, and some firm financial characteristics played important roles in the probability of being denied credit on the firm's most recent loan. Nevertheless, large differentials between African American- and white male-owned firms remained. However, in contrast to the previous two sets of denial analyses, which found some evidence that the African American differentials were associated with lender market structure, there was no evidence that this was the case for the most recent loan. We did find evidence that denial rates on the most recent loan for female-owned firms varied with lender market structure, however. Models that included female interacted with HHI were positive and statistically significant in six of the seven estimations presented for this indicator of credit market experience. Additional analysis that 
focused on a single loan type, lines of credit, also found a positive and significant relationship between female denial rates (as well as those for African Americans) and lender market concentration.

Our study concluded with a look at interest rates paid on a heterogeneous set of loans and on one specific type of loan, lines of credit. Raw differentials indicated that only African American males paid statistically higher interest rates than white males. Inclusion of the characteristics of the most recent loan eliminated this differential. Other important factors that influenced the initial nominal interest rate paid included the prevailing market index rate at the time of the loan, a set of variables characterizing the type of loan received, the size of the loan, and whether the interest rate was fixed or floating. In contrast to our set of denial analyses, information on self-reported credit histories played a relatively minor role in determining the nominal interest rate paid on the firm's most recent loan. But this does not mean that interest rate paid did not vary with borrower risk characteristics; the Dun and Bradstreet credit score was statistically related to interest rates paid, with less risky firms paying lower rates. While there were no differences in interest rates across demographic groups prior to including the concentration interaction terms, inclusion of race, ethnicity, and gender interaction terms found evidence that African American- and female-owned firms paid lower rates as lender market concentration increased. Because this result could be caused by the heterogeneous set of loan types contained in the data, we conducted a separate analysis of a single loan type, lines of credit. This analysis found no evidence that African Americans and females paid less as lender market concentration increased. However, evidence emerged that Hispanic-owned firms paid higher interest rates as lender market concentration increased in the lines of credit analysis.

In sum, we find an important role for many of the factors considered in our study of differences in the credit market experiences of small business owners from different demographic groups. In one case, these factors were enough to explain away raw differences. In other cases substantial differences remained. Further analysis indicated, particularly for African American- and female-owned firms, that some of these observed differences were related to lender market structure in a manner consistent with Becker's early theories of discrimination.

It is difficult to determine whether observed differences in credit market experiences across demographic groups are due to discrimination. We attempted to understand the sources of observed differentials by examining a broad set of firm and owner characteristics, along with 
information on the competitiveness of the local banking market. However, in many of the cases we examined, substantial differences remained. We recognize that research of the type presented here always suffers from limitations of various sorts. Nonetheless, we believe documenting the existence of differences in credit market experiences, providing a framework for analyzing those differences, and identifying potential reasons for the differences is an important step in increasing our understanding of small business credit markets. 


\section{REFERENCES}

Andrews, D. F., et al. Robust Estimates of Location: Survey and Advances. Princeton: Princeton University Press, 1972.

Arrow, Kenneth J. “The Theory of Discrimination.” In Discrimination in Labor Markets, edited by Orley Ashenfelter and Albert Rees, 3-34. Princeton: Princeton University Press, 1973

Barefoot, Jo Ann. "Must Lenders Prove They Don't Discriminate?" A. B. A. Banking Journal 82 (August 1990): 32, 36.

Bates, T. "Commercial Bank Financing of White- and Black-Owned Small Business Start-ups." Quarterly Review of Economics and Business 31 (Spring 1991): 64-80.

Becker, Gary S. The Economics of Discrimination. 2d ed. Chicago: University of Chicago Press, 1971.

—. "The Evidence Against Banks Doesn’t Prove Bias." Business Week, 19 April 1993, 18.

Berger, Allen, and Gregory Udell. "Relationship Lending and Lines of Credit in Small Firm Finance." Journal of Business 68, no. 3 (1995): 351-381.

Berkovec, J., et al. "Race, Redlining, and Residential Mortgage Loan Performance." Journal of Real Estate, Finance, and Economics 9 (November 1994): 263-294.

—_. "Discrimination, Default, and Loss in FHA Mortgage Lending." Division of Research and Statistics, Board of Governors of the Federal Reserve System, Washington D.C., July 1995.

—_ "Discrimination, Competition, and Loan Performance in FHA Mortgage Lending." Review of Economics and Statistics 80 (May 1998): 241-250.

Black, Harold, Robert Schweitzer, and Lewis Mandell. "Discrimination in Mortgage Lending." American Economic Review 68 (May 1978): 186-91.

Blanchflower, D. G., P. B. Levine, and D. J. Zimmerman. "Discrimination in the Small Business Credit Market." Working Paper W6840. New York: National Bureau of Economic Research, December 1998.

Cavalluzzo, Ken, and Linda Cavalluzzo. "Market Structure and Discrimination: The Case of Small Businesses." Journal of Money, Credit, and Banking 30 (November 1998): 771-792.

Cavalluzzo, Ken, and Christopher Géczy. "Agency, Financing, Liability and Taxes: The Choice of Organizational Form." McDonough School of Business, Georgetown University, Washington, D.C., March 1998. 
Cole, Rebel A. "Availability of Credit to Small and Minority-Owned Businesses: New Evidence from a National Survey." Division of Research and Statistics, Board of Governors of the Federal Reserve System, Washington, D.C., 1997.

Comanor, W. "Racial Discrimination in American Industry." Economica 40 (November 1973): 363-378.

Cymrot, Donald J. “Does Competition Lessen Discrimination? Some Evidence.” Journal of Human Resources 20 (Fall 1985): 605-612.

Dennis, W., W. Dunkelberg, and J. Van Hulle. Small Business and Banks: The United States. Washington, D.C.: The N. F. I. B. Foundation, 1988.

Duca, John V., and Stuart S. Rosenthal. "Borrowing Constraints, Household Debt, and Racial Discrimination in Loan Markets." Journal of Financial Intermediation 3 (1993): 77-103.

—. "Do Mortgage Rates Vary Based on Household Default Characteristics? Evidence on Rate Sorting and Credit Rationing." Journal of Real Estate Finance and Economics 8 (1994): 99-113.

Elliehausen, Gregory E., and John D. Wolken. "Banking Markets and the Use of Financial Services by Small and Medium-Sized Businesses." Federal Reserve Bulletin 76 (October 1990): 801-817.

Evans, D. "Tests of Alternative Theories of Firm Growth." Journal of Political Economy 95 (August 1987): 657-674.

Fama, Eugene, and Michael Jensen. “Agency Problems and Residual Claims.” Journal of Law and Economics 26 (June 1983): 327-349.

Foster, George. Financial Statement Analysis. 2d ed. Englewood Cliffs, New Jersey: PrenticeHall, 1986.

Ferguson, M. F., and S. R. Peters. "What Constitutes Evidence of Discrimination in Lending?" The Journal of Finance 50 (June 1995): 739-748.

Gibson, C. "Financial Ratios as Perceived by Commercial Loan Officers." Akron Business and Economic Review, (Summer 1983): 23-27.

Goldberg, Matthew S. "Discrimination, Nepotism, and Long-Run Wage Differentials." The Quarterly Journal of Economics 97 (May 1982): 307-319.

Greene, William H. Econometric Analysis. New York: Macmillan, 1993.

Haessel, Walter P., and John W. Palmer. "Market Power and Employment Discrimination." Journal of Human Resources 13 (Fall 1978): 545-560. 
Heckman, J. J. "Sample Bias as a Specification Error." Econometrica 47 (January 1979): 153161.

Hunter, William, and Mary Beth Walker. "The Cultural Affinity Hypothesis and Mortgage Lending Decisions." Issues in Financial Regulation 95-8. Federal Reserve Bank of Chicago, July 1995.

Jones, J., and W. D. Walsh. "Product Market Imperfections, Job Content Differences and Gender Employment Discrimination at the Management Level: Some Evidence from the Canadian Manufacturing Sector in 1971 and 1981." Canadian Journal of Economics 24 (November 1991): 844-858.

Jovanovic, Boyan. "Selection and the Evolution of Industry." Econometrica 50 (May 1982): 649-670.

King, Thomas A. "Discrimination in Mortgage Lending: A Study of Three Cities." Working Paper 91. Washington, D.C.: Federal Home Loan Bank Board, 1980.

Kwast, Myron, Martha Starr-McCluer, and John D. Wolken. "Market Definition and Antitrust in Banking." The Antitrust Bulletin 42 (Winter 1997): 973-995.

Long, J. E. "Employment Discrimination in the Federal Sector." Journal of Human Resources 11 (Winter 1976): 86-97.

Maddala, G. S. Limited-Dependent and Qualitative Variables in Econometrics. Cambridge: Cambridge University Press, 1983.

Mansfield, E. "Entry, Gibrat's Law, Innovation, and the Growth of Firms." American Economic Review 52 (1962): 1023-1051.

Munnell, A., L. Browne, J. McEneaney, and G. Tootell. "Mortgage Lending in Boston: Interpreting HMDA Data." American Economic Review 86 (March 1996): 25-53.

Myers, S., and N. Majluf. "Corporate Financing and Investment Decisions When Firms Have Information That Investors Do Not Have." Journal of Financial Economics 13 (June 1984): 187-221.

Neumark, D. "Employers' Discriminatory Behavior and the Estimation of Wage Discrimination." Journal of Human Resources 23 (Summer 1988): 279-295.

Oster, S. "Industry Differences in the Level of Discrimination Against Women." Quarterly Journal of Economics 89 (May 1975): 215-229.

Oaxaca, R. "Male, Female Wage Differentials in Urban Labor Markets." International Economic Review 14 (October 1973): 693-709. 
Oaxaca, R., and M. R. Ransom. "On Discrimination and the Decomposition of Wage Differentials." Journal of Econometrics 61 (March 1994): 5-21.

Petersen, M., and Rajan, R. "The Benefits of Lending Relationships: Evidence from Small Business Data." Journal of Finance 49 (March 1994): 3-37.

— . "The Effect of Credit Market Competition on Lending Relationships." Quarterly Journal of Economics 110 (May 1995): 407-443.

Peterson, Richard L. "An Investigation of Sex Discrimination in Commercial Banks' Direct Consumer Lending." Bell Journal of Economics 12 (Autumn 1981): 547-561.

Phelps, E. S. "The Statistical Theory of Racism and Sexism." American Economic Review 62 (September 1972): 659-661.

Price Waterhouse LLP. "National Survey of Small Business Finances Methodology Report." Board of Governors of the Federal Reserve System, Washington, D.C., 24 July 1996.

Quigley, John M. "Mortgage Performance and Housing Market Discrimination." Cityscape: A Journal of Policy Development and Research 2 (February 1996): 59-64.

Riley, John G. "Credit Rationing: A Further Remark." American Economic Review 77 (March 1987): 224-227.

Schafer, Robert, and Helen F. Ladd. Discrimination in Mortgage Lending. MIT-Harvard Joint Center for Urban Studies. Cambridge: MIT Press, 1981.

Selz, M. "Race-Linked Gap is Wide in Business Loan Recipients.” Wall Street Journal, 6 May 1996, B2.

Shepherd, W. G., and S. C. Levin. "Managerial Discrimination in Large Firms." Review of Economics and Statistics 55 (November 1973): 412-422.

Stiglitz, Joseph E., and Andrew Weiss. "Credit Rationing in Markets with Imperfect Information." American Economic Review 71 (June 1981): 393-410.

Stromsdorfer, E., and G. Farkas, eds. Evaluation Studies Review Annual. Vol. 5. Beverly Hills, California: Sage Publications, 1980.

Welch, F. "Black-White Differences in Returns to Schooling." American Economic Review 63 (December 1973): 893-907.

Yinger, John. "Why Default Rates Cannot Shed Light on Mortgage Discrimination." Cityscape: A Journal of Policy Development and Research 2 (February 1996): 25-31. 
Table 1: Borrowing Characteristics of Small Businesses by Demographic Group - Population Estimates

Means $(\mathrm{N})$

\begin{tabular}{|c|c|c|c|c|c|c|c|c|c|}
\hline & \multirow[t]{2}{*}{ All } & \multicolumn{2}{|c|}{ White } & \multicolumn{2}{|c|}{ African American } & \multicolumn{2}{|c|}{ Hispanic } & \multicolumn{2}{|c|}{ Asian } \\
\hline & & Males & Females & Males & Females & Males & Females & Males & Females \\
\hline Percent with loans (Loan) & $\begin{array}{c}62.24 \\
(4,570)\end{array}$ & $\begin{array}{c}63.70 \\
(2,951)\end{array}$ & $\begin{array}{c}58.55^{*} \\
(594)\end{array}$ & $\begin{array}{l}64.50 \\
(336)\end{array}$ & $\begin{array}{c}51.39 * \\
(95)\end{array}$ & $\begin{array}{l}63.20 \\
(236)\end{array}$ & $\begin{array}{c}53.08 \\
(65)\end{array}$ & $\begin{array}{c}54.48^{*} \\
(238)\end{array}$ & $\begin{array}{c}47.35 * \\
(65)\end{array}$ \\
\hline Percent applied (Apply) & $\begin{array}{c}34.50 \\
(4,570)\end{array}$ & $\begin{array}{l}35.95 \\
(2,951)\end{array}$ & $\begin{array}{l}31.55 \\
(594)\end{array}$ & $\begin{array}{l}36.71 \\
(336)\end{array}$ & $\begin{array}{c}28.09 \\
(95)\end{array}$ & $\begin{array}{l}35.96 \\
(236)\end{array}$ & $\begin{array}{l}12.67 * \\
(65)\end{array}$ & $\begin{array}{c}25.86^{*} \\
(238)\end{array}$ & $\begin{array}{c}16.97 * \\
(65)\end{array}$ \\
\hline $\begin{array}{l}\text { Percent denied within last } \\
\text { three years (EverDen) }\end{array}$ & $\begin{array}{c}28.67 \\
(1,985)\end{array}$ & $\begin{array}{c}26.04 \\
(1,418)\end{array}$ & $\begin{array}{l}30.33 \\
(225)\end{array}$ & $\begin{array}{c}68.54^{*} \\
(134)\end{array}$ & $\begin{array}{c}52.46^{*} \\
(31)\end{array}$ & $\begin{array}{c}36.29 \\
(82)\end{array}$ & $\begin{array}{c}33.72 \\
(16)\end{array}$ & $\begin{array}{c}38.76 \\
(66)\end{array}$ & - \\
\hline $\begin{array}{l}\text { Percent denied on most } \\
\text { recent loan }(\text { DenMRL })\end{array}$ & $\begin{array}{c}18.45 \\
(1,985)\end{array}$ & $\begin{array}{c}16.01 \\
(1,418)\end{array}$ & $\begin{array}{l}22.99 \\
(225)\end{array}$ & $\begin{array}{l}49.15^{*} \\
(134)\end{array}$ & $\begin{array}{c}37.26^{*} \\
(31)\end{array}$ & $\begin{array}{l}18.72 \\
(82)\end{array}$ & $\begin{array}{l}12.62 \\
(16)\end{array}$ & $\begin{array}{c}25.01 \\
(66)\end{array}$ & - \\
\hline $\begin{array}{l}\text { Average interest rate on } \\
\text { most recent loan (IntRate) }\end{array}$ & $\begin{array}{c}8.77 \\
(1,682)\end{array}$ & $\begin{array}{c}8.72 \\
(1,265)\end{array}$ & $\begin{array}{c}8.78 \\
(189)\end{array}$ & $\begin{array}{l}9.71 * \\
(70)\end{array}$ & $\begin{array}{l}9.27 \\
(18)\end{array}$ & $\begin{array}{l}9.13 \\
(68)\end{array}$ & - & $\begin{array}{l}9.03 \\
(52)\end{array}$ & - \\
\hline
\end{tabular}

\section{NOTES}

1. Population estimates weighted to reflect differences in sample selection and response rates (see Price Waterhouse LLP, 1996).

2. An $*$ signifies that the statistic is significantly different from the white-male-owned firm value at the $95 \%$ level of confidence. Standard errors for these tests are calculated using 1,000 bootstrap sample and weight replicates.

3. A "-“"signifies that statistics were not reported because the sample size $(\mathrm{N})$ was 15 or less. 
Table 2 - Descriptive Statistics: Means (Medians)

\begin{tabular}{|c|c|c|c|c|c|c|c|c|c|}
\hline & \multirow[t]{2}{*}{ All } & \multicolumn{2}{|c|}{ White } & \multicolumn{2}{|c|}{ African American } & \multicolumn{2}{|c|}{ Hispanic } & \multicolumn{2}{|c|}{ Asian } \\
\hline & & Males & Females & Males & Females & Males & Females & Males & Females \\
\hline \multicolumn{10}{|c|}{ Panel A: Firm and Owner Characteristics } \\
\hline Assets $(000)$ & $\begin{array}{l}490 \\
(70)\end{array}$ & $\begin{array}{l}590 \\
(80)\end{array}$ & $\begin{array}{l}220^{*} \\
(50)^{*}\end{array}$ & $\begin{array}{l}190 * \\
(50)^{*}\end{array}$ & $\begin{array}{c}90 * \\
(20)^{*}\end{array}$ & $\begin{array}{l}370 \\
(60)\end{array}$ & $\begin{array}{l}140 * \\
(30)^{*}\end{array}$ & $\begin{array}{l}410 * \\
(70)\end{array}$ & $\begin{array}{l}340 \\
(60)\end{array}$ \\
\hline Sales/assets & $\begin{array}{c}6.16 \\
(2.96)\end{array}$ & $\begin{array}{c}6.24 \\
(2.99)\end{array}$ & $\begin{array}{c}5.94 \\
(2.88)\end{array}$ & $\begin{array}{c}6.01 \\
(2.78)\end{array}$ & $\begin{array}{c}5.96 \\
(2.61)\end{array}$ & $\begin{array}{c}5.66 \\
(3.18)\end{array}$ & $\begin{array}{c}8.85 \\
(3.72)\end{array}$ & $\begin{array}{c}6.03 \\
(3.00)\end{array}$ & $\begin{array}{l}3.59 * \\
(2.20)\end{array}$ \\
\hline Profit/assets & $\begin{array}{c}0.97 \\
(0.21)\end{array}$ & $\begin{array}{c}1.01 \\
(0.21)\end{array}$ & $\begin{array}{c}0.80 \\
(0.19)\end{array}$ & $\begin{array}{c}0.75 \\
(0.19)\end{array}$ & $\begin{array}{c}0.91 \\
(0.04)^{*}\end{array}$ & $\begin{array}{c}1.09 \\
(0.59)^{*}\end{array}$ & $\begin{array}{c}1.30 \\
(0.46)\end{array}$ & $\begin{array}{l}1.25 \\
(0.28)\end{array}$ & $\begin{array}{l}0.37 * \\
(0.07)\end{array}$ \\
\hline Debt/assets & $\begin{array}{c}0.63 \\
(0.47)\end{array}$ & $\begin{array}{c}0.62 \\
(0.48)\end{array}$ & $\begin{array}{c}0.61 \\
(0.47)\end{array}$ & $\begin{array}{c}0.93 \\
(0.48)\end{array}$ & $\begin{array}{c}0.69 \\
(0.43)\end{array}$ & $\begin{array}{c}0.58 \\
(0.43)\end{array}$ & $\begin{array}{c}0.71 \\
(0.50)\end{array}$ & $\begin{array}{c}0.72 \\
(0.50)\end{array}$ & $\begin{array}{l}0.47 * \\
(0.41)\end{array}$ \\
\hline Loan/assets & $\begin{array}{c}0.40 \\
(0.25)\end{array}$ & $\begin{array}{c}0.41 \\
(0.26)\end{array}$ & $\begin{array}{c}0.38 \\
(0.23)\end{array}$ & $\begin{array}{c}0.38 \\
(0.20)\end{array}$ & $\begin{array}{c}0.43 \\
(0.21)\end{array}$ & $\begin{array}{c}0.38 \\
(0.21)\end{array}$ & $\begin{array}{c}0.44 \\
(0.25)\end{array}$ & $\begin{array}{c}0.39 \\
(0.30)\end{array}$ & $\begin{array}{c}0.33 \\
(0.13)\end{array}$ \\
\hline \multirow[b]{2}{*}{ Firm age (years) } & 14.34 & 15.26 & $12.42 *$ & $12.64 *$ & $10.22 *$ & $12.62 *$ & $10.75 *$ & $9.24 *$ & $11.26^{*}$ \\
\hline & (11) & $(12)$ & $(9)^{*}$ & $(10)^{*}$ & $(7)^{*}$ & $(10)^{*}$ & $(8)^{*}$ & $(8)^{*}$ & (9) \\
\hline Owner age (years) & $\begin{array}{c}49.46 \\
(48)\end{array}$ & $\begin{array}{c}50.16 \\
(49)\end{array}$ & $\begin{array}{c}47.91 * \\
(46)^{*}\end{array}$ & $\begin{array}{c}49.56 \\
(48)\end{array}$ & $\begin{array}{c}46.74 * \\
(44)^{*}\end{array}$ & $\begin{array}{c}47.49^{*} \\
(47)\end{array}$ & $\begin{array}{c}45.50 * \\
(45)\end{array}$ & $\begin{array}{c}45.83^{*} \\
(45)^{*}\end{array}$ & $\begin{array}{c}48.18 \\
(46)\end{array}$ \\
\hline Owner experience (years) & $\begin{array}{c}18.93 \\
(17)\end{array}$ & $\begin{array}{c}20.37 \\
(19)\end{array}$ & $\begin{array}{c}15.29 * \\
(14)^{*}\end{array}$ & $\begin{array}{c}16.75^{*} \\
(15)^{*}\end{array}$ & $\begin{array}{c}12.54 * \\
(10)^{*}\end{array}$ & $\begin{array}{c}16.15^{*} \\
(15)^{*}\end{array}$ & $\begin{array}{c}12.88^{*} \\
(10)^{*}\end{array}$ & $\begin{array}{c}14.51 * \\
(14)^{*}\end{array}$ & $\begin{array}{c}15.11^{*} \\
(14)^{*}\end{array}$ \\
\hline Percent not finishing high school & 4.49 & 4.72 & $2.20 *$ & 3.92 & $1.19 *$ & $12.18 *$ & 5.37 & 5.48 & 3.38 \\
\hline Percent with some college & 71.99 & 71.50 & 73.48 & $79.90 *$ & $87.85^{*}$ & $61.40^{*}$ & $49.09 *$ & $81.59 *$ & $85.32 *$ \\
\hline
\end{tabular}

\section{NOTES:}

1. An * signifies that the statistic is significantly different from the white-male-owned firm value at the $95 \%$ level of confidence. Standard errors for these tests are calculated using 1,000 bootstrap sample and weight replicates. 


\begin{tabular}{|c|c|c|c|c|c|c|c|c|c|}
\hline & \multirow[t]{2}{*}{ All } & \multicolumn{2}{|c|}{ White } & \multicolumn{2}{|c|}{ African American } & \multicolumn{2}{|c|}{ Hispanic } & \multicolumn{2}{|c|}{ Asian } \\
\hline & & Males & Females & Males & Females & Males & Females & Males & Females \\
\hline \multicolumn{10}{|l|}{ Panel B: Credit History } \\
\hline $\begin{array}{l}\text { Percent declared bankruptcy } \\
\text { within past } 7 \text { years }\end{array}$ & 2.20 & 2.27 & 1.45 & $5.33^{*}$ & 4.40 & 1.40 & 5.03 & 2.53 & $0.00^{*}$ \\
\hline $\begin{array}{l}\text { Percent delinquent on personal } \\
\text { obligations ( } 3 \text { or more times) }\end{array}$ & 8.02 & 7.25 & 7.60 & $22.41 *$ & $17.67 *$ & 12.02 & $26.33^{*}$ & $4.17 *$ & 10.70 \\
\hline $\begin{array}{l}\text { Percent delinquent on business } \\
\text { obligations ( } 3 \text { or more times) }\end{array}$ & 11.71 & 10.90 & 13.68 & $19.75^{*}$ & 14.65 & 16.68 & 12.43 & 7.81 & 7.03 \\
\hline Percent with judgements & 4.91 & 4.48 & 3.96 & $14.80^{*}$ & $15.50^{*}$ & 7.72 & 14.58 & 6.44 & $0.00^{*}$ \\
\hline $\begin{array}{l}\text { D \& B Credit Score } \\
\text { (Range: } 1-100)\end{array}$ & $\begin{array}{c}50.12 \\
(47)\end{array}$ & $\begin{array}{c}51.81 \\
(50)\end{array}$ & $\begin{array}{l}47.57 * \\
(41)^{*}\end{array}$ & $\begin{array}{l}35.86 * \\
(31)^{*}\end{array}$ & $\begin{array}{l}42.15^{*} \\
(39)^{*}\end{array}$ & $\begin{array}{l}43.66^{*} \\
(39)^{*}\end{array}$ & $\begin{array}{l}45.00 \\
(39)^{*}\end{array}$ & $\begin{array}{l}44.63 * \\
(39)^{*}\end{array}$ & $\begin{array}{c}52.77 \\
(50)\end{array}$ \\
\hline Percent denied trade credit & 6.13 & 5.27 & 7.09 & $14.94 *$ & 9.82 & $11.74 *$ & 5.41 & 8.11 & 5.55 \\
\hline \multicolumn{10}{|l|}{ Panel C: Most Recent Loan } \\
\hline Percent from commercial bank & 80.58 & 81.23 & 79.86 & 75.36 & 63.02 & 82.35 & 79.78 & 68.99 & - \\
\hline $\begin{array}{l}\text { Percent from financial institution } \\
\text { (including commercial banks) }\end{array}$ & 95.97 & 95.87 & 98.18 & 91.79 & 84.10 & 94.22 & $100.00 *$ & 90.61 & - \\
\hline $\begin{array}{l}\text { Percent from government } \\
\text { institution }\end{array}$ & 0.51 & 0.31 & 0.61 & $3.95^{*}$ & 5.89 & 1.23 & 0.00 & 1.31 & - \\
\hline Percent from other businesses & 2.78 & 3.12 & $0.77 *$ & 1.99 & 10.02 & 1.67 & $0.00 *$ & 8.08 & - \\
\hline Percent from family or individuals & 0.75 & 0.70 & 0.44 & 2.27 & $0.00 *$ & 2.88 & $0.00 *$ & $2.91 *$ & - \\
\hline $\begin{array}{l}\text { Length of relationship with } \\
\text { institution at time of application }\end{array}$ & $\begin{array}{c}6.80 \\
(4)\end{array}$ & $\begin{array}{l}7.28 \\
(5)\end{array}$ & $\begin{array}{l}4.96^{*} \\
(3)^{*}\end{array}$ & $\begin{array}{l}4.80 * \\
(3)^{*}\end{array}$ & $\begin{array}{l}2.78 * \\
(2)^{*}\end{array}$ & $\begin{array}{c}8.36 \\
(5)\end{array}$ & $\begin{array}{c}8.69 \\
(8)\end{array}$ & $\begin{array}{l}4.70 * \\
(3)^{*}\end{array}$ & $\begin{array}{l}- \\
-\end{array}$ \\
\hline $\begin{array}{l}\text { Percent receiving less desirable } \\
\text { terms than originally requested }\end{array}$ & 9.40 & 8.41 & 11.95 & $20.12 *$ & 14.07 & 14.05 & - & 13.03 & - \\
\hline $\begin{array}{l}\text { Percent not applying fearing } \\
\text { denial }\end{array}$ & 24.37 & 22.30 & 22.45 & $58.81 *$ & $68.05^{*}$ & $38.26^{*}$ & $48.20 *$ & 25.60 & 26.80 \\
\hline $\begin{array}{l}\text { Percent of firms located in } \\
\text { concentrated banking markets }\end{array}$ & 50.61 & 51.23 & 55.13 & $37.67 *$ & 44.38 & $37.63 *$ & 42.60 & $39.16^{*}$ & 41.26 \\
\hline $\begin{array}{l}\text { Percent with most recent loan } \\
\text { institution in same city }\end{array}$ & 84.13 & 84.91 & 82.98 & 82.86 & 74.83 & 82.04 & $100.00 *$ & $67.04 *$ & - \\
\hline Distance (miles) between firm and & 50.68 & 45.81 & 57.73 & 46.26 & 78.08 & $22.27 *$ & - & 234.54 & - \\
\hline institution with most recent loan & $(3)$ & $(3)$ & $(2)$ & $(4)$ & $(9)$ & $(4)$ & - & $(6)$ & - \\
\hline
\end{tabular}

1. An * signifies that the statistic is significantly different from the white-male-owned firm value at the $95 \%$ level of confidence. Standard errors for these tests are calculated using 1,000 bootstrap sample and weight replicates.

2. A “-" signifies that statistics were not reported because the sample size $(\mathrm{N})$ was 15 or less. 
Table 3

Variable Definitions and Model Specifications

\begin{tabular}{|c|c|c|c|c|c|c|c|c|}
\hline Variables & Definitions & \multicolumn{7}{|c|}{ Analysis ${ }^{\mathrm{a}}$} \\
\hline Dependent Variables & & (1) & (2) & (3) & (4) & (5) & (6) & (7) \\
\hline Loan (see Appendix) & $\begin{array}{l}\text { Indicates whether the firm had at least one line of credit, equipment, motor vehicle, capital lease, } \\
\text { mortgage, or other loans. }\end{array}$ & $\mathrm{X}$ & & & & & & \\
\hline Apply & $\begin{array}{l}\text { Indicates whether during the last three years the firm applied for credit or asked for a renewal of } \\
\text { terms on an existing loan. }\end{array}$ & & $\mathrm{X}$ & & & & & \\
\hline FearDen & $\begin{array}{l}\text { Indicates whether there were times in the last three years that the firm did not apply because it } \\
\text { thought it would be turned down. Defined only over those firms that either applied for credit in the } \\
\text { past } 3 \text { years, or did not apply for fear of denial. }\end{array}$ & & & $\mathrm{X}$ & & & & \\
\hline EverDen & $\begin{array}{l}\text { Indicates whether any lender turned down a request for credit from the firm within the last three } \\
\text { years. Defined only for those firms that applied for credit in the past } 3 \text { years. }\end{array}$ & & & & $\mathrm{X}$ & & & \\
\hline EverDen2 & $\begin{array}{l}\text { Equal to one if the firm was ever denied credit or did not apply for fearing denial, zero otherwise. } \\
\text { Defined only for those firms that either applied for credit in the past } 3 \text { years, or did not apply for } \\
\text { fear of denial. }\end{array}$ & & & & & $\mathrm{X}$ & & \\
\hline DenMRL & $\begin{array}{l}\text { Indicates whether the firm was denied its most recent loan request. Defined only for those firms } \\
\text { that applied for credit in the past } 3 \text { years. }\end{array}$ & & & & & & $\mathrm{X}$ & \\
\hline IntRate & Initial nominal interest rate on the firm's most recent loan. & & & & & & & $\mathrm{X}$ \\
\hline \multicolumn{9}{|l|}{ Firm Characteristics } \\
\hline LIABASST & Total short and long term debts / Total assets. & $\mathrm{X}$ & $\mathrm{X}$ & $\mathrm{X}$ & $\mathrm{X}$ & $\mathrm{X}$ & $\mathrm{X}$ & $\mathrm{X}$ \\
\hline PROFASST & Operating Profits / Total assets. & $\mathrm{X}$ & $\mathrm{X}$ & $\mathrm{X}$ & $\mathrm{X}$ & $\mathrm{X}$ & $\mathrm{X}$ & $\mathrm{X}$ \\
\hline LNASSET & Natural log of total assets (in millions of dollars). & $\mathrm{X}$ & $\mathrm{X}$ & $\mathrm{X}$ & $\mathrm{X}$ & $\mathrm{X}$ & $\mathrm{X}$ & $\mathrm{X}$ \\
\hline LNTOTEMP & Natural log of the total number of employees. & $\mathrm{X}$ & $\mathrm{X}$ & $\mathrm{X}$ & $\mathrm{X}$ & $\mathrm{X}$ & $\mathrm{X}$ & $\mathrm{X}$ \\
\hline SALEASST & 1992 Sales / Total assets. & $\mathrm{X}$ & $\mathrm{X}$ & $\mathrm{X}$ & $\mathrm{X}$ & $\mathrm{X}$ & $\mathrm{X}$ & $\mathrm{X}$ \\
\hline LNAGE & Natural log of firm age at the time of the survey. & $\mathrm{X}$ & $\mathrm{X}$ & $\mathrm{X}$ & & & & \\
\hline LNAGE2 & $\begin{array}{l}\text { Natural log of firm age at the time of the most recent loan application (for those firms that never } \\
\text { applied as in the CREDACCESS models, we substitute LNAGE for LNAGE2). }\end{array}$ & & & & $\mathrm{X}$ & $\mathrm{X}$ & $\mathrm{X}$ & $\mathrm{X}$ \\
\hline SOURCES & Number of institutions that the firm uses for all financial services. & $\mathrm{X}$ & $\mathrm{X}$ & $\mathrm{X}$ & $\mathrm{X}$ & $\mathrm{X}$ & & \\
\hline LEND_SRC & $\begin{array}{l}\text { Number of distinct lending sources used by the firm for lines of credit, equipment loans, motor } \\
\text { vehicle loans, mortgage loans, capital leases, or other loans. }\end{array}$ & & & & & & $\mathrm{X}$ & $\mathrm{X}$ \\
\hline CHECKING & Indicates whether the firm had any checking accounts. & $\mathrm{X}$ & $\mathrm{X}$ & $\mathrm{X}$ & $\mathrm{X}$ & $\mathrm{X}$ & $\mathrm{X}$ & $\mathrm{X}$ \\
\hline
\end{tabular}




\begin{tabular}{|c|c|c|c|c|c|c|c|c|}
\hline \multirow{2}{*}{\multicolumn{2}{|c|}{$\begin{array}{l}\text { Variables } \\
\text { Firm Characteristics (continued) }\end{array}$}} & \multicolumn{7}{|c|}{ Analysis } \\
\hline & & \multirow{2}{*}{$\begin{array}{r}(1) \\
X\end{array}$} & \multirow{2}{*}{$\begin{array}{l}(2) \\
X\end{array}$} & \multirow{2}{*}{$\begin{array}{r}\text { (3) } \\
X\end{array}$} & \multirow{2}{*}{$\begin{array}{l}\text { (4) } \\
\mathrm{X}\end{array}$} & \multirow{2}{*}{$\begin{array}{l}(5) \\
X\end{array}$} & \multirow{2}{*}{$\begin{array}{l}(6) \\
X\end{array}$} & \multirow{2}{*}{$\begin{array}{l}(7) \\
X\end{array}$} \\
\hline SAVING & $\begin{array}{l}\text { Indicates whether the firm had any savings accounts (includes savings accounts, money market } \\
\text { accounts, share accounts, CDs, or other time deposits; excludes retirement accounts, pension funds, } \\
\text { and trusts). }\end{array}$ & & & & & & & \\
\hline TCUSE & Indicates whether the firm uses trade credit. & $\mathrm{X}$ & $\mathrm{X}$ & $\mathrm{X}$ & $\mathrm{X}$ & $\mathrm{X}$ & $\mathrm{X}$ & $\mathrm{X}$ \\
\hline DENTC & Indicates whether the firm was ever denied trade credit. & $\mathrm{X}$ & $\mathrm{X}$ & $\mathrm{X}$ & $\mathrm{X}$ & $\mathrm{X}$ & $\mathrm{X}$ & $\mathrm{X}$ \\
\hline LOAN4 & Indicates whether the firm has loans other than the most recent loan. & & & & $\mathrm{X}$ & $\mathrm{X}$ & $\mathrm{X}$ & $\mathrm{X}$ \\
\hline LOAN2 & Indicates whether the firm has any loans. & & & $\mathrm{X}$ & & & & \\
\hline PRIM_FIN & Indicates whether the firm's primary institution is a financial institution. & $\mathrm{X}$ & $\mathrm{X}$ & $\mathrm{X}$ & $\mathrm{X}$ & $\mathrm{X}$ & & \\
\hline REL_PRIM & $\begin{array}{l}\text { Number of years the firm has been conducting business with its primary institution (set to zero if } \\
\text { the firm has no primary institution). }\end{array}$ & $\mathrm{X}$ & $\mathrm{X}$ & $\mathrm{X}$ & & & & \\
\hline RELPRIM2 & $\begin{array}{l}\text { Number of years firm has been conducting business with its primary institution at the time of the } \\
\text { most recent loan (set to zero if the firm has no primary institution). }\end{array}$ & & & & $\mathrm{X}$ & $\mathrm{X}$ & & \\
\hline PROP & Indicates whether the firm was a proprietorship. & & & & & & & \\
\hline PARTNER & Indicates whether the firm was a partnership. & $\mathrm{X}$ & $\mathrm{X}$ & $\mathrm{X}$ & $\mathrm{X}$ & $\mathrm{X}$ & $\mathrm{X}$ & $\mathrm{X}$ \\
\hline SCORP & Indicates whether the firm was a s-corporation. & $\mathrm{X}$ & $\mathrm{X}$ & $\mathrm{X}$ & $\mathrm{X}$ & $\mathrm{X}$ & $\mathrm{X}$ & $\mathrm{X}$ \\
\hline CCORP & Indicates whether the firm was a c-corporation. & $\mathrm{X}$ & $X$ & $\mathrm{X}$ & $\mathrm{X}$ & $X$ & $\mathrm{X}$ & $\mathrm{X}$ \\
\hline FRANCHIS & Indicates whether the firm was a franchise. & $\mathrm{X}$ & $\mathrm{X}$ & $\mathrm{X}$ & $X$ & $X$ & $X$ & $\mathrm{X}$ \\
\hline D6_SAME & $\begin{array}{l}\text { Indicates whether the firm's primary sales or delivery of products are in the same area as the firm's } \\
\text { main office. }\end{array}$ & & & & & & & \\
\hline D6_REG & $\begin{array}{l}\text { Indicates whether the firm's primary sales or delivery of products are in the same geographic area } \\
\text { as the firm's main office. }\end{array}$ & $\mathrm{X}$ & $\mathrm{X}$ & $\mathrm{X}$ & $X$ & $\mathrm{X}$ & $\mathrm{X}$ & $\mathrm{X}$ \\
\hline D6_NATN & Indicates whether the firm's primary sales or delivery of products are throughout the United States. & $\mathrm{X}$ & $\mathrm{X}$ & $\mathrm{X}$ & $\mathrm{X}$ & $\mathrm{X}$ & $\mathrm{X}$ & $\mathrm{X}$ \\
\hline D6_OUTSD & Indicates whether the firm's primary sales or delivery of products are outside the United States. & $\mathrm{X}$ & $\mathrm{X}$ & $\mathrm{X}$ & $\mathrm{X}$ & $\mathrm{X}$ & $\mathrm{X}$ & $\mathrm{X}$ \\
\hline FEARDEN2 & $\begin{array}{l}\text { Indicates whether the firm needed credit any time over the past three years but didn't apply for fear } \\
\text { of being turned down. Defined over all firms. }\end{array}$ & $\mathrm{X}$ & $\mathrm{X}$ & & & & & \\
\hline EDENALL & $\begin{array}{l}\text { Indicates whether the firm was denied credit anytime over the past three years. Defined over all } \\
\text { firms. }\end{array}$ & $\mathrm{X}$ & & $\mathrm{X}$ & & & & $\mathrm{X}$ \\
\hline HHI & $\begin{array}{l}\text { Herfindahl-Hirschman index of market concentration derived from June } 1993 \text { FDIC summary of } \\
\text { deposit data. }\end{array}$ & $\mathrm{X}$ & $\mathrm{X}$ & $\mathrm{X}$ & $\mathrm{X}$ & $\mathrm{X}$ & $X$ & $\mathrm{X}$ \\
\hline \multicolumn{9}{|c|}{ Owner Characteristics } \\
\hline AFAM & Indicates whether an African American owns more than $50 \%$ of the firm. & $\mathrm{X}$ & $\mathrm{X}$ & $\mathrm{X}$ & $\mathrm{X}$ & $\mathrm{X}$ & $\mathrm{X}$ & $\mathrm{X}$ \\
\hline ASIAN & Indicates whether an Asian-American owns more than $50 \%$ of the firm. & $\mathrm{X}$ & $\mathrm{X}$ & $\mathrm{X}$ & $\mathrm{X}$ & $\mathrm{X}$ & $\mathrm{X}$ & $\mathrm{X}$ \\
\hline HISPAN & Indicates whether a Hispanic-American owns more than $50 \%$ of the firm. & $\mathrm{X}$ & $\mathrm{X}$ & $\mathrm{X}$ & $\mathrm{X}$ & $\mathrm{X}$ & $\mathrm{X}$ & $\mathrm{X}$ \\
\hline FEMALE & Indicates whether a woman owns more than $50 \%$ of the firm. & $\mathrm{X}$ & $\mathrm{X}$ & $\mathrm{X}$ & $\mathrm{X}$ & $\mathrm{X}$ & $\mathrm{X}$ & $\mathrm{X}$ \\
\hline OWNSHR & Percentage of the firm that is owned by the principal owner. & $\mathrm{X}$ & $X$ & $\mathrm{X}$ & $\mathrm{X}$ & $\mathrm{X}$ & $\mathrm{X}$ & $\mathrm{X}$ \\
\hline EXPER & Number of years of experience that the principal owner has had owning or managing a business. & $\mathrm{X}$ & $\mathrm{X}$ & $\mathrm{X}$ & $\mathrm{X}$ & $\mathrm{X}$ & $\mathrm{X}$ & $\mathrm{X}$ \\
\hline NOT_HS & Indicates whether the firm's principal owner is a non-graduate of high school. & $\mathrm{X}$ & $\mathrm{X}$ & $\mathrm{X}$ & $\mathrm{X}$ & $\mathrm{X}$ & $X$ & $\mathrm{X}$ \\
\hline COLLEGE & Indicates whether the firm's principal owner has had some level of college education. & $\mathrm{X}$ & $\mathrm{X}$ & $\mathrm{X}$ & $\mathrm{X}$ & $\mathrm{X}$ & $\mathrm{X}$ & $\mathrm{X}$ \\
\hline MANAGE & Indicates whether the firm is managed on a daily basis by the owner or a partner. & $X$ & $X$ & $X$ & $X$ & $X$ & $X$ & $X$ \\
\hline
\end{tabular}




\begin{tabular}{|c|c|c|c|c|c|c|c|c|}
\hline \multirow{2}{*}{\multicolumn{2}{|c|}{$\begin{array}{l}\text { Variables } \\
\text { Owner Characteristics (continued) }\end{array}$}} & \multicolumn{7}{|c|}{ Analysis } \\
\hline & & \multirow{3}{*}{$\begin{array}{l}(1) \\
X\end{array}$} & \multirow{3}{*}{$\begin{array}{l}(2) \\
X\end{array}$} & \multirow{3}{*}{$\begin{array}{l}(3) \\
X\end{array}$} & \multirow{3}{*}{$\begin{array}{l}(4) \\
X\end{array}$} & \multirow{3}{*}{$\begin{array}{l}(5) \\
X\end{array}$} & \multirow{3}{*}{$\begin{array}{l}(6) \\
X\end{array}$} & \multirow{3}{*}{$\begin{array}{l}(7) \\
X\end{array}$} \\
\hline BANKRUPT & Indicates whether the firm's principal owner declared bankruptcy within the last seven years. & & & & & & & \\
\hline PDELINQ0 & $\begin{array}{l}\text { Indicates whether the firm's principal owner was never delinquent on personal obligations within } \\
\text { the last three years. }\end{array}$ & & & & & & & \\
\hline PDELINQ1 & $\begin{array}{l}\text { Indicates whether the firm's principal owner was } 60 \text { or more days delinquent on personal } \\
\text { obligations } 1 \text { time within the last three years }\end{array}$ & $X$ & $X$ & $\mathrm{X}$ & $\mathrm{X}$ & $\mathrm{X}$ & $X$ & $\mathrm{X}$ \\
\hline PDELINQ2 & $\begin{array}{l}\text { Indicates whether the firm's principal owner was } 60 \text { or more days delinquent on personal } \\
\text { obligations } 2 \text { times within the last three years. }\end{array}$ & $X$ & $X$ & $\mathrm{X}$ & $\mathrm{X}$ & $\mathrm{X}$ & $\mathrm{X}$ & $X$ \\
\hline PDELINQ3 & $\begin{array}{l}\text { Indicates whether the firm's principal owner was } 60 \text { or more days delinquent on personal } \\
\text { obligations } 3 \text { or more times within the last three years. }\end{array}$ & $X$ & $X$ & $\mathrm{X}$ & $\mathrm{X}$ & $\mathrm{X}$ & $\mathrm{X}$ & $X$ \\
\hline BDELINQ0 & $\begin{array}{l}\text { Indicates whether the firm's principal owner was never delinquent on business obligations within } \\
\text { the last three years. }\end{array}$ & & & & & & & \\
\hline BDELINQ1 & $\begin{array}{l}\text { Indicates whether the firm's principal owner was } 60 \text { or more days delinquent on business } \\
\text { obligations } 1 \text { time within the last three years. }\end{array}$ & $X$ & $X$ & $\mathrm{X}$ & $\mathrm{X}$ & $X$ & $\mathrm{X}$ & $\mathrm{X}$ \\
\hline BDELINQ2 & $\begin{array}{l}\text { Indicates whether the firm's principal owner was } 60 \text { or more days delinquent on business } \\
\text { obligations } 2 \text { times within the last three years. }\end{array}$ & $X$ & $X$ & $\mathrm{X}$ & $\mathrm{X}$ & $\mathrm{X}$ & $\mathrm{X}$ & $\mathrm{X}$ \\
\hline BDELINQ3 & $\begin{array}{l}\text { Indicates whether the firm's principal owner was } 60 \text { or more days delinquent on business } \\
\text { obligations } 3 \text { or more times within the last three years. }\end{array}$ & $\mathrm{X}$ & $\mathrm{X}$ & $\mathrm{X}$ & $\mathrm{X}$ & $\mathrm{X}$ & $\mathrm{X}$ & $\mathrm{X}$ \\
\hline JUDGMENT & $\begin{array}{l}\text { Indicates whether any judgments have been rendered against the principal owner within the past } \\
\text { three years. }\end{array}$ & $X$ & $X$ & $\mathrm{X}$ & $\mathrm{X}$ & $X$ & $X$ & $X$ \\
\hline CREDSCR & $\begin{array}{l}\text { Credit score percentile ranging from } 0 \text { to } 100 \text { percent, with } 100 \text { percent being the best credit rating. } \\
\text { Created by Dun \& Bradstreet. }\end{array}$ & $\mathrm{X}$ & $X$ & $\mathrm{X}$ & $\mathrm{X}$ & $\mathrm{X}$ & $\mathrm{X}$ & $\mathrm{X}$ \\
\hline \multicolumn{9}{|c|}{ Most Recent Loan Characteristics } \\
\hline MRL_INDX & $\begin{array}{l}\text { Interest rate of the index to which the most recent loan was tied. For fixed rate loans it is the market } \\
\text { prime rate. }\end{array}$ & & & & & & & $\mathrm{X}$ \\
\hline POINTS & Number of points paid to close (extreme observations set to the $99^{\text {th }}$ percentile). & & & & & & & $\mathrm{X}$ \\
\hline FEE_AMT & Fees paid to close divided by amount borrowed (extreme observations set to the $99^{\text {th }}$ percentile). & & & & & & & $\mathrm{X}$ \\
\hline FIXED & Indicates whether the interest rate on the firm's most recent loan is fixed (vs. variable). & & & & & & & $\mathrm{X}$ \\
\hline TERMPREM & Yield on a government bond of similar maturity minus the yield on treasury bills. & & & & & & & $\mathrm{X}$ \\
\hline INVMAT & Inverse of the maturity of the loan (in months). & & & & & & & $\mathrm{X}$ \\
\hline LNAMTBRR & Natural log of the dollar amount borrowed. & & & & & & & $\mathrm{X}$ \\
\hline BONDSPRD & Yield on corporate bonds rated BAA - yield on ten year government bonds (at time of loan). & & & & & & & $\mathrm{X}$ \\
\hline FIN_JBNK & Indicates whether the firm's most recent loan application was to a financial institution. & & & & & & $\mathrm{X}$ & $\mathrm{X}$ \\
\hline GUAR & Indicates whether the firm was required to have a guarantor. & & & & & & & $\mathrm{X}$ \\
\hline BCOL (PCOL) & Indicates whether the firm provided business (or personal) collateral on its most recent loan. & & & & & & & $\mathrm{X}$ \\
\hline USE_MRL & Indicates whether the most recent loan was intended for short-term financing. & & & & & & $\mathrm{X}$ & \\
\hline MRL_EQP & Indicates whether the most recent loan was for equipment. & & & & & & & \\
\hline MRL_LOC & Indicates whether the most recent loan was a line of credit. & & & & & & $\mathrm{X}$ & $\mathrm{X}$ \\
\hline MRL_LEASE & Indicates whether the most recent loan was a lease. & & & & & & $\mathrm{X}$ & $\mathrm{X}$ \\
\hline MRL_MRTG & Indicates whether the most recent loan was a mortgage. & & & & & & $\mathrm{X}$ & $X$ \\
\hline
\end{tabular}




\begin{tabular}{|c|c|c|c|c|c|c|c|c|}
\hline \multirow{2}{*}{\multicolumn{2}{|c|}{$\begin{array}{l}\text { Variables } \\
\text { Most Recent Loan Characteristics (continued) }\end{array}$}} & \multicolumn{7}{|c|}{ Analysis } \\
\hline & & \multirow[t]{7}{*}{ (1) } & \multirow[t]{7}{*}{$(2)$} & \multirow[t]{7}{*}{ (3) } & \multirow[t]{7}{*}{ (4) } & \multirow[t]{7}{*}{ (5) } & \multirow{3}{*}{$\begin{array}{l}(6) \\
X \\
X\end{array}$} & \multirow{2}{*}{$\begin{array}{r}\text { (7) } \\
X\end{array}$} \\
\hline MRL_MV & Indicates whether the most recent loan was a motor vehicle loan. & & & & & & & \\
\hline MRL_OTH & $\begin{array}{l}\text { Indicates whether the most recent loan was for something other than the above, but excluding loans } \\
\text { from owners. }\end{array}$ & & & & & & & $\mathrm{X}$ \\
\hline J5_ASST & The size of the loan request relative to firm assets. & & & & & & $\mathrm{X}$ & \\
\hline MRL_PRIM & Indicates whether the firm's most recent loan application was to its primary institution. & & & & & & $\mathrm{X}$ & $\mathrm{X}$ \\
\hline MRL_9394 & Indicates whether the firm's most recent loan application was requested in 1993 or 1994. & & & & & & $\mathrm{X}$ & $\mathrm{X}$ \\
\hline REL_JBNK & $\begin{array}{l}\text { Number of years that the firm has been conducting business with the institution where the firm } \\
\text { applied for its most recent loan (set to zero if the firm did not have a relationship with the most } \\
\text { recent lending institution). }\end{array}$ & & & & & & $\mathrm{X}$ & $\mathrm{X}$ \\
\hline \multicolumn{9}{|l|}{ Additional Controls } \\
\hline IND_1 - IND_9 & $\begin{array}{l}\text { Industry controls, based on groupings of two digit SIC codes. IND_1 (SIC 10-19), IND_2 (SIC 20- } \\
\text { 29), IND_3 (SIC 30-39), IND_4 (SIC 40-49), IND_5 (SIC 50-51), IND_6 (SIC 52-59), IND_7 } \\
\text { (SIC 60-69), IND_8 (SIC 70-79), and IND_9 (SIC 80-89). IND_2 is excluded from the analysis. }\end{array}$ & $\mathrm{X}$ & $\mathrm{X}$ & $\mathrm{X}$ & $\mathrm{X}$ & $\mathrm{X}$ & $\mathrm{X}$ & $X$ \\
\hline MSA & Indicates whether the firm's headquarters are located in an MSA (MSA=1) or rural area $(\mathrm{MSA}=0)$ & $\mathrm{X}$ & $\mathrm{X}$ & $\mathrm{X}$ & $\mathrm{X}$ & $\mathrm{X}$ & $\mathrm{X}$ & $\mathrm{X}$ \\
\hline REGION1 - REGION9 & $\begin{array}{l}\text { Census region controls. REGION1 (East North Central - excluded from analysis), REGION2 (East } \\
\text { South Central), REGION3 (Middle Atlantic), REGION4 (Mountain), REGION5 (New England), } \\
\text { REGION6 (Pacific), REGION7 (South Atlantic), REGION8 (West North Central), and REGION9 } \\
\text { (West South Central) }\end{array}$ & $X$ & $X$ & $X$ & $X$ & $X$ & $X$ & $X$ \\
\hline
\end{tabular}


Table 4

Apply: Firm applied for a loan or line of credit within the past three years. Model 1 Model $2 \quad$ Model $3 \quad$ Model $4 \quad$ Model 5

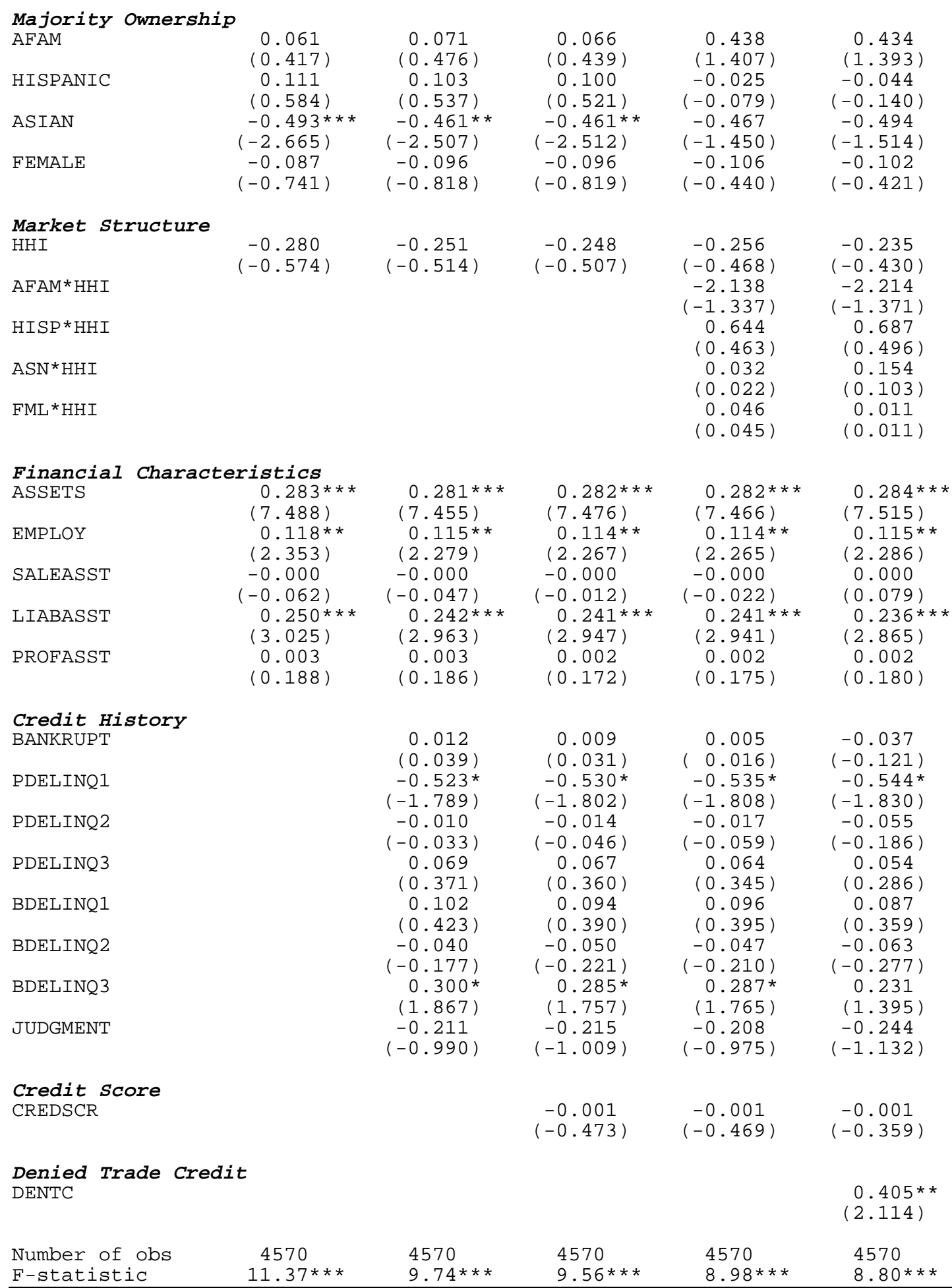

Other variables included in the analysis are: PRIM_FIN, REL_PRIM, CCORP, SCORP, PARTNER, LNAGE, FRANCHIS, D6_NATN, D6_OUTSD, D6_REG, CHECKING, SAVING, NOT_HS, COLLEGE, EXPER, MANAGE, OWNSHR, TCUSE, IND_1, IND_3 - IND_9, MSA, REGION2 - REGION9, SOURCES 


\section{Table 5}

Credit Needs and Application Avoidance by Demographic Group

\begin{tabular}{|c|c|c|c|c|c|c|c|c|c|}
\hline & \multirow[t]{2}{*}{ All } & \multicolumn{2}{|c|}{ White } & \multicolumn{2}{|c|}{ Black } & \multicolumn{2}{|c|}{ Hispanic } & \multicolumn{2}{|c|}{ Asian } \\
\hline & & Males & Females & Males & Females & Males & Females & Males & Females \\
\hline $\begin{array}{l}\text { Percent of Firms that Desired } \\
\text { Credit }\end{array}$ & 48.8 & 48.8 & 44.5 & $69.9 *$ & $78.9 *$ & $60.2 *$ & 55.7 & 41.9 & $33.3 *$ \\
\hline $\begin{array}{l}\text { Percent that Desired Credit } \\
\text { that Feared Denial }\end{array}$ & 49.9 & 45.7 & 50.4 & $84.1^{*}$ & $86.3 *$ & $63.6^{*}$ & $86.5^{*}$ & $61.1 *$ & $80.4^{*}$ \\
\hline $\begin{array}{l}\text { Reasons for Fear of Denial } \\
\text { Poor credit histories or } \\
\text { finances }\end{array}$ & 58.8 & 58.3 & $69.6 *$ & 50.5 & 55.7 & 53.7 & 35.0 & 56.4 & 51.7 \\
\hline Prejudice & 4.6 & 3.1 & 5.2 & $19.8 *$ & $13.4 *$ & 4.9 & 4.9 & 1.1 & 3.8 \\
\hline Other reasons & 44.1 & 43.3 & 41.4 & 42.3 & 46.0 & 52.1 & 63.4 & 48.9 & 51.4 \\
\hline
\end{tabular}

\section{NOTES:}

1. A firm expressed a need for credit if it applied for a loan within the last three years or if it did not apply for a loan within the last three years because it feared that the application would be turned down.

2. Percentages are weighted to reflect population averages. Columns will not add up to 100 since firms were allowed to give up to three reasons for fearing denial.

3. An "**" signifies that the statistic is significantly different from the white-male-owned firm value at the $95 \%$ level of confidence. Standard errors for these tests are calculated using 1,000 bootstrap sample and weight replicates. 
Table 6

Dependent Variable: FearDen: Firm did not apply, fearing denial

Model 1 Model $2 \quad$ Model $3 \quad$ Model $4 \quad$ Model 5

\begin{tabular}{|c|c|c|c|c|c|}
\hline \multicolumn{6}{|l|}{ Majority Ownership } \\
\hline AFAM & $\begin{array}{l}1.491 * \star \star \\
(6.305)\end{array}$ & $\begin{array}{l}1.247 \star \star \star \\
(5.012)\end{array}$ & $\begin{array}{l}1.160 * \star \star \\
(4.701)\end{array}$ & $\begin{array}{l}0.663 \\
(1.298)\end{array}$ & $\begin{array}{l}0.713 \\
(1.398)\end{array}$ \\
\hline HISPANIC & $\begin{array}{l}0.737 \star \star \star \\
(2.652)\end{array}$ & $\begin{array}{l}0.714 * \star \\
(2.469)\end{array}$ & $\begin{array}{l}0.715 * \star \\
(2.413)\end{array}$ & $\begin{array}{l}1.086 * \\
(1.916)\end{array}$ & $\begin{array}{l}1.048 * \\
(1.870)\end{array}$ \\
\hline ASIAN & $\begin{array}{c}0.401 \\
(1.424)\end{array}$ & $\begin{array}{c}0.464 \\
(1.435)\end{array}$ & $\begin{array}{c}0.477 \\
(1.388)\end{array}$ & $\begin{array}{l}0.595 \\
(0.774)\end{array}$ & $\begin{array}{l}0.532 \\
(0.673)\end{array}$ \\
\hline FEMALE & $\begin{array}{l}0.061 \\
(0.350)\end{array}$ & $\begin{array}{l}0.001 \\
(0.005)\end{array}$ & $\begin{array}{l}-0.022 \\
(-0.114)\end{array}$ & $\begin{array}{l}-0.599 \\
(-1.542)\end{array}$ & $\begin{array}{l}-0.586 \\
(-1.511)\end{array}$ \\
\hline \multicolumn{6}{|l|}{ Market Structure } \\
\hline $\mathrm{HHI}$ & $\begin{array}{c}0.552 \\
(0.714)\end{array}$ & $\begin{array}{c}0.503 \\
(0.589)\end{array}$ & $\begin{array}{c}0.600 \\
(0.692)\end{array}$ & $\begin{array}{l}-0.200 \\
(-0.196)\end{array}$ & $\begin{array}{l}-0.138 \\
(-0.136)\end{array}$ \\
\hline $\mathrm{AFAM} \mathrm{HHI}$ & & & & $\begin{array}{l}2.816 \\
(1.034)\end{array}$ & $\begin{array}{l}2.482 \\
(0.913)\end{array}$ \\
\hline $\mathrm{HISP} * \mathrm{HHI}$ & & & & $\begin{array}{l}-1.886 \\
(-0.715)\end{array}$ & $\begin{array}{l}-1.831 \\
(-0.690)\end{array}$ \\
\hline $\mathrm{ASN} * \mathrm{HHI}$ & & & & $\begin{array}{l}-0.565 \\
(-0.145)\end{array}$ & $\begin{array}{l}-0.236 \\
(-0.059)\end{array}$ \\
\hline FML $* H H I$ & & & & $\begin{array}{r}2.757 \star \\
(1.780)\end{array}$ & $\begin{array}{l}2.567 \star \\
(1.654)\end{array}$ \\
\hline \multicolumn{6}{|c|}{ Financial Characteristics } \\
\hline ASSETS & $\begin{array}{l}-0.338 \star \star \star \\
(-5.282)\end{array}$ & $\begin{array}{l}-0.355 * \star \star \\
(-5.195)\end{array}$ & $\begin{array}{l}-0.349 * \star \star \\
(-5.143)\end{array}$ & $\begin{array}{l}-0.351 * \star \star \\
(-5.133)\end{array}$ & $\begin{array}{l}-0.352 * \star \star \\
(-5.180)\end{array}$ \\
\hline EMP LOY & $\begin{array}{l}-0.041 \\
(-0.494)\end{array}$ & $\begin{array}{l}-0.041 \\
(-0.482)\end{array}$ & $\begin{array}{l}-0.045 \\
(-0.530)\end{array}$ & $\begin{array}{l}-0.040 \\
(-0.466)\end{array}$ & $\begin{array}{l}-0.034 \\
(-0.398)\end{array}$ \\
\hline SALEASST & $\begin{array}{l}-0.014 * \star \\
(-2.385)\end{array}$ & $\begin{array}{l}-0.011 * \star \\
(-1.975)\end{array}$ & $\begin{array}{l}-0.009 \\
(-1.602)\end{array}$ & $\begin{array}{l}-0.010 * \\
(-1.687)\end{array}$ & $\begin{array}{l}-0.009 \\
(-1.507)\end{array}$ \\
\hline LIABASST & $\begin{array}{l}0.052 \\
(0.396)\end{array}$ & $\begin{array}{l}-0.027 \\
(-0.275)\end{array}$ & $\begin{array}{l}-0.032 \\
(-0.351)\end{array}$ & $\begin{array}{l}-0.026 \\
(-0.282)\end{array}$ & $\begin{array}{l}-0.031 \\
(-0.365)\end{array}$ \\
\hline PROFASST & $\begin{array}{l}-0.039 \\
(-0.968)\end{array}$ & $\begin{array}{l}-0.040 \\
(-0.815)\end{array}$ & $\begin{array}{l}-0.043 \\
(-0.876)\end{array}$ & $\begin{array}{l}-0.042 \\
(-0.845)\end{array}$ & $\begin{array}{l}-0.045 \\
(-0.934)\end{array}$ \\
\hline \multicolumn{6}{|l|}{ Credit History } \\
\hline BANKRUP T & & $\begin{array}{l}0.903 \star \star \\
(2.515)\end{array}$ & $\begin{array}{l}0.907 \star \star \star \\
(2.602)\end{array}$ & $\begin{array}{l}0.888 * \star \\
(2.555)\end{array}$ & $\begin{array}{l}0.808 * \star \\
(2.352)\end{array}$ \\
\hline PDELINQ1 & & $\begin{array}{r}0.748 * \\
(1.759)\end{array}$ & $\begin{array}{r}0.687 * \\
(1.714)\end{array}$ & $\begin{array}{c}0.708 * \\
(1.771)\end{array}$ & $\begin{array}{r}0.732 \star \\
(1.813)\end{array}$ \\
\hline PDELINQ2 & & $\begin{array}{l}-0.018 \\
(-0.043)\end{array}$ & $\begin{array}{l}-0.028 \\
(-0.063)\end{array}$ & $\begin{array}{l}-0.043 \\
(-0.100)\end{array}$ & $\begin{array}{l}-0.151 \\
(-0.332)\end{array}$ \\
\hline PDELINQ3 & & $\begin{array}{l}0.918 * \star \star \\
(3.420)\end{array}$ & $\begin{array}{l}0.919 * \star \star \\
(3.446)\end{array}$ & $\begin{array}{l}0.920 * \star \star \\
(3.439)\end{array}$ & $\begin{array}{l}0.942 * \star \star \\
(3.483)\end{array}$ \\
\hline BDELINQ1 & & $\begin{array}{l}0.321 \\
(0.950)\end{array}$ & $\begin{array}{l}0.253 \\
(0.768)\end{array}$ & $\begin{array}{c}0.217 \\
(0.662)\end{array}$ & $\begin{array}{l}0.198 \\
(0.578)\end{array}$ \\
\hline BDELINQ2 & & $\begin{array}{l}1.826^{\star \star \star} \\
(5.215)\end{array}$ & $\begin{array}{l}1.694 * \star \star \\
(4.683)\end{array}$ & $\begin{array}{l}1.693 * \star \star \\
(4.720)\end{array}$ & $\begin{array}{l}1.663 * \star \star \\
(4.653)\end{array}$ \\
\hline BDELINQ3 & & $\begin{array}{l}1.115 * \star \star \\
(5.782)\end{array}$ & $\begin{array}{l}0.915 * \star \star \\
(4.707)\end{array}$ & $\begin{array}{l}0.916 * \star \star \\
(4.688)\end{array}$ & $\begin{array}{l}0.790 * \star \star \\
(3.967)\end{array}$ \\
\hline JUDGMENT & & $\begin{array}{l}0.764^{\star \star} \\
(2.334)\end{array}$ & $\begin{array}{l}0.720 * \star \\
(2.219)\end{array}$ & $\begin{array}{l}0.710 * \star \\
(2.163)\end{array}$ & $\begin{array}{l}0.660 * \\
(1.923)\end{array}$ \\
\hline \multicolumn{6}{|l|}{ Credit Score } \\
\hline CREDSCR & & & $\begin{array}{l}-0.010 * \star \star \\
(-3.789)\end{array}$ & $\begin{array}{l}-0.010 * \star \star \\
(-3.807)\end{array}$ & $\begin{array}{l}-0.009 * \star \star \\
(-3.634)\end{array}$ \\
\hline $\begin{array}{l}\text { Denied Trade Credit } \\
\text { DENTC }\end{array}$ & & & & & $\begin{array}{l}0.909 * \star \star \\
(3.305)\end{array}$ \\
\hline Number of obs & 2609 & 2609 & 2609 & 2609 & 2609 \\
\hline F-statistic & $7.15 * \star \star$ & $6.96 * * *$ & $7.05 * \star \star$ & $6.71 * \star \star$ & $6.57 * \star \star$ \\
\hline
\end{tabular}

Other variables included in the analysis are: PRIM_FIN, REL_PRIM, CCORP, SCORP, PARTNER, LNAGE, FRANCHIS, D6_NATN, D6_OUTSD, D6_REG, CHECKING, SAVING, NOT_HS, COLLEGE, EXPER, MANAGE, OWNSHR, TCUSE, IND_1, IND_3 - IND_9, MSA, REGION2 - REGION9, SOURCES, LOAN2, EDENALL 
Table 7

Dependent Variable: EverDen: Firm denied credit anytime over the past three years. Model 1 Model $2 \quad$ Model $3 \quad$ Model $4 \quad$ Model 5

\begin{tabular}{|c|c|c|c|c|c|}
\hline \multirow{2}{*}{\multicolumn{6}{|c|}{ Majority Ownership }} \\
\hline & & & & & \\
\hline AFÄ & $\begin{array}{l}1.481 * \star \star \\
(6.055)\end{array}$ & $\begin{array}{l}1.151 * \star \star \\
(4.476)\end{array}$ & $\begin{array}{l}1.084 * \star \star \\
(4.131)\end{array}$ & $\begin{array}{l}-0.315 \\
(-0.454)\end{array}$ & $\begin{array}{l}-0.249 \\
(-0.364)\end{array}$ \\
\hline HISPANIC & $\begin{array}{c}0.412 \\
(1.190)\end{array}$ & $\begin{array}{c}0.368 \\
(1.055)\end{array}$ & $\begin{array}{c}0.351 \\
(1.012)\end{array}$ & $\begin{array}{l}-0.012 \\
(-0.019)\end{array}$ & $\begin{array}{l}-0.052 \\
(-0.077)\end{array}$ \\
\hline ASIAN & $0.603 *$ & 0.579 & 0.575 & 1.577 & 1.295 \\
\hline & $(1.775)$ & $(1.535)$ & $(1.424)$ & $(1.454)$ & $(1.135)$ \\
\hline FEMALE & $\begin{array}{c}0.024 \\
(0.117)\end{array}$ & $\begin{array}{l}-0.055 \\
(-0.253)\end{array}$ & $\begin{array}{l}-0.064 \\
(-0.293)\end{array}$ & $\begin{array}{l}-1.389 * \star \star \\
(-2.865)\end{array}$ & $\begin{array}{l}-1.406 \star \star \star \\
(-2.847)\end{array}$ \\
\hline \multicolumn{6}{|l|}{ Market Structure } \\
\hline $\mathrm{HHI}$ & $\begin{array}{l}-0.362 \\
(-0.309)\end{array}$ & $\begin{array}{l}-0.636 \\
(-0.518)\end{array}$ & $\begin{array}{l}-0.537 \\
(-0.434)\end{array}$ & $\begin{array}{l}-2.144^{\star} \\
(-1.722)\end{array}$ & $\begin{array}{l}-2.310 \star \\
(-1.929)\end{array}$ \\
\hline $\mathrm{AFAM} \star \mathrm{HHI}$ & & & & $\begin{array}{l}8.346 * \star \\
(1.973)\end{array}$ & $\begin{array}{l}7.909 * \\
(1.957)\end{array}$ \\
\hline $\mathrm{HISP} * \mathrm{HHI}$ & & & & $\begin{array}{l}1.975 \\
(0.676)\end{array}$ & $\begin{array}{l}2.292 \\
(0.788)\end{array}$ \\
\hline $\mathrm{ASN} * \mathrm{HHI}$ & & & & -5.549 & -3.851 \\
\hline $\mathrm{FML} \star \mathrm{HHI}$ & & & & $\begin{array}{c}(-0.994) \\
6.481 * \star \star \\
(3.065)\end{array}$ & $\begin{array}{c}(-0.607 * \star \\
(2.965)\end{array}$ \\
\hline \multicolumn{6}{|c|}{ Financial Characteristics } \\
\hline ASSETS & $\begin{array}{l}-0.212 * \star \star \\
(-3.106)\end{array}$ & $\begin{array}{l}-0.196 * \star \star \\
(-2.747)\end{array}$ & $\begin{array}{l}-0.189 * * \star \\
(-2.665)\end{array}$ & $\begin{array}{l}-0.189 * * \star \\
(-2.645)\end{array}$ & $\begin{array}{l}-0.192 \star \star \star \\
(-2.621)\end{array}$ \\
\hline EMP LOY & $\begin{array}{l}-0.014 \\
(-0.161)\end{array}$ & $\begin{array}{l}-0.018 \\
(-0.191)\end{array}$ & $\begin{array}{l}-0.021 \\
(-0.220)\end{array}$ & $\begin{array}{l}-0.019 \\
(-0.198)\end{array}$ & $\begin{array}{l}-0.037 \\
(-0.387)\end{array}$ \\
\hline SALEASST & $\begin{array}{l}0.000 \\
(0.046)\end{array}$ & $\begin{array}{c}0.005 \\
(0.487)\end{array}$ & $\begin{array}{c}0.006 \\
(0.623)\end{array}$ & $\begin{array}{l}0.005 \\
(0.492)\end{array}$ & $\begin{array}{c}0.007 \\
(0.719)\end{array}$ \\
\hline LIABASST & $\begin{array}{l}-0.065 \\
(-1.061)\end{array}$ & $\begin{array}{l}-0.115 \star \\
(-1.670)\end{array}$ & $\begin{array}{l}-0.115 \\
(-1.599)\end{array}$ & $\begin{array}{l}-0.094 \\
(-1.293)\end{array}$ & $\begin{array}{l}-0.109 \\
(-1.383)\end{array}$ \\
\hline PROFASST & $\begin{array}{l}-0.008 \\
(-0.251)\end{array}$ & $\begin{array}{l}-0.016 \\
(-0.550)\end{array}$ & $\begin{array}{l}-0.019 \\
(-0.621)\end{array}$ & $\begin{array}{l}-0.018 \\
(-0.610)\end{array}$ & $\begin{array}{l}-0.019 \\
(-0.624)\end{array}$ \\
\hline \multicolumn{6}{|l|}{ Credit History } \\
\hline BANKRUPT & & $\begin{array}{l}1.149 * \star \\
(2.378)\end{array}$ & $\begin{array}{l}1.197 * \star \\
(2.498)\end{array}$ & $\begin{array}{l}1.196 * \star \\
(2.407)\end{array}$ & $\begin{array}{l}1.083 * \star \\
(2.039)\end{array}$ \\
\hline PDELINQ1 & & $\begin{array}{l}0.555 \\
(0.994)\end{array}$ & $\begin{array}{c}0.550 \\
(0.941)\end{array}$ & $\begin{array}{c}0.599 \\
(0.987)\end{array}$ & $\begin{array}{l}0.646 \\
(1.035)\end{array}$ \\
\hline PDELINQ2 & & $\begin{array}{l}0.499 \\
(0.948)\end{array}$ & $\begin{array}{c}0.482 \\
(0.891)\end{array}$ & $\begin{array}{c}0.452 \\
(0.821)\end{array}$ & $\begin{array}{c}0.266 \\
(0.451)\end{array}$ \\
\hline PDELINQ3 & & $\begin{array}{l}0.988 * \star \star \\
(3.506)\end{array}$ & $\begin{array}{l}0.971 * \star \star \\
(3.437)\end{array}$ & $\begin{array}{l}1.047 * \star \star \\
(3.603)\end{array}$ & $\begin{array}{l}1.014 * \star \star \\
(3.594)\end{array}$ \\
\hline BDELINQ1 & & $\begin{array}{l}0.423 \\
(0.999)\end{array}$ & $\begin{array}{l}0.380 \\
(0.909)\end{array}$ & $\begin{array}{c}0.222 \\
(0.537)\end{array}$ & $\begin{array}{c}0.140 \\
(0.317)\end{array}$ \\
\hline BDELINQ2 & & $\begin{array}{l}0.899 * \star \\
(2.429)\end{array}$ & $\begin{array}{l}0.751 * \star \\
(1.967)\end{array}$ & $\begin{array}{l}0.784 * \star \\
(2.037)\end{array}$ & $\begin{array}{l}0.767 * \star \\
(1.976)\end{array}$ \\
\hline BDELINQ3 & & $\begin{array}{l}0.589 \star \star \star \\
(2.762)\end{array}$ & $\begin{array}{l}0.403^{\star} \\
(1.799)\end{array}$ & $\begin{array}{l}0.395^{\star} \\
(1.750)\end{array}$ & $\begin{array}{c}0.191 \\
(0.836)\end{array}$ \\
\hline JUDGMENT & & $\begin{array}{r}0.673^{*} \\
(1.906)\end{array}$ & $\begin{array}{r}0.637 \star \\
(1.817)\end{array}$ & $\begin{array}{c}0.621 * \\
(1.693)\end{array}$ & $\begin{array}{c}0.483 \\
(1.290)\end{array}$ \\
\hline \multicolumn{6}{|l|}{ Credit Score } \\
\hline CREDSCR & & & $\begin{array}{l}-0.009 * * \star \\
(-3.245)\end{array}$ & $\begin{array}{l}-0.009 * * * \\
(-3.261)\end{array}$ & $\begin{array}{l}-0.009 * \star \star \\
(-3.078)\end{array}$ \\
\hline $\begin{array}{l}\text { Denied Trade Credit } \\
\text { DENTC }\end{array}$ & & & & & $\begin{array}{l}1.317 * \star \star \\
(4.867)\end{array}$ \\
\hline $\begin{array}{l}\text { Number of obs } \\
\text { F-statistic }\end{array}$ & $\begin{array}{l}1985 \\
3.68 * \star \star\end{array}$ & $\begin{array}{l}1985 \\
3.83 \star \star \star\end{array}$ & $\begin{array}{l}1985 \\
3.86 * \star \star\end{array}$ & $\begin{array}{l}1985 \\
3.75 \star \star \star\end{array}$ & $\begin{array}{l}1985 \\
3.82 \star \star \star\end{array}$ \\
\hline
\end{tabular}

Other variables included in the analysis are: PRIM_FIN, RELPRIM2, CCORP, SCORP, PARTNER, LNAGE2, FRANCHIS, D6_NATN, D6_OUTSD, D6_REG, CHECKING, SAVING, NOT_HS, COLLEGE, EXPER, MANAGE, OWNSHR, TCUSE, IND_1, IND_3 - IND_9, MSA, REGION2 - REGION9, SOURCES, LOAN4 
Table 7B

EverDen2: Whether firms expressed credit needs anytime over the past three years.

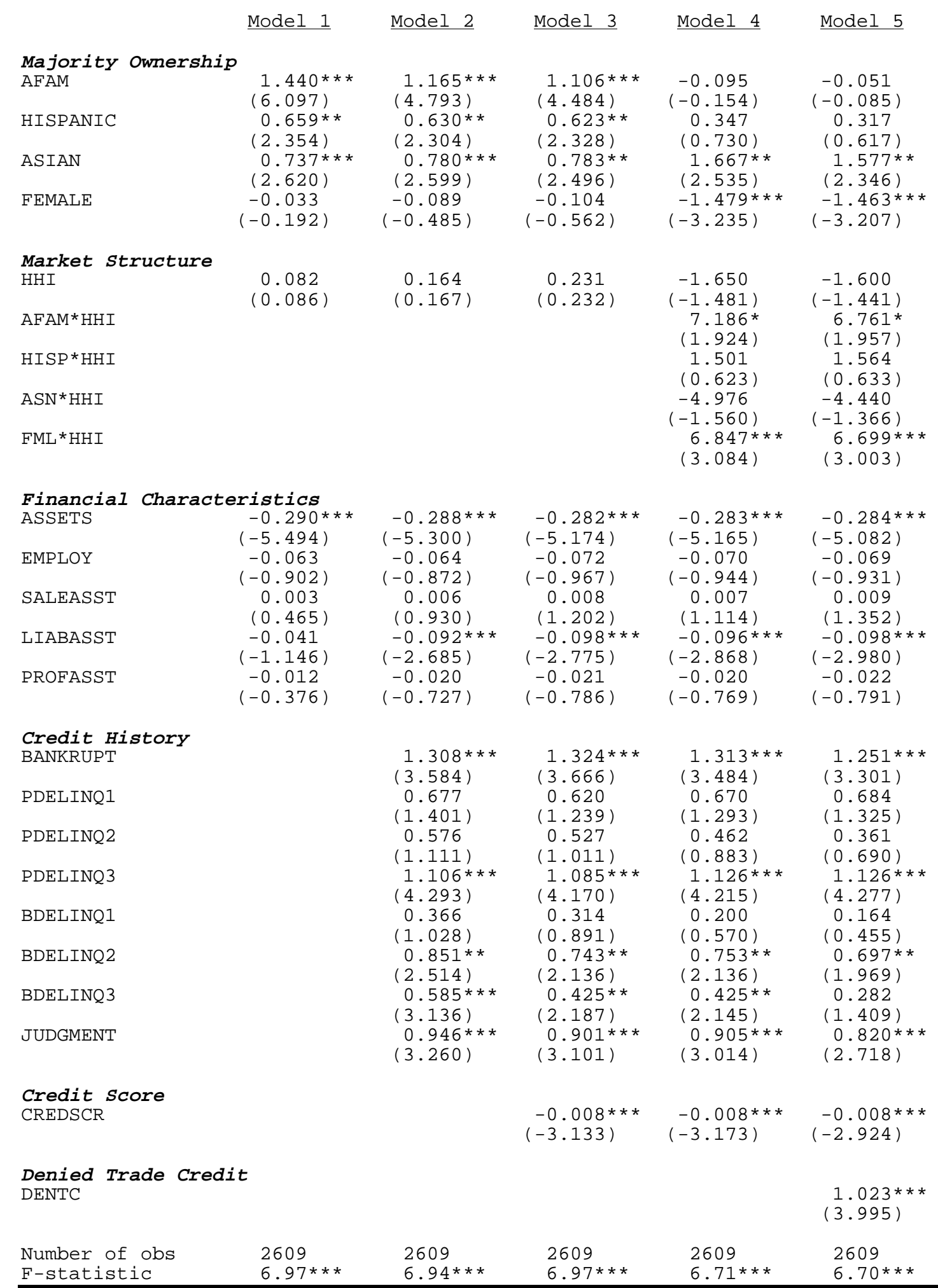

Other variables included in the analysis are: PRIM_FIN, RELPRIM2, CCORP, SCORP, PARTNER, LNAGE2, FRANCHIS, D6_NATN, D6_OUTSD, D6_REG, CHECKING, SAVING, NOT_HS, COLLEGE, EXPER, MANAGE, OWNSHR, TCUSE, IND_1， IND_3 - IND_9, MSA, REGION2 - REGION9, SOURCES, LOAN4 
Table 8

Dependent Variable: DenMRL: Firm Denied for Most Recent Loan Application

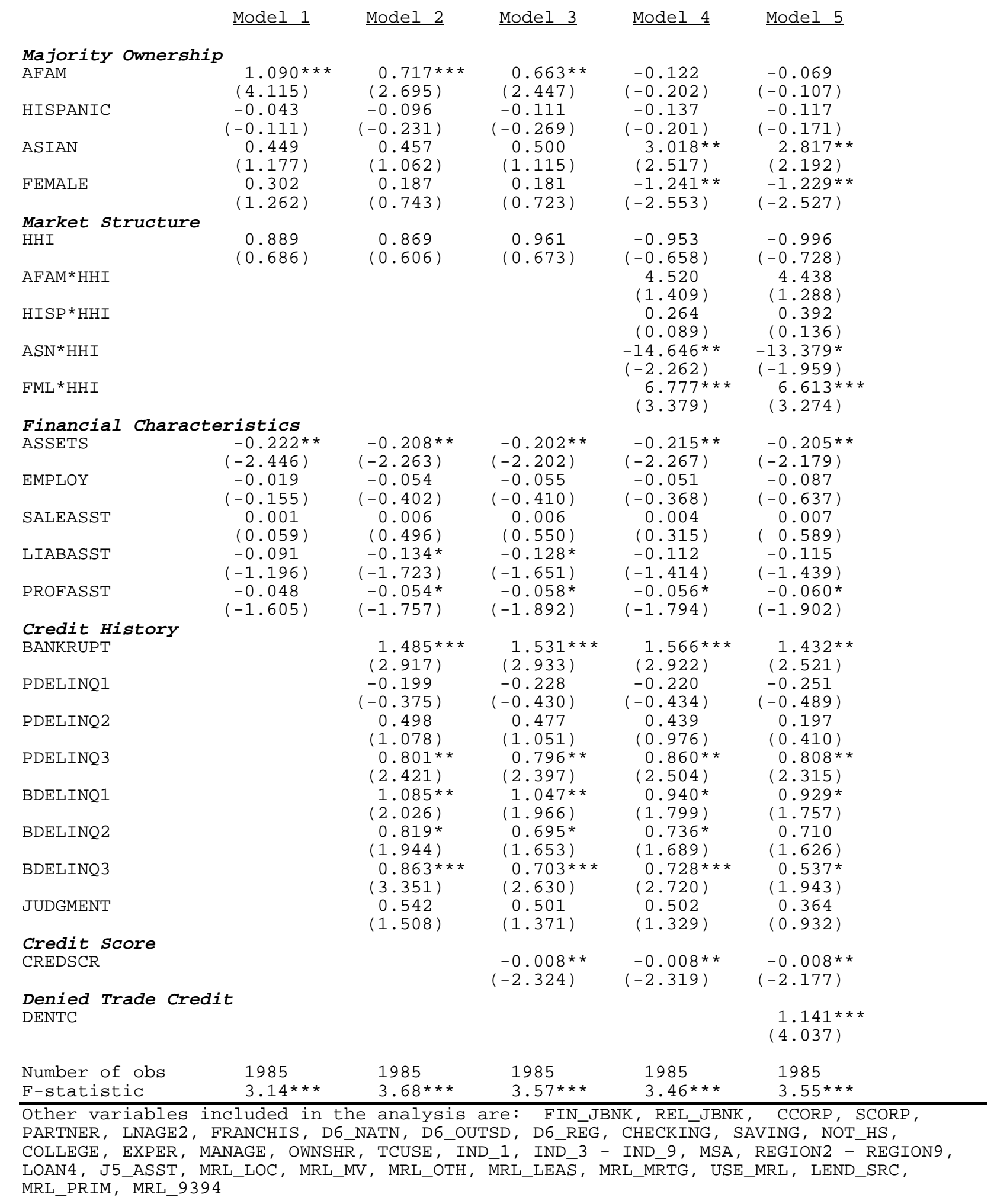


Table 9

Dependent Variable: IntRate: Interest Rate on Most Recent Loan Model 1 Model $2 \quad \underline{\text { Model } 3 \quad \text { Model } 4}$

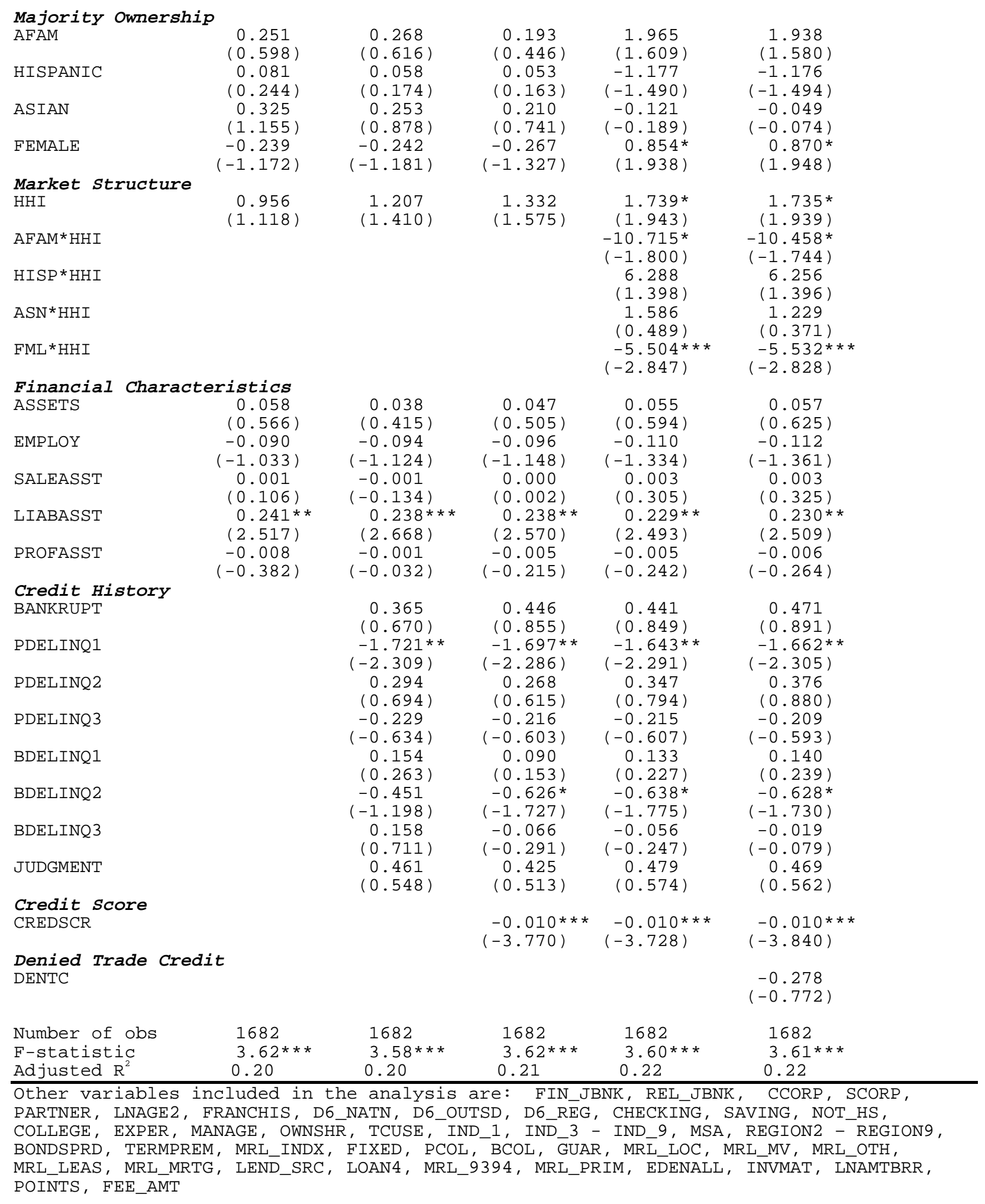




\section{Table 10}

Lines of credit

$\begin{array}{llll}\text { HAVELOC } & \text { APPLYLOC } & \text { DENLOC } & \text { RATELOC } \\ \text { Model 4 } & \text { Model 3 } & \text { Model 4 } & \text { Model 4 }\end{array}$

Majority Ownership AFAM

HISPANIC

ASIAN

FEMALE

Market Structure

HHI

$\mathrm{AFAM} * \mathrm{HHI}$

$\mathrm{HISP}$ *HHI

$\mathrm{ASN} * \mathrm{HHI}$

$\mathrm{FML}$ * $\mathrm{HHI}$

$-0.166$

$(-0.553)$

0.933 *

(2.164)

$-0.214$

$(-0.551)$

0.400

(1.458)

0.812

(1.382)

0.876

(0.597)

$-2.957$

$(-1.402)$

$-2.450$

$(-1.381)$

$-2.476 * \star$

$(-2.123)$

Financial Characteristics

ASSETS

EMP LOY

SALEASST

LIABASST

PROFASST

Credit History

BANKRUP T

PDELINQ1

PDELINQ2

PDELINQ3

BDELINQ1

BDELINQ2

BDELINQ3

JUDGMENT

Credit Score

CREDSCR

Number of obs

F-statistic

Adjusted R2
(7. 784)

$0.194 * \star *$

$(3.572)$

0.007

(1.304)

0.152 **

(2.170)

$-0.011$

$(-0.554)$

$-0.535$

$(-1.471)$

-0.691 *

$(-1.899)$

$-0.119$

$(-0.366)$

$-0.431 * \star$

$(-2.004)$

$-0.062$

$(-0.223)$

$-0.095$

$(-0.360)$

0.320 *

(1.832)

$-0.166$

$(-0.682)$

0.002

(0.921)

4570

$9.09 * \star \star$
0.017

(0.097)

$-0.072$

$(-0.301)$

$-0.526 *$ *

$(-2.313)$

$-0.110$

$(-0.763)$

$$
-0.054
$$

$(-0.094)$

(1)

Model 4

$-2.038 *$

$(-1.660)$

$-0.240$

$(-0.193)$

3. 402

(1.235)

$-1.648 *$

$(-1.753)$

$-2.228$

$(-1.023)$

17.418 **

(2.576)

$-2.861$

$(-0.414)$

$-17.709$

$(-1.108)$

6.760 *

(1.657)

$0.319 * * *$

(7.111)

0.144 **

(2.432)

0.009 *

(1.815)

$0.204 * \star \star$

(2.759)

$-0.001$

$(-0.120)$

$-0.157$

$(-0.413)$

-0.778 *

$(-1.915)$

$-0.456$

$(-1.240)$

0.182

(0.831)

0.050

(0.173)

0.153

(0.572)

0.037

$(0.204)$

-0.478 *

$(-1.699)$

0.000

(0.026)

4570

$8.60 * \star *$
$-0.495 * \star \star$

0.090

(0.379)

0.004

(0.262)

$-0.057$

$(-0.453)$

$-0.032$

$(-0.623)$

1. 421

(1.096)

1.365*

(1.696)

$-0.105$

$(-0.147)$

0.968 *

(1.795)

1.563 *

(1.802)

$1.406 * \star \star$

(2.681)

0.618

(1.415)

$-0.540$

$(-0.927)$

-0.012 **

$(-2.020)$

1126

3. $01 * \star \star$
$(-2.632)$
$-0.656$

$(-1.060)$

-2.124 *

$(-2.156)$

0.605

$(0.932)$

0.330

$(0.637)$

$-0.995$

$(-1.238)$

1. 602

$(0.550)$

12.396 *

(2.211)

$-1.017$

$(-0.253)$

$-1.433$

$(-0.589)$

0.004

(0.035)

$-0.139$

$(-1.689)$

$-0.006$

$(-0.858)$

$0.335 * * *$

(4.039)

$-0.010$

$(-0.540)$

1.205 *

(1.935)

0.130

(0.236)

0.916 *

(2.497)

0.355

(1.050)

$-0.199$

$(-0.391)$

0.052

(0.160)

-0.428 **

$(-2.055)$

$-0.495$

$(-0.983)$

$-0.007 * \star \star$

$(-2.918)$

1001

$8.77 * \star \star$

0.31

Other variables included in the analysis are: PRIM_FIN, REL_PRIM, CCORP, SCORP, PARTNER, LNAGE, FRANCHIS, D6_NATN, D6_OUTSD, D6_REG, CHECKING, SAVING, NOT_HS, COLLEGE, EXPER, MANAGE, OWNSHR, TCUSE, IND_1, IND_3 - IND_9, MSA, REGION2 - REGION9, SOURCES, EDENALL, FEARDEN2

${ }^{2}$ Other variables included in the analysis are: PRIM_FIN, REL_PRIM, CCORP, SCORP, PARTNER, LNAGE, FRANCHIS, D6_NATN, D6_OUTSD, D6_REG, CHECKING, SAVING, NOT_HS, COLLEGE, EXPER, MANAGE, OWNSHR, TCUSE, IND_1, IND_3 - IND_9, MSA, REGION2 - REGION9, SOURCES

${ }^{3}$ Other variables included in the analysis are: FIN_JBNK, REL_JBNK, CCORP, SCORP, PARTNER, LNAGE2, FRANCHIS, D6_NATN, D6_OUTSD, D6_REG, CHECKING, SAVING, NOT_HS, COLLEGE, EXPER, MANAGE, OWNSHR, TCUSE, IND_1, IND_3 - IND_9, MSA, REGION2 - REGION9, LOAN4, J5_ASST, USE_MRL, LEND_SRC, MRL_PRIM, MRL_9394

${ }^{4}$ Other variables included in the analysis are: FIN_JBNK, REL_JBNK, CCORP, SCORP, PARTNER, LNAGE2, FRANCHIS, D6_NATN, D6_OUTSD, D6_REG, CHECKING, SAVING, NOT_HS, COLLEGE, EXPER, MANAGE, OWNSHR, TCUSE, IND_1, IND_3 - IND_9, MSA, REGION2 - REGION9, BONDSPRD, TERMPREM, MRL_INDX, FIXED, PCOL, BCOL, GUAR, LEND_SRC, LOAN4, MRL_9394, MRL_PRIM, EDENALL, INVMAT, LNAMTBRR, POINTS, FEE_AMT 
Table 11

Summary of Results

\begin{tabular}{|c|c|c|c|c|c|c|c|c|c|c|}
\hline & & African American & Hispanic & Asian & Female & $\mathrm{HHI}$ & AFAM*HHI & Hisp*HHI & Asian*HHI & Female*HHI \\
\hline All Loans & Model & & & & & & & & & \\
\hline \multirow[t]{2}{*}{ Loan } & 3 & - & + & $-{ }^{*}$ & - & + & & & & \\
\hline & 4 & - & + & - & - & + & - & - & - & + \\
\hline \multirow[t]{2}{*}{ Apply } & 3 & + & + & $-^{* *}$ & - & - & & & & \\
\hline & 4 & + & - & - & - & + & - & + & + & + \\
\hline \multirow[t]{2}{*}{ FearDen } & 3 & $+* * *$ & $+^{* *}$ & + & - & + & & & & \\
\hline & 4 & $+^{\mathrm{a}}$ & $++^{*}$ & + & - & - & $t^{\mathrm{a}}$ & - & - & $++^{*}$ \\
\hline \multirow[t]{2}{*}{ EverDen } & 3 & $+* * *$ & + & + & - & - & & & & \\
\hline & 4 & - & - & + & $-^{* * * *}$ & $-^{*}$ & $+{ }^{* *}$ & + & - & $+* * *$ \\
\hline \multirow[t]{2}{*}{ EverDen2 } & 3 & $++^{* * * *}$ & $+{ }^{* *}$ & $+* *$ & - & + & & & & \\
\hline & 4 & $-{ }^{\mathrm{a}}$ & $+^{c}$ & $+* * \mathrm{~b}$ & $-^{* * * * a}$ & - & $+{ }^{* a}$ & $+^{\mathrm{c}}$ & $-{ }^{b}$ & $+* * * a$ \\
\hline \multirow[t]{2}{*}{ DenMRL } & 3 & $+^{* *}$ & - & + & + & + & & & & \\
\hline & 4 & $-\mathrm{b}$ & - & $+* * \mathrm{k}$ & $-^{* * a}$ & - & $t^{\mathrm{b}}$ & + & $-^{* * b}$ & $t^{* * * *_{a}}$ \\
\hline \multirow[t]{2}{*}{ IntRate } & 3 & + & + & + & - & + & & & & \\
\hline & 4 & + & - & - & $+{ }^{* a}$ & $+{ }^{*}$ & $-^{*}$ & + & + & $-{ }^{* * * *}$ \\
\hline \multicolumn{11}{|c|}{ Lines of Credit } \\
\hline \multirow[t]{2}{*}{ HAVELOC } & 3 & - & $+*$ & $-{ }^{* * *}$ & - & + & & & & \\
\hline & 4 & - & $+* *$ & - & + & + & + & - & - & $-^{* * *}$ \\
\hline \multirow[t]{2}{*}{ APPLYLOC } & 3 & + & - & -*** & - & - & & & & \\
\hline & 4 & + & + & $-{ }^{b}$ & + & + & - & - & $-{ }^{b}$ & - \\
\hline \multirow[t]{2}{*}{ DENLOC } & 3 & $++^{* *}$ & - & + & - & - & & & & \\
\hline & 4 & $-{ }^{* a}$ & - & + & $-^{*}$ & - & $+* * * a$ & - & - & $+^{*}$ \\
\hline \multirow[t]{2}{*}{ RATELOC } & 3 & - & + & + & + & - & & & & \\
\hline & 4 & - & $-{ }^{*} *_{\mathrm{c}}$ & + & + & - & + & $t^{* * *_{c}}$ & - & - \\
\hline
\end{tabular}

${ }^{\mathrm{a}, \mathrm{b}, \mathrm{c}}$ Demographic dummy and demographic interaction with $\mathrm{HHI}$ is jointly significant at the $1 \%, 5 \%$, and $10 \%$ level. 
Appendices 


\section{Appendix A \\ Loan analysis}

We define Loan equal to one if a firm has at least one loan that was initiated under current ownership, zero otherwise. Loan includes lines of credit, capital leases, equipment loans, mortgages, motor vehicle loans and other loans the firm may have. Loans from owners are

excluded. ${ }^{33}$ Our loan analysis is intended to provide an initial look at the characteristics of firms that hold loans. Differences in the probability of holding a loan across demographic groups, all else equal, may be attributable to a variety of causes, including differences in preferences for financial risk that correlate with demographic characteristics, differences in owner expectations concerning the application process, or differences in lender willingness to extend credit, among others.

\section{Findings}

Table A-1 presents coefficients from a logit model that estimates the probability that a firm will hold a loan. All else equal, we find no statistically significant difference in the propensity of female-, Hispanic-, or African American-owned firms to hold loans relative to firms owned by white-males. Using a ten-percent criterion for statistical significance, Asianowned firms are less likely than others to have loans (Loan Models 1-3). ${ }^{34}$ We find no overall effect of market concentration on the likelihood that small businesses hold loans; "HHI" is statistically insignificant. Loan Model 4 adds interaction terms between lender market concentration and the demographic variables. None of the interaction terms are significant. At this stage of our inquiry, we have little evidence to suggest that demographic attributes of the borrower limit access to credit.

Financial attributes that are positively associated with the likelihood that a firm will hold a loan include the level of assets, the level of employment, and the ratio of liabilities to assets. Among credit history variables, only firms with three or more delinquencies on business obligations in excess of 60 days is statistically associated with loan holdings. The addition of the Dun and Bradstreet credit score has no independent influence on the propensity that a firm will

\footnotetext{
${ }^{33}$ We included loans from owners in our series of robustness checks. Reported results were insensitive to including owner loans in our definition of Loan.

${ }^{34}$ Although the Asian coefficient loses significance in Model 4, the Asian effect remains significant in a joint test of Asian and Asian interacted with the HHI.
} 
hold a loan. Likewise, having been denied trade credit has no independent influence on the propensity to hold a loan. 
Table A-1

Dependent Variable: Loan: Firm has loans.

Model 1 Model 2 Model $3 \quad$ Model $4 \quad$ Model 5

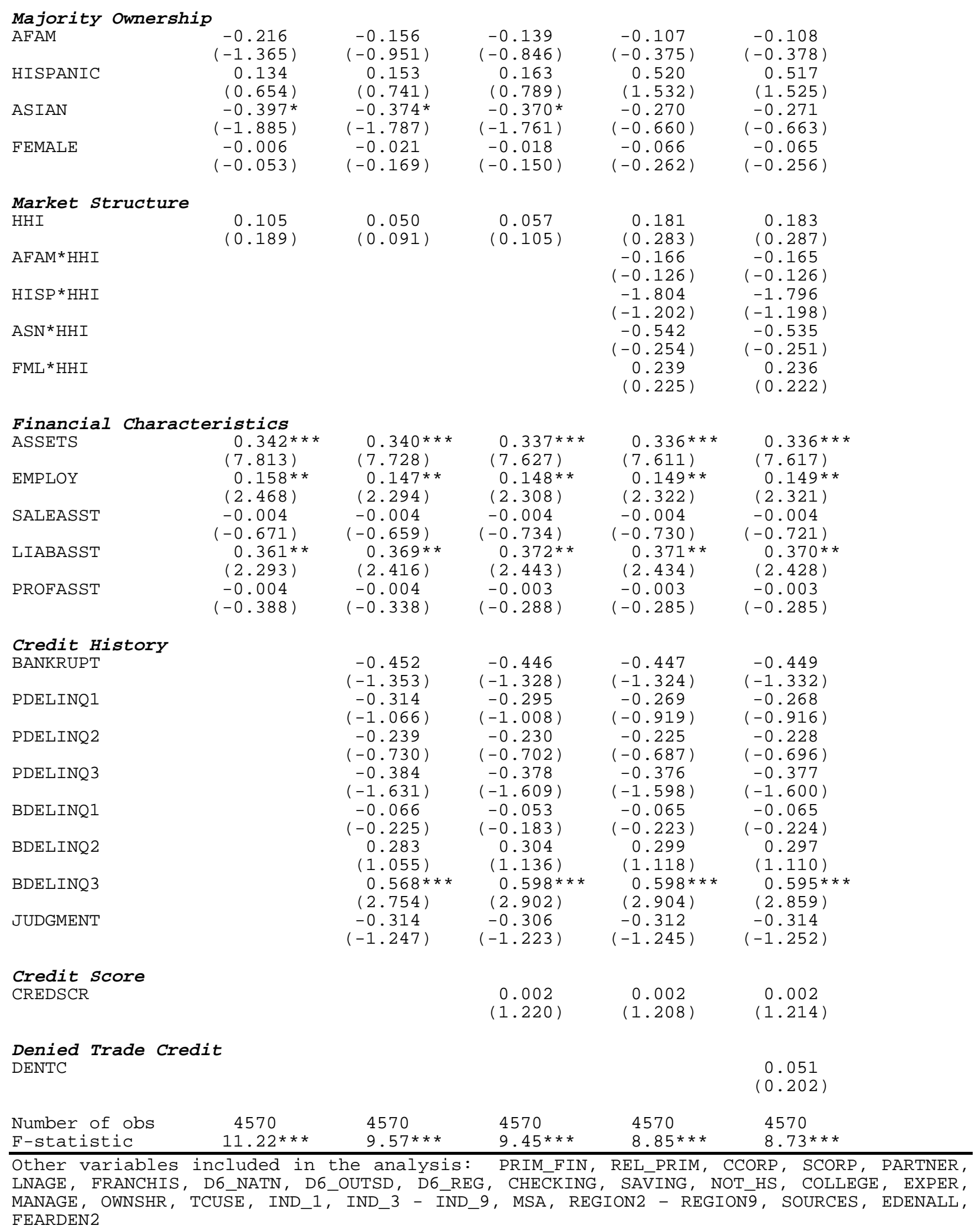




\section{Appendix B \\ Sensitivity Tests}

In addition to the models described in the main text, we test the sensitivity of our results to inclusion of particular segments of the population in our sample. We present estimates of both Model 3 (without herf-demographic interactions) and Model 4 (the full specification) using several different criteria for sample selection. Using the full data set as a benchmark, we first exclude firms with over $\$ 10$ million dollars in assets. One reason for this selection criterion is that while the NSSBF classifies small firms as those with fewer than 500 employees, our discussions with banks indicate that they consider firms with over $\$ 10$ million in sales to be medium sized firms. As a result, these firms may face different benchmarks for credit approval than smaller firms. In addition, larger firms tend to have multiple owners, and these owners needn't be from the same demographic group. Finally, few minority- or female-owned firms in our sample have over $\$ 10$ million dollars in sales. While this selection criterion reduces sample size by almost 10 percent, most of the omitted firms are owned by white-males.

A second subsample considers only those firms that have their headquarters in a MSA. A drawback of this subsample is that it excludes all of the firms that operate in markets with commercial bank monopolies (i.e., those rural counties that have only one commercial bank). Although this exclusion weakens our ability to draw strong conclusions from our test for heightened levels of prejudicial discrimination in concentrated markets, this sample presents an interesting opportunity as well. Since lenders who operate in non-metropolitan areas are likely to be smaller, these institutions may provide managers with more freedom to exercise independent (and possibly discriminatory) rules or preferences in lending. In contrast, banks located in MSA's may be guided by more centralized (and presumably more objective) lending rules.

Our third subsample incorporates both of the criteria described above. A fourth set of results returns to the full sample, but uses a binary specification for HHI, where values of HHI equal to or greater than 0.18 are considered concentrated and set equal to one. ${ }^{35}$ Our fifth set of results is based on the full unweighted sample. Unlike our previous analyses, which make use of weights that adjust for the stratified design of the survey, these results reflect the actual

\footnotetext{
${ }^{35}$ Though not presented in the tables, we also used a logarithmic specification of HHI. Results with the natural $\log$ of HHI were very similar to the untransformed value of HHI.
} 
composition of firms in the sample. Predictions derived from this model are appropriate for the sample, but they cannot be generalized to the full population of small businesses.

\section{Findings}

This section explores the sensitivity of reported results to inclusion of specific segments of the population.

\section{Ever Denied (EverDen)}

Excluding firms with over $\$ 10$ million dollars in sales, though reducing the sample by about $10 \%$, did little to reduce the magnitude or significance of the race and gender coefficients, or the coefficients and their interaction with market concentration. Indeed, the significance of the coefficients of the interaction terms was actually greater in almost every case. In contrast, excluding firms located in non-metropolitan statistical areas did reduce the significance of the African American interaction term below commonly accepted levels of significance, though the signs of the coefficients were unaffected. However, the female interaction term (FML*HHI) remained significant. Eliminating firms with over $\$ 10$ million in sales from the MSA subpopulation did little to alter the demographic coefficients or their significance levels relative to the full MSA sample.

The unweighted regression results are also fairly similar to the weighted results. However, many of the coefficients are larger and have higher levels of significance. For example in Models 1-3 (not shown in table), the coefficients on African American and Asian are always larger than in the weighted estimation, and the Asian coefficient is significant at the one percent level in every case. Regarding the HHI interaction terms (Model 4), while the gender interaction is still positive and significant at the one percent level, the African American interaction, though still large and positive, is now insignificant.

\section{Credit needs (EverDen2)}

Asian owned firms are more likely to be credit constrained than are firms owned by white-males. This result is statistically significant at commonly accepted levels of significance in all five sample specifications. African American- and female-owned firms are more likely to be credit constrained as lender market concentration increases. The coefficients on the African American and female interaction terms (AFAM*HHI and FML*HHI) are large and positive across all sample specifications and are statistically significant in the sample restricted to businesses under $\$ 10$ million in sales. African American interaction terms are not significant in 
the other robustness checks. The female interaction terms are significant in all but the binary HHI specification.

\section{Denied most recent loan (DenMRL)}

We present additional sensitivity tests for the DenMRL analysis in Table B-3. Coefficients on the interaction between African Americans, females, and HHI are large, positive and for females, statistically significant at the one-percent level. Results using a binary HHI in place of the continuous measure still share the same sign on the interaction terms, however the reported level of significance is greatly diminished. Unweighted results (Column 5), support findings reported in Columns 1-3 and Table 8.

Interest rates (IntRate)

The behavior of interest rates across markets and demographic group in our battery of sensitivity tests (Table B-4) follows a pattern similar to that in Column 4 of Table 9, but at varying levels of magnitude and statistical significance. Market concentration has a statistically positive effect on interest rates charged across all specifications except those restricted to businesses located in MSAs. While African American- and female-owned businesses pay more than those owned by white-males at high levels of competition, their rates decline significantly as concentration increases. 
Table B-1 - Model 3

Dependent Variable: EverDen: Firm denied credit anytime over the past three years. Robustness Checks

\begin{tabular}{|c|c|c|c|c|c|}
\hline & $\begin{array}{r}\text { Sales } \\
\leq=\$ 10 \mathrm{M} \\
\end{array}$ & MSA & $\begin{array}{l}\text { MSA \& Sales } \\
<=\$ 10 \mathrm{M}\end{array}$ & $\begin{array}{l}\text { Binary } \\
\text { HHI }\end{array}$ & Unweighted \\
\hline \multicolumn{6}{|c|}{ Majority Ownership } \\
\hline AFAM & $\begin{array}{l}1.085 * \star \star \\
(4.093)\end{array}$ & $\begin{array}{l}0.953 * \star \star \\
(3.611)\end{array}$ & $\begin{array}{l}0.952 * \star \star \\
(3.586)\end{array}$ & $\begin{array}{l}1.084 * \star \star \\
(4.130)\end{array}$ & $\begin{array}{l}1.105 * \star \star \\
(5.178)\end{array}$ \\
\hline HISPANIC & $\begin{array}{l}0.346 \\
(0.978)\end{array}$ & $\begin{array}{c}0.142 \\
(0.361)\end{array}$ & $\begin{array}{c}0.135 \\
(0.335)\end{array}$ & $\begin{array}{c}0.350 \\
(1.010)\end{array}$ & $\begin{array}{c}0.156 \\
(0.638)\end{array}$ \\
\hline ASIAN & $\begin{array}{c}0.653 \\
(1.559)\end{array}$ & $\begin{array}{r}0.657 * \\
(1.648)\end{array}$ & $\begin{array}{l}0.742 * \\
(1.787)\end{array}$ & $\begin{array}{l}0.567 \\
(1.403)\end{array}$ & $\begin{array}{l}0.800 * * \star \\
(2.832)\end{array}$ \\
\hline FEMALE & $\begin{array}{l}-0.050 \\
(-0.225)\end{array}$ & $\begin{array}{l}-0.143 \\
(-0.588)\end{array}$ & $\begin{array}{l}-0.132 \\
(-0.538)\end{array}$ & $\begin{array}{l}-0.059 \\
(-0.269)\end{array}$ & $\begin{array}{c}0.135 \\
(0.775)\end{array}$ \\
\hline \multicolumn{6}{|c|}{ Market structure } \\
\hline HHI & $\begin{array}{l}-0.524 \\
(-0.420)\end{array}$ & $\begin{array}{l}-1.029 \\
(-0.589)\end{array}$ & $\begin{array}{l}-0.967 \\
(-0.543)\end{array}$ & $\begin{array}{l}-0.123 \\
(-0.702)\end{array}$ & $\begin{array}{l}0.008 \\
(0.062)\end{array}$ \\
\hline
\end{tabular}

$A F A M * H H I$

$\mathrm{HISP} * \mathrm{HHI}$

$\mathrm{ASN} * \mathrm{HHI}$

FML ${ }^{*} H H I$

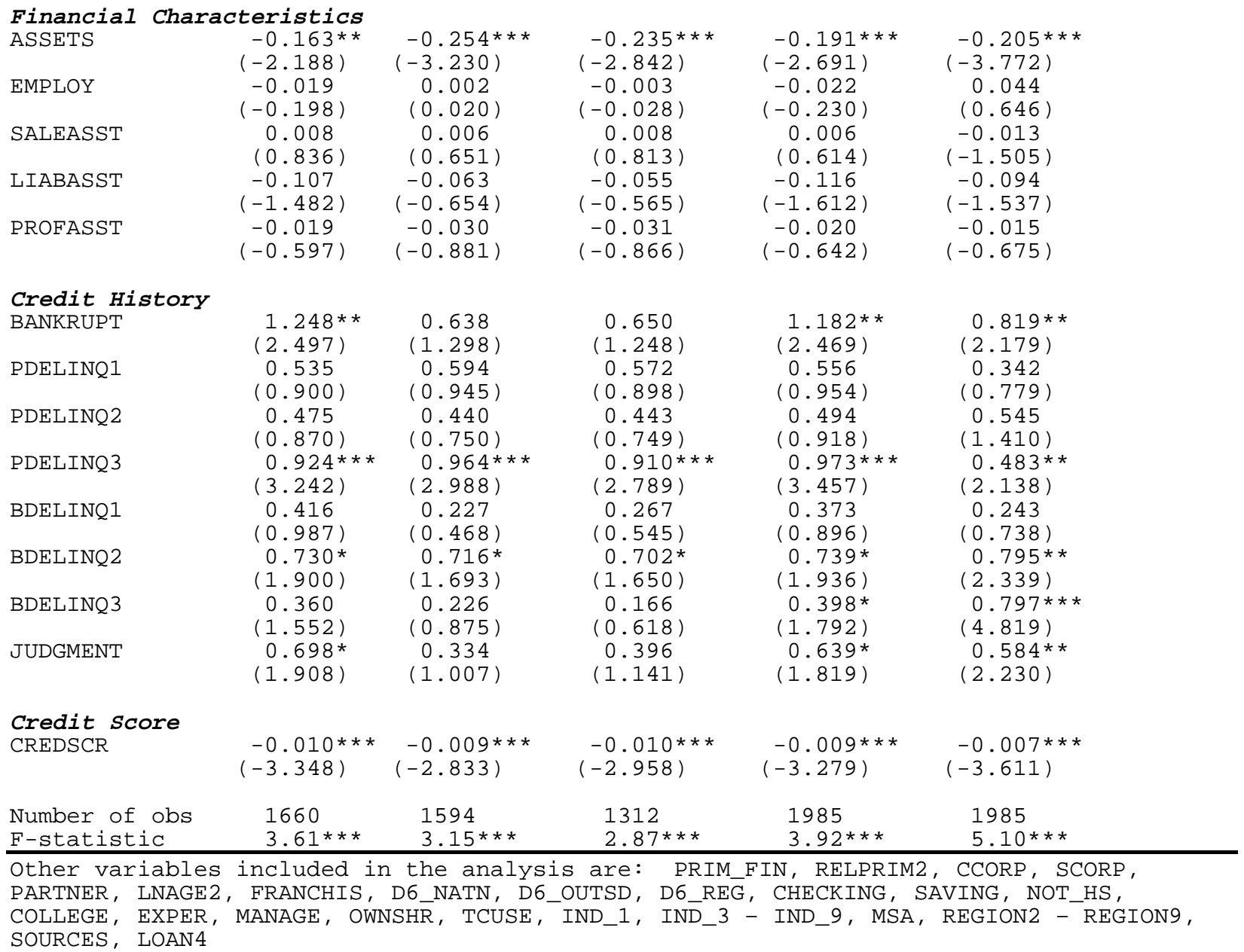


Table B-1 - Model 4

Dependent Variable: EverDen: Firm denied credit anytime over the past three years. Robustness Checks

$\begin{array}{ccccc}\begin{array}{c}\text { Sales } \\ <=\$ 10 \mathrm{M}\end{array} & \text { MSA } & \begin{array}{c}\text { MSA \& Sales } \\ <=\$ 10 \mathrm{M}\end{array} & \begin{array}{c}\text { Binary } \\ \mathrm{HHI}\end{array} & \text { Unweighted }\end{array}$

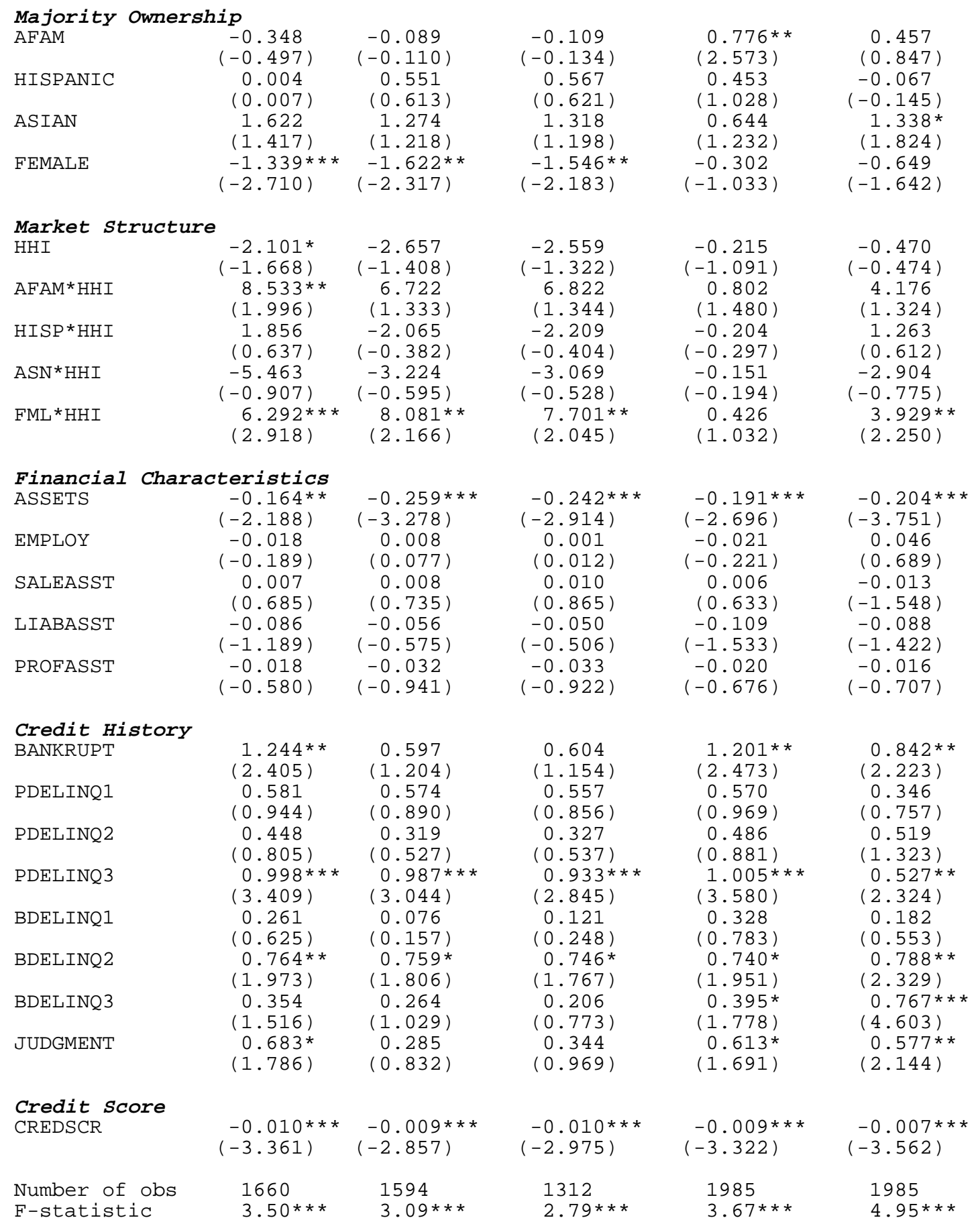

Other variables included in the analysis are: PRIM_FIN, REL_PRIM2, CCORP, SCORP, PARTNER, LNAGE2, FRANCHIS, D6_NATN, D6_OUTSD, D6_REG, CHECKIN̄G, SAVING, NOT_HS, COLLEGE, EXPER, MANAGE, OWNSHR, TCUSE, IND_1, IND_3 - IND_9, MSA, REGION2 - REGION9, SOURCES, LOAN4 
Table B-2 - Model 3

Dependent Variable: EverDen2: Whether Firms Faced Credit Constraints Anytime Over the Past Three years. Robustness Checks

$\begin{array}{ccccc}\begin{array}{c}\text { Sales } \\ \leq=\$ 10 \mathrm{M}\end{array} & \text { MSA } & \begin{array}{c}\text { MSA \& Sales } \\ <=\$ 10 \mathrm{M}\end{array} & \begin{array}{c}\text { Binary } \\ \text { HHI }\end{array} & \text { Unweighted }\end{array}$

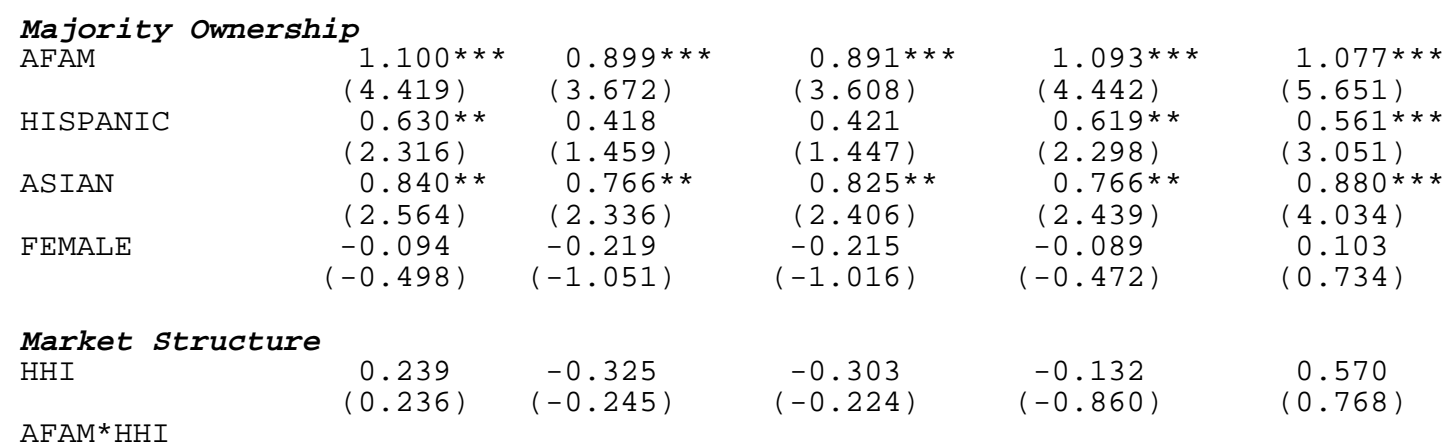

$\mathrm{HISP} * \mathrm{HHI}$

$\mathrm{ASN} * \mathrm{HHI}$

FML *HHI

Financial Characteristics

\begin{tabular}{|c|c|c|c|c|c|}
\hline ASSETS & $-0.262 * \star \star \star$ & $-0.318 * \star \star$ & $-0.302 \star \star \star$ & $-0.281 * \star \star$ & $-0.288 * \star \star *$ \\
\hline & $(-4.639)$ & $(-5.255)$ & $(-4.796)$ & $(-5.172)$ & $(-6.639)$ \\
\hline EMPLOY & $\begin{array}{c}-0.067 \\
(-0.876)\end{array}$ & $\begin{array}{c}-0.094 \\
(-1.163)\end{array}$ & $\begin{array}{c}-0.095 \\
(-1.131)\end{array}$ & $\begin{array}{l}-0.076 \\
(-1.023)\end{array}$ & $\begin{array}{l}-0.005 \\
(-0.085)\end{array}$ \\
\hline SALEASST & $\begin{array}{c}0.009 \\
(1.442)\end{array}$ & $\begin{array}{c}0.008 \\
(1.192)\end{array}$ & $\begin{array}{c}0.010 \\
(1.383)\end{array}$ & $\begin{array}{c}0.008 \\
(1.198)\end{array}$ & $\begin{array}{l}-0.007 \\
(-1.396)\end{array}$ \\
\hline LIABASST & $(-0.097 * \star \star *$ & $\begin{array}{l}(1.064) \\
-0.067 \\
(-1.544)\end{array}$ & $\begin{array}{l}(1.003) \\
-0.067 \\
(-1.454)\end{array}$ & $-0.096 * \star *$ & $(-0.060 * *$ \\
\hline PROFASST & $\begin{array}{l}-0.021 \\
(-0.753)\end{array}$ & $\begin{array}{l}-0.029 \\
(-0.978)\end{array}$ & $\begin{array}{l}-0.029 \\
(-0.945)\end{array}$ & $\begin{array}{l}-0.021 \\
(-0.801)\end{array}$ & $\begin{array}{c}-0.015 \\
(-1.114)\end{array}$ \\
\hline \multicolumn{6}{|l|}{ Credit History } \\
\hline BANKRUP T & $\begin{array}{l}1.342 \star \star \star \\
(3.606)\end{array}$ & $\begin{array}{l}1.046 \star \star \star \\
(3.006)\end{array}$ & $\begin{array}{l}1.042 \star \star \star \\
(2.916)\end{array}$ & $\begin{array}{l}1.304 \star \star \star \\
(3.600)\end{array}$ & $\begin{array}{l}0.971 * \star \star \\
(3.069)\end{array}$ \\
\hline PDELINQ1 & $\begin{array}{c}0.596 \\
(1.173)\end{array}$ & $\begin{array}{c}0.724 \\
(1.334)\end{array}$ & $\begin{array}{c}0.698 \\
(1.269)\end{array}$ & $\begin{array}{c}0.623 \\
(1.259)\end{array}$ & $\begin{array}{c}0.418 \\
(1.232)\end{array}$ \\
\hline PDELINQ2 & $\begin{array}{c}0.515 \\
(0.975)\end{array}$ & $\begin{array}{c}0.478 \\
(0.847)\end{array}$ & $\begin{array}{c}0.471 \\
(0.823)\end{array}$ & $\begin{array}{c}0.538 \\
(1.023)\end{array}$ & $\begin{array}{c}0.523 \\
(1.403)\end{array}$ \\
\hline PDELINQ3 & $\begin{array}{l}1.042 * \star \star \\
(4.012)\end{array}$ & $\begin{array}{l}1.081^{\star \star \star} \\
(3.825)\end{array}$ & $\begin{array}{l}1.027 \star \star \star \\
(3.654)\end{array}$ & $\begin{array}{l}1.082 \star \star \star \\
(4.162)\end{array}$ & $\begin{array}{l}0.617 * \star \star \\
(3.001)\end{array}$ \\
\hline BDELINQ1 & $\begin{array}{l}0.335 \\
(0.932)\end{array}$ & $\begin{array}{c}0.114 \\
(0.289)\end{array}$ & $\begin{array}{c}0.130 \\
(0.323)\end{array}$ & $\begin{array}{l}0.296 \\
(0.847)\end{array}$ & $\begin{array}{c}0.162 \\
(0.598)\end{array}$ \\
\hline BDELINQ2 & $\begin{array}{l}0.731 * \star \\
(2.069)\end{array}$ & $\begin{array}{r}0.606 * \\
(1.659)\end{array}$ & $\begin{array}{c}0.596 \\
(1.606)\end{array}$ & $\begin{array}{l}0.746 * * \\
(2.155)\end{array}$ & $\begin{array}{l}0.784 * \star \\
(2.439)\end{array}$ \\
\hline BDELINQ3 & $\begin{array}{l}0.401 * \star \\
(2.017)\end{array}$ & $\begin{array}{c}0.280 \\
(1.320)\end{array}$ & $\begin{array}{c}0.249 \\
(1.139)\end{array}$ & $\begin{array}{l}0.427 \star \star \\
(2.196)\end{array}$ & $\begin{array}{l}0.685 * \star * \\
(4.555)\end{array}$ \\
\hline JUDGMENT & $\begin{array}{l}0.973 * \star \star \\
(3.183)\end{array}$ & $\begin{array}{l}0.679 * \star \\
(2.334)\end{array}$ & $\begin{array}{l}0.749 * * \\
(2.460)\end{array}$ & $\begin{array}{l}0.916 * \star \star \\
(3.155)\end{array}$ & $\begin{array}{l}0.617 * * * \\
(2.700)\end{array}$ \\
\hline \multicolumn{6}{|l|}{ Credit Score } \\
\hline CREDSCR & $\begin{array}{l}-0.009 * \star \star \\
(-3.252)\end{array}$ & $\begin{array}{l}-0.008 * \star \star \\
(-2.926)\end{array}$ & $\begin{array}{l}-0.009 * * \star \\
(-3.053)\end{array}$ & $\begin{array}{l}-0.008 * \star \star \\
(-3.129)\end{array}$ & $\begin{array}{l}-0.007 * \star \star \\
(-3.548)\end{array}$ \\
\hline Number of obs & 2280 & 2162 & 1877 & 2609 & 2609 \\
\hline F-statistic & $6.46 * \star \star$ & $5.62 * \star \star$ & $5.05 * \star \star$ & $7.03 * \star \star$ & $9.12 * \star \star$ \\
\hline
\end{tabular}

Other variables included in the analysis are: PRIM_FIN, RELPRIM2, CCORP, SCORP, PARTNER, LNAGE2, FRANCHIS, D6_NATN, D6_OUTSD, D6_REG, CHECKING, SAVING, NOT_HS, COLLEGE, EXPER, MANAGE, OWNSHR, TCUSE, IND_1, IND_3 - IND_9, MSA, REGION2 - REGION9, SOURCES, LOAN4 
Table B-2 - Model 4

Dependent Variable: EverDen2: Whether Firms Faced Credit Constraints Anytime Over the Past Three Years. Robustness Checks

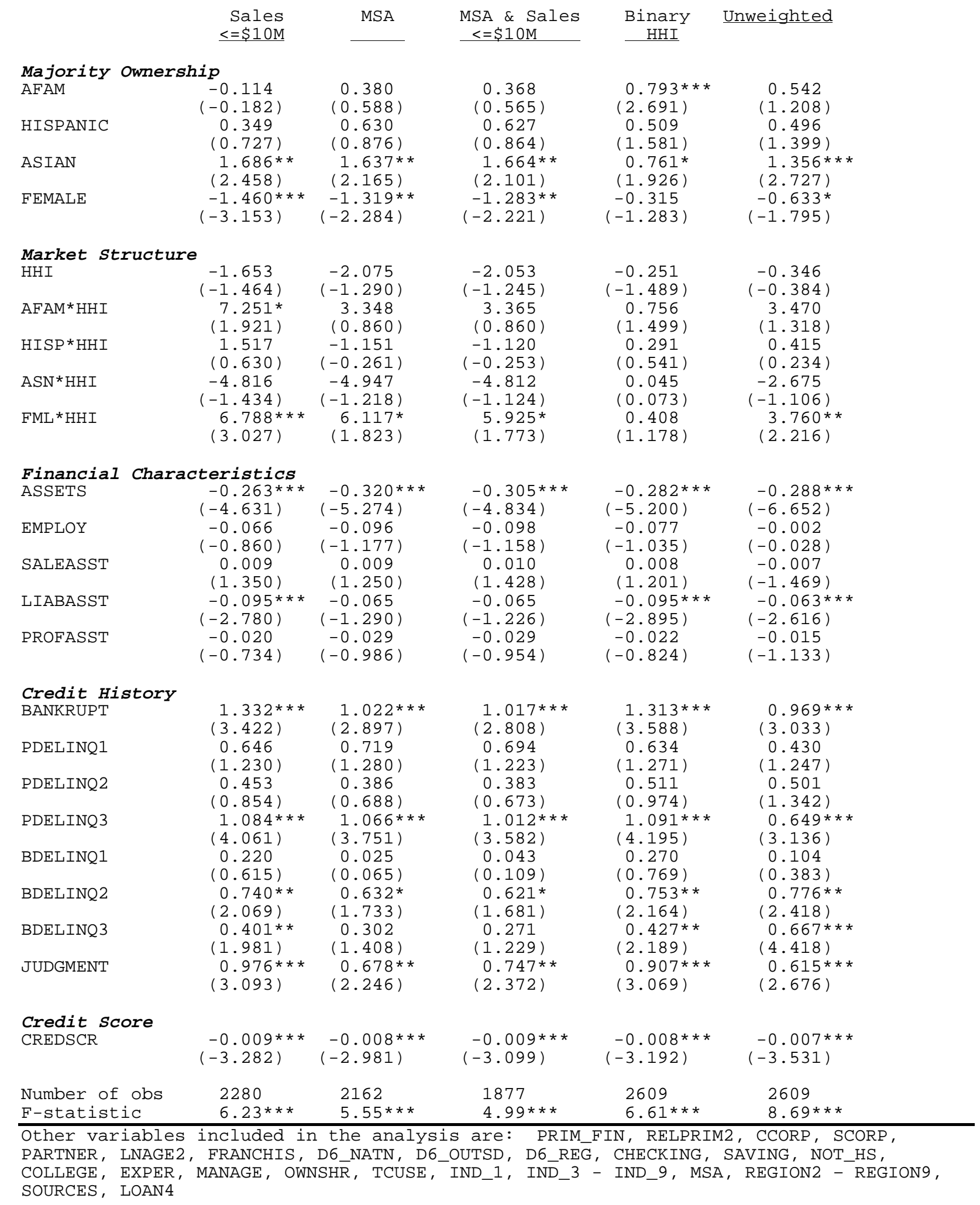


Table B-3 - Model 3

Dependent Variable: DenMRL: Firm Denied for Most Recent Loan Application. Robustness Checks

\begin{tabular}{|c|c|c|c|c|c|}
\hline & $\begin{array}{r}\text { Sales } \\
\leq=\$ 10 \mathrm{M} \\
\end{array}$ & MSA & $\begin{array}{l}\text { MSA \& Sales } \\
<=\$ 10 \mathrm{M} \\
\end{array}$ & $\begin{array}{l}\text { Binary } \\
\text { HHI }\end{array}$ & Unweighted \\
\hline \multicolumn{6}{|c|}{ Majority Ownership } \\
\hline AFAM & $\begin{array}{l}0.655^{\star \star} \\
(2.416)\end{array}$ & $\begin{array}{r}0.557 \star \\
(1.827)\end{array}$ & $\begin{array}{l}0.546^{\star} \\
(1.784)\end{array}$ & $\begin{array}{l}0.645 * \star \\
(2.392)\end{array}$ & $\begin{array}{l}0.804 * \star \star \\
(3.394)\end{array}$ \\
\hline HISPANIC & $\begin{array}{l}-0.113 \\
(-0.273)\end{array}$ & $\begin{array}{l}-0.147 \\
(-0.320)\end{array}$ & $\begin{array}{l}-0.143 \\
(-0.309)\end{array}$ & $\begin{array}{l}-0.093 \\
(-0.229)\end{array}$ & $\begin{array}{l}-0.404 \\
(-1.183)\end{array}$ \\
\hline ASIAN & $\begin{array}{c}0.474 \\
(1.048)\end{array}$ & $\begin{array}{c}0.622 \\
(1.353)\end{array}$ & $\begin{array}{c}0.597 \\
(1.286)\end{array}$ & $\begin{array}{c}0.488 \\
(1.096)\end{array}$ & $\begin{array}{l}0.652 * \\
(1.929)\end{array}$ \\
\hline FEMALE & $\begin{array}{c}0.201 \\
(0.800)\end{array}$ & $\begin{array}{l}0.060 \\
(0.217)\end{array}$ & $\begin{array}{l}0.085 \\
(0.308)\end{array}$ & $\begin{array}{l}0.193 \\
(0.758)\end{array}$ & $\begin{array}{l}-0.050 \\
(-0.236)\end{array}$ \\
\hline \multicolumn{6}{|c|}{ Market Structure } \\
\hline HHI & $\begin{array}{c}0.914 \\
(0.635)\end{array}$ & $\begin{array}{c}0.834 \\
(0.440)\end{array}$ & $\begin{array}{l}0.829 \\
(0.435)\end{array}$ & $\begin{array}{c}0.010 \\
(0.046)\end{array}$ & $\begin{array}{l}1.055 \\
(0.930)\end{array}$ \\
\hline
\end{tabular}

$A F A M * H H I$

HISP * HHI

$\mathrm{ASN}{ }^{*} \mathrm{HHI}$

FML *HH I

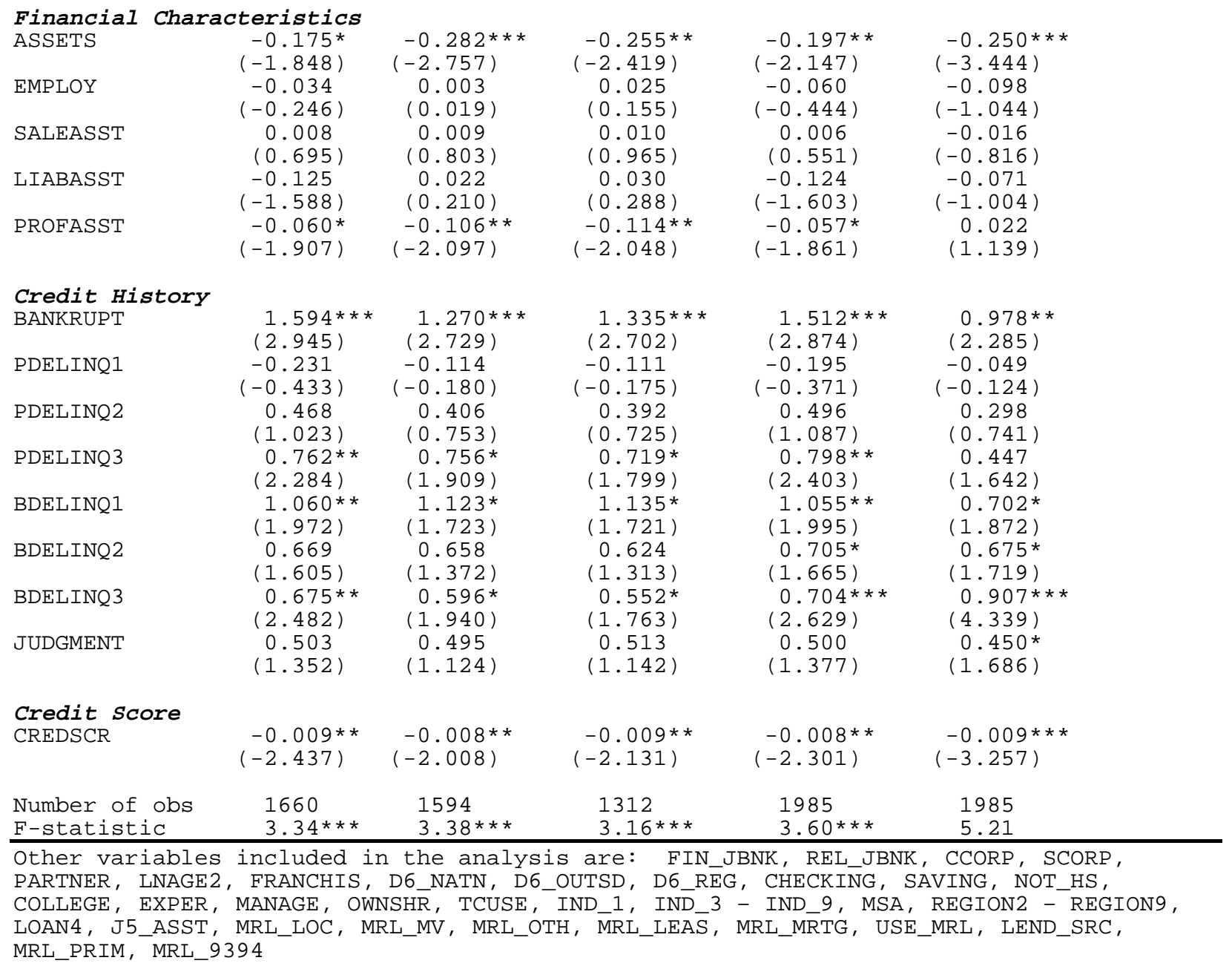


Table B-3 - Model 4

Dependent Variable: DenMRL: Firm Denied for Most Recent Loan Application. Robustness Checks

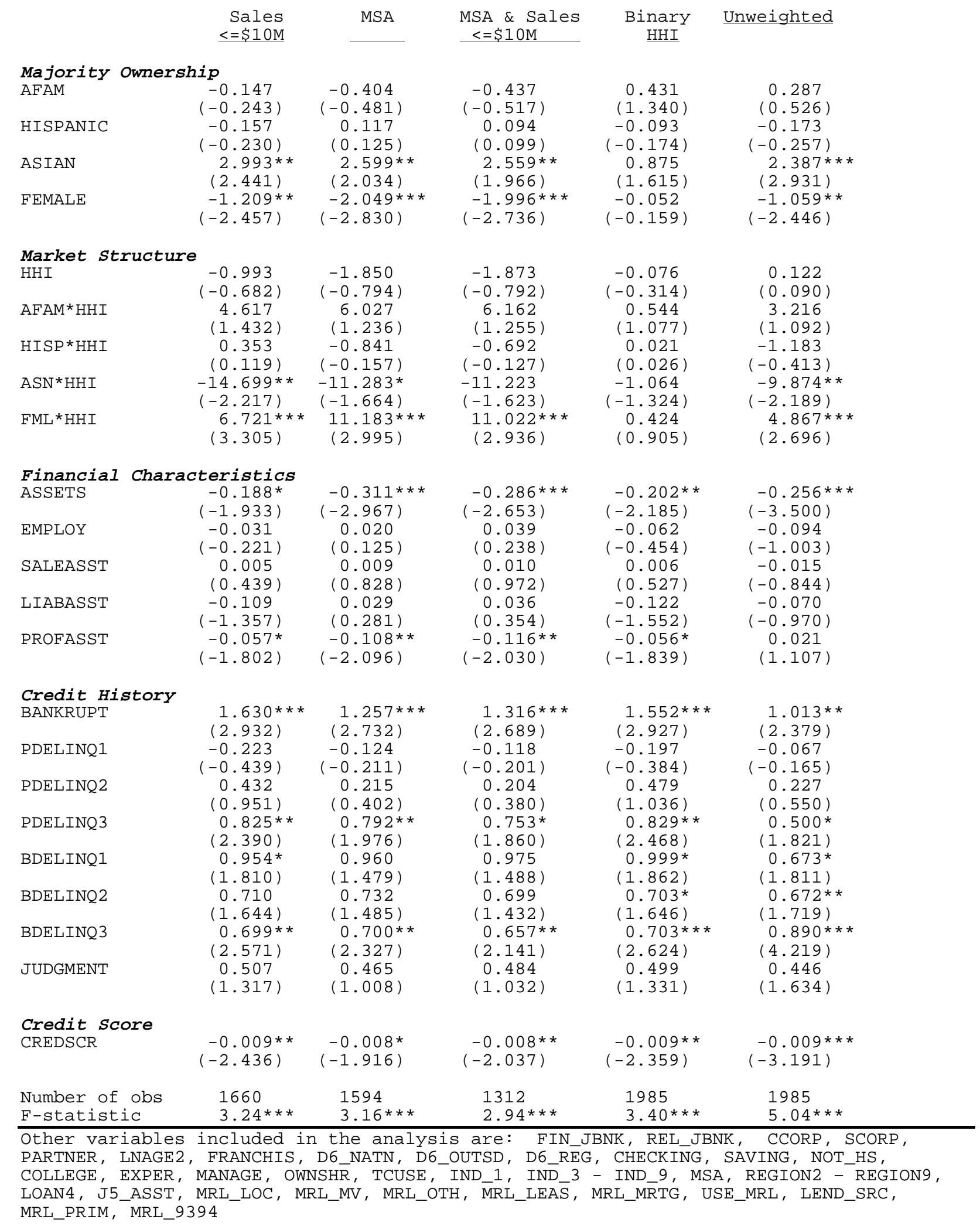


Table B-4 - Model 3

Dependent Variable: IntRate: Interest on Most Recent Loan. Robustness Checks

\begin{tabular}{|c|c|c|c|c|c|}
\hline & $\begin{array}{r}\text { Sales } \\
\leq=\$ 10 \mathrm{M} \\
\end{array}$ & MSA & $\begin{array}{l}\text { MSA \& Sales } \\
<=\$ 10 \mathrm{M}\end{array}$ & $\begin{array}{c}\text { Binary } \\
\text { HHI }\end{array}$ & Unweighted \\
\hline \multicolumn{6}{|c|}{ Majority Ownership } \\
\hline AFAM & $\begin{array}{c}0.176 \\
(0.404)\end{array}$ & $\begin{array}{c}0.290 \\
(0.637)\end{array}$ & $\begin{array}{c}0.266 \\
(0.579)\end{array}$ & $\begin{array}{c}0.189 \\
(0.438)\end{array}$ & $\begin{array}{c}0.118 \\
(0.348)\end{array}$ \\
\hline HISPANIC & $\begin{array}{c}0.049 \\
(0.147)\end{array}$ & $\begin{array}{l}-0.249 \\
(-0.905)\end{array}$ & $\begin{array}{l}-0.270 \\
(-0.958)\end{array}$ & $\begin{array}{c}0.057 \\
(0.172)\end{array}$ & $\begin{array}{c}0.082 \\
(0.269)\end{array}$ \\
\hline ASIAN & $\begin{array}{l}0.159 \\
(0.522)\end{array}$ & $\begin{array}{c}0.132 \\
(0.443)\end{array}$ & $\begin{array}{c}0.069 \\
(0.214)\end{array}$ & $\begin{array}{l}0.220 \\
(0.777)\end{array}$ & $\begin{array}{c}0.108 \\
(0.371)\end{array}$ \\
\hline FEMALE & $\begin{array}{c}-0.273 \\
(-1.317)\end{array}$ & $\begin{array}{l}-0.249 \\
(-1.032)\end{array}$ & $\begin{array}{l}-0.262 \\
(-1.042)\end{array}$ & $\begin{array}{l}-0.284 \\
(-1.397)\end{array}$ & $\begin{array}{l}-0.152 \\
(-1.071)\end{array}$ \\
\hline \multicolumn{6}{|c|}{ Market structure } \\
\hline $\mathrm{HHI}$ & $\begin{array}{c}1.411 \\
(1.612)\end{array}$ & $\begin{array}{l}1.065 \\
(0.753)\end{array}$ & $\begin{array}{l}1.125 \\
(0.754)\end{array}$ & $\begin{array}{c}0.182 \\
(1.118)\end{array}$ & $\begin{array}{c}0.724 \\
(1.265)\end{array}$ \\
\hline
\end{tabular}

\begin{tabular}{|c|c|c|c|c|c|}
\hline $\mathrm{ASN} * \mathrm{HHI}$ & & & & & \\
\hline $\mathrm{FML} \star \mathrm{HHI}$ & & & & & \\
\hline Financial Chara & cteristics & & & & \\
\hline ASSETS & $\begin{array}{c}0.048 \\
(0.472)\end{array}$ & $\begin{array}{c}0.033 \\
(0.307)\end{array}$ & $\begin{array}{c}0.024 \\
(0.201)\end{array}$ & $\begin{array}{c}0.052 \\
(0.557)\end{array}$ & $\begin{array}{l}-0.028 \\
(-0.425)\end{array}$ \\
\hline EMP LOY & $\begin{array}{l}-0.096 \\
(-1.083)\end{array}$ & $\begin{array}{l}-0.072 \\
(-0.749)\end{array}$ & $\begin{array}{l}-0.059 \\
(-0.580)\end{array}$ & $\begin{array}{l}-0.098 \\
(-1.175)\end{array}$ & $\begin{array}{l}-0.089 \\
(-1.487)\end{array}$ \\
\hline SALEASST & $\begin{array}{c}0.000 \\
(0.005)\end{array}$ & $\begin{array}{c}0.014 \\
(0.994)\end{array}$ & $\begin{array}{c}0.013 \\
(0.912)\end{array}$ & $\begin{array}{c}0.000 \\
(0.051)\end{array}$ & $\begin{array}{l}-0.003 \\
(-0.487)\end{array}$ \\
\hline LIABASST & $\begin{array}{l}0.238 * * \star \\
(2.601)\end{array}$ & $\begin{array}{l}-0.024 \\
(-0.218)\end{array}$ & $\begin{array}{l}-0.018 \\
(-0.156)\end{array}$ & $\begin{array}{l}0.241^{\star \star} \\
(2.569)\end{array}$ & $\begin{array}{c}0.140 \\
(1.525)\end{array}$ \\
\hline PROFASST & $\begin{array}{l}-0.005 \\
(-0.233)\end{array}$ & $\begin{array}{l}-0.032 \\
(-1.110)\end{array}$ & $\begin{array}{l}-0.039 \\
(-1.241)\end{array}$ & $\begin{array}{l}-0.004 \\
(-0.184)\end{array}$ & $\begin{array}{c}0.010 \\
(0.590)\end{array}$ \\
\hline Credit History & & & & & \\
\hline BANKRUP T & $\begin{array}{c}0.427 \\
(0.761)\end{array}$ & $\begin{array}{c}0.498 \\
(0.913)\end{array}$ & $\begin{array}{c}0.456 \\
(0.772)\end{array}$ & $\begin{array}{c}0.434 \\
(0.838)\end{array}$ & $\begin{array}{c}0.717 \\
(1.439)\end{array}$ \\
\hline PDELINQ1 & $\begin{array}{l}-1.744 \star \star \\
(-2.328)\end{array}$ & $\begin{array}{l}-2.044 \star \star \\
(-2.278)\end{array}$ & $\begin{array}{l}-2.134 * \star \\
(-2.366)\end{array}$ & $\begin{array}{l}-1.663 * \star \\
(-2.206)\end{array}$ & $\begin{array}{l}-0.670 \\
(-1.544)\end{array}$ \\
\hline PDELINQ2 & $\begin{array}{c}0.253 \\
(0.566)\end{array}$ & $\begin{array}{l}-0.043 \\
(-0.086)\end{array}$ & $\begin{array}{l}-0.087 \\
(-0.169)\end{array}$ & $\begin{array}{c}0.260 \\
(0.597)\end{array}$ & $\begin{array}{l}0.747 * \\
(1.649)\end{array}$ \\
\hline PDELINQ3 & $\begin{array}{l}-0.311 \\
(-0.872)\end{array}$ & $\begin{array}{l}-0.527 \\
(-1.320)\end{array}$ & $\begin{array}{l}-0.662 \star \\
(-1.663)\end{array}$ & $\begin{array}{l}-0.214 \\
(-0.596)\end{array}$ & $\begin{array}{c}0.176 \\
(0.595)\end{array}$ \\
\hline BDELINQ1 & $\begin{array}{c}0.068 \\
(0.112)\end{array}$ & $\begin{array}{c}0.151 \\
(0.246)\end{array}$ & $\begin{array}{c}0.129 \\
(0.204)\end{array}$ & $\begin{array}{c}0.079 \\
(0.134)\end{array}$ & $\begin{array}{l}-0.058 \\
(-0.157)\end{array}$ \\
\hline BDELINQ2 & $\begin{array}{l}-0.657^{\star} \\
(-1.755)\end{array}$ & $\begin{array}{l}-0.600 \\
(-1.407)\end{array}$ & $\begin{array}{l}-0.648 \\
(-1.447)\end{array}$ & $\begin{array}{l}-0.608^{\star} \\
(-1.699)\end{array}$ & $\begin{array}{l}-0.137 \\
(-0.308)\end{array}$ \\
\hline BDELINQ3 & $\begin{array}{l}-0.086 \\
(-0.361)\end{array}$ & $\begin{array}{c}0.009 \\
(0.036)\end{array}$ & $\begin{array}{l}-0.024 \\
(-0.089)\end{array}$ & $\begin{array}{l}-0.051 \\
(-0.220)\end{array}$ & $\begin{array}{l}-0.034 \\
(-0.235)\end{array}$ \\
\hline JUDGMENT & $\begin{array}{c}0.557 \\
(0.628)\end{array}$ & $\begin{array}{c}0.502 \\
(0.550)\end{array}$ & $\begin{array}{c}0.648 \\
(0.651)\end{array}$ & $\begin{array}{c}0.414 \\
(0.501)\end{array}$ & $\begin{array}{c}0.569 \\
(1.335)\end{array}$ \\
\hline $\begin{array}{l}\text { Credit Score } \\
\text { CREDSCR }\end{array}$ & $\begin{array}{l}-0.010 * \star \star \\
(-3.711)\end{array}$ & $\begin{array}{l}-0.011 * \star \star \\
(-3.489)\end{array}$ & $\begin{array}{l}-0.011 * \star \star \\
(-3.438)\end{array}$ & $\begin{array}{l}-0.010 * \star \star \\
(-3.680)\end{array}$ & $\begin{array}{l}-0.006 * * \star \\
(-3.608)\end{array}$ \\
\hline $\begin{array}{l}\text { Number of obs } \\
\text { F-statistic } \\
\text { Adjusted R2 }\end{array}$ & $\begin{array}{l}1364 \\
3.37 \star \star \star \\
0.21\end{array}$ & $\begin{array}{l}1331 \\
3.14 \star \star \star \\
0.25\end{array}$ & $\begin{array}{l}1055 \\
2.94 \star \star \star \\
0.24\end{array}$ & $\begin{array}{l}1682 \\
3.58 * \star \star \\
0.21\end{array}$ & $\begin{array}{l}1682 \\
6.46 * \star \star \\
0.21\end{array}$ \\
\hline
\end{tabular}

Other variables included in the analysis are: FIN_JBNK, REL_JBNK, CCORP, SCORP, PARTNER, LNAGE2, FRANCHIS, D6_NATN, D6_OUTSD, D6_REG, CHECKING, SAVING, NOT_HS, COLLEGE, EXPER, MANAGE, OWNSHR, TCUSE, IND_1, IND_3 - IND_9, MSA, REGION2 - REGION9, BONDSPRD, TERMPREM, MRL_INDX, FIXED, PCOL, BCOL, GUAR, MRL_LOC, MRL_LEAS, MRL_MRTG, MRL_MV, MRL_OTH, LEND_SRC, LOAN4, MRL_9394, MRL_PRIM, EDENĀLL, INVMĀT, LNAMTBRR, POINTS, FEE_AMT 
Table B-4 - Model 4

Dependent Variable: IntRate: Interest on Most Recent Loan. Robustness Checks

$\begin{array}{ccccc}\begin{array}{c}\text { Sales } \\ \leq=\$ 10 \mathrm{M}\end{array} & \text { MSA } & \begin{array}{c}\text { MSA \& Sales } \\ <=\$ 10 \mathrm{M}\end{array} & \begin{array}{c}\text { Binary } \\ \mathrm{HHI}\end{array} & \text { Unweighted }\end{array}$

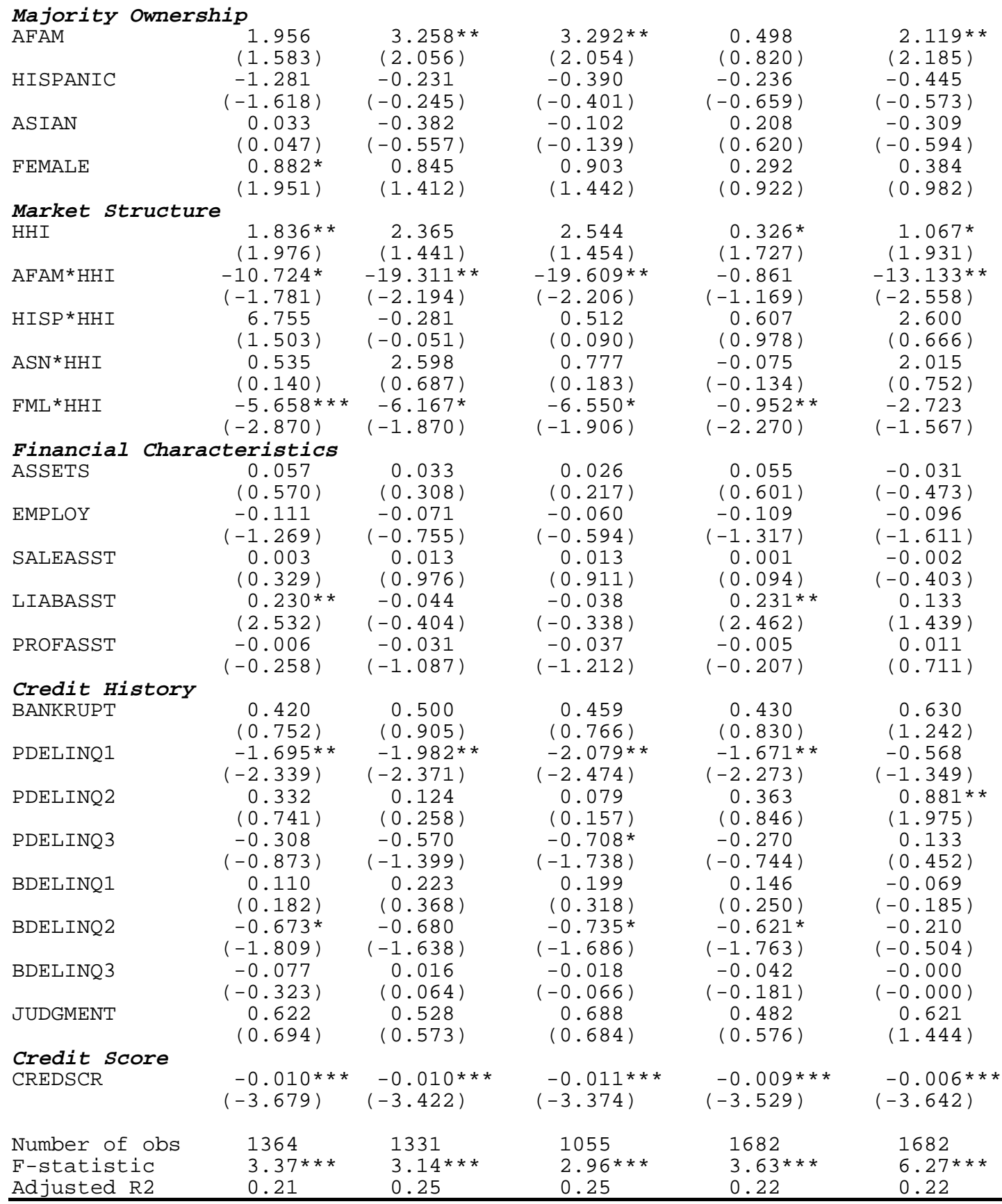

Other variables included in the analysis are: FIN_JBNK, REL_JBNK, CCORP, SCORP, PARTNER, LNAGE2, FRANCHIS, D6_NATN, D6_OUTSD, D6_REG, CHECKING, SAVING, NOT_HS, COLLEGE, EXPER, MANAGE, OWNSHR, TCUSE, IND_1, IND_3 - IND_9, MSA, REGION2 - REGION9, BONDSPRD, TERMPREM, MRL_INDX, FIXED, PCOL, BCOL, GUAR, MRL_LOC, MRL_LEAS, MRL_MRTG, MRL_MV, MRL_OTH, LEND_SRC, LOAN4, MRL_9394, MRL_PRIM, EDENĀLL, INVMĀT, LNAMTBRR, POINTS, FEE_AMT 


\section{Appendix C \\ Statistical Controls}

\section{Firm Characteristics:}

Financial indicators of firm risk. According to Foster (1986), financial indicators of firm risk are especially important in the loan granting decision. Gibson (1983) surveys lending institutions and finds that the debt-to-asset ratio is one of the most prevalent ratios that banks use to evaluate firm risk. We include LIABASST, the ratio of debt to total assets, in each of our analyses.

Firm profits. Profit controls for a firm's ability to generate internal funds and its demand for external funds, in addition to firm specific risk. As such, Myers and Majluf (1984) and Munnell et al. (1996), suggest that profits play a key role in the credit process. We include PROFASST, the ratio of operating profits to total assets in each aspect of our analysis and SALEASST, the ratio of sales to total assets. ${ }^{36}$

Firm size. A number of theories (e.g., Jovanovic, 1982) and empirical studies (e.g., Evans, 1987) suggest that firm behavior changes with firm size. We use the log of the firm's total assets (LNASSET) and the log of the number of full time equivalent employees (LNTOTEMP) to measure firm size.

Firm age. Foster (1986) argues that information about the client can be critical in assessing the probability of default on a loan. The age of a firm can act as a proxy for the amount of information available on the firm, and thus the ability to evaluate a firm's credit history, a factor stressed by creditors (Munnell et al., 1996). In addition, Dennis, Dunkelberg, and Van Hulle (1988) find that young firms tend to pay higher interest rates on loans than other firms. We include the natural log of firm age (LNAGE, LNAGE2) in years in each aspect of our analysis. ${ }^{37}$

Banking Relationships. Strong relationships between banks and small businesses have been shown to increase the availability of funds and reduce the cost of capital to small businesses (Petersen and Rajan, 1994; Berger and Udell, 1995). These relationships also provide banks with relatively easy access to information on the credit history of the firm. Because relationship lending

\footnotetext{
${ }^{36}$ We test the specification of PROFASST with PROFINT, defined as operating profits and interest expense relative to total assets, in our robustness checks. Including interest expense in the numerator of our profit measure controls for differences in profitability due to differences in capital structure across firms (Foster, 1986, p 67). Our results were insensitive to this alternative specification.

${ }^{37}$ Where appropriate, we adjust LNAGE to reflect the age of the firm at the particular event date. For example, in the analyses that focus on the most recent loan, we define age of the firm at the time of the most recent loan, rather than the survey date (LNAGE2).
} 
has been shown to be an important characteristic in small business lending, it is possible that differences in behavior across demographic groups are attributable to differences in relationships. We include the length of the relationship with the firm's primary lending institution (REL_PRIM) along with the number of institutions that the firm uses (SOURCES) to control for cross-sectional differences in the strength of these relationships. For the denial and interest rate models, we use the length of the relationship with the lender for the most recent loan (REL_JBNK) and the number of distinct lending sources that the firm uses (LEND_SRC) to measure relationship strength with the creditor. ${ }^{38}$ Finally, we include indicator variables on whether the firm had any checking (CHECKING) or savings (SAVING) accounts.

Relationships with Suppliers. A firm's relationship with its suppliers helps to characterize its demand for credit and may provide information about a firm's credit worthiness to banks (Petersen and Rajan, 1994). We include whether the firm uses trade credit (TCUSE). We also make cautious use of DENTC, which equals one if a firm has been denied trade credit in the last three years, and zero otherwise. This variable can act as a signal to lenders that a firm may face serious cash-flow problems. The variable also has the ability to capture economically relevant information that may be observed both by suppliers and lenders, but is unavailable to researchers. But because the variable is not a direct measure of firm performance, it may also reflect discriminatory treatment on the part of suppliers. Moreover, to the extent that suppliers and lending institutions consider many of the same fundamental factors in their assessment of the credit worthiness of firms, DENTC undercuts our ability to get a precise measure of the influence of these underlying factors on firm experiences in credit markets. Because of the ambiguous role played by this variable, we estimate our equations with and without this variable.

\section{Owner Characteristics:}

We control for a variety of owner characteristics including the percentage of ownership of the principal owner (OWNSHR), the years of managerial experience of the owner (EXPER), the education level of the owner (NOT_HS, COLLEGE), where NOT_HS indicates that the owner does not hold a high school degree and COLLEGE indicates that the owner has at least some

\footnotetext{
${ }^{38}$ The 'length of relationship' variables are adjusted to reflect the relationship length at the time of the particular event, such as the date of the most recent loan (RELPRIM2). Relationship length is defined on the data set only for financial institutions. Firms with no relationship with financial institutions were set to zero and a shift term was included to identify these observations.
} 
college credit. In addition, we include a control variable (MANAGE) that we set equal to one if the firm is owner-managed, zero otherwise.

\section{Credit History:}

Self Reported Information. A firm's credit history may be the most important indicator of firm risk (Foster, 1986; Munnell et al., 1996). NSSBF provides us with multiple measures of firm credit history, none of which have been available to past researchers. These variables are of particular interest because they are commonly used in credit-scoring models. BANKRUPT is an indicator variable that is set equal to one if the firm or its principal owner declared bankruptcy within the past seven years, and zero otherwise. A set of 6 indicator variables, PDELINQ1-3, BDELINQ1-3 are set equal to one if the principal owner (firm) has been delinquent on one, two, or three or more personal (business) obligations in excess of 60 days within the past three years. We also include the variable JUDGMENT, equal to one if there have been any judgements rendered against the principal owner within the past three years.

External Information. We supplement the NSSBF with credit scores from Dun and Bradstreet. D\&B provides credit scores and evaluations on privately held companies in much the same way that Standard and Poor's or Moody's provide credit ratings on publicly held corporations. Banks can purchase this information from D\&B to augment or verify information on loan applications. (Firms also may be aware of their D\&B credit score). CREDSCR is an overall evaluation of the firm's credit worthiness that ranges from zero to one hundred (one hundred being the best) at year-end 1993. ${ }^{39}$ Because this is a constructed variable that likely considers many of the firm attributes and credit history information already contained in our model, we estimate equations with and without this variable. This approach allows us to observe the full effect of the underlying factors that influence credit market experiences.

\section{Loan Characteristics:}

We expect interest rates to be sensitive to market conditions at the time of the loan and the characteristics of the loan. ${ }^{40}$ MRL_INDX is equal to the prime rate at the time of issue of the loan

\footnotetext{
${ }^{39}$ Because of potential concerns with the independence of credit quality and market structure, we examine the relationship between the D\&B credit score (CREDSCR) and the level of bank competition (HHI). Although these variables are correlated, the correlation coefficient is only .0567. A regression model of HHI and CREDSCR predicts that a 100 percentage point increase in the CREDSCR variable (a change that spans the range of CREDSCR) is associated with only a .02132 increase in HHI.

${ }^{40}$ Some, but not all, of the variables in this section are also appropriate for the denied most recent loan analysis. See Table 8 .
} 
for fixed rate loans, or the rate of the appropriate index for variable rate loans. ${ }^{41}$ POINTS is the number of percentage points the firm had to pay to close the loan. FEE_AMT is the ratio of fees to the amount borrowed. ${ }^{42}$ FIXED equals one if the interest rate is fixed, zero otherwise. TERMPREM is defined as the yield on a government bond with a maturity similar to the firm's loan, minus the treasury bill yield (Petersen and Rajan, 1994). INVMAT is the inverse of the maturity of the loan (in months). LNAMTBRR is the natural $\log$ of the amount borrowed; it controls for the size of the loan. BONDSPRD is a small firm premium defined as the difference between the yield on Moody's corporate bonds rated BAA and the yield on ten year government bonds at the time of the loan (Petersen and Rajan, 1994). FIN_JBNK equals one if the most recent loan came from any financial institution, zero otherwise. GUAR equals one if the firm was required to have a personal guaranty, cosigner, or other guarantor for the most recent loan. Two indicator variables control for a requirement for business (BCOL) or personal (PCOL) collateral. Finally, we include a set of controls for type of loan, including line of credit, lease, mortgage, motor vehicle, or other, with equipment loans acting as the omitted loan type. ${ }^{43}$

\section{Market Characteristics:}

Because small businesses tend to do their banking locally rather than nationally, we are able to use cross-sectional data to compare lending practices across banking markets. We supplement the NSSBF data set with the Herfindahl-Hirschman Index (HHI) for each county or metropolitan statistical area in which the firm's headquarters is located. The measure is computed based on June 1993 FDIC summary of deposit data and ranges from one to $10,000 .^{44}$ We rescale this index, placing it on a zero to one scale to ease interpretability. The rescaled mean value of $\mathrm{HHI}$ in the banking markets used by small businesses in our data set is 0.2018 , and ranges from 0.0661 to 0.8215 in MSAs and from 0.1005 to 1 in non-metropolitan areas. We also control for MSA and

\footnotetext{
${ }^{41}$ In practice, many of the variable rate loans were also tied to the prime, making 80 percent of these values the prime rate.

${ }^{42}$ Due to the presence of outliers, POINTS and FEE_AMT were Winsorized at the 99th percentile (Andrews, et. al, 1972).

${ }^{43}$ Other loan variables related to the most recent loan include J5_ASST, the size of the firm's loan request relative to assets to control for the reasonableness of the request (only for DenMRL analysis), MRL_PRIM to control for whether the most recent loan was with the firm's primary institution, and MRL_9394, to control for whether the loan was granted in either 1993 or 1994.

${ }^{44}$ Robustness checks included using an indicator variable for HHI, with both 0.1800 and 0.2300 cut-offs, in addition to the $\log$ of HHI.
} 
rural counties.

Other controls:

In addition, we control for industry specific differences, ${ }^{45}$ organizational form (PROP, PARTNER, SCORP, CCORP, FRANCHIS; see Cavalluzzo and Geczy, 1998), area of sales (D6_SAME，D6_REG，D6_NATN, and D6_OUTSD), and regional differences (REGION2REGION9).

Minority and Gender:

After controlling for relevant economic factors, the analyses control for race (AFAM and ASIAN), ethnicity (HISPAN), gender (FEMALE), and the interaction of each with commercial bank concentration (AFAM*HHI, ASN*HHI, HISP*HHI, FML*HHI). ${ }^{46}$ Implicit in the model specification is the comparison to businesses owned by white-males.

\footnotetext{
${ }^{45}$ The models use nine industry groups (IND_1-IND_9).

${ }^{46}$ We also estimated separate minority female indicators and interactions with HHI. There was no evidence of separate minority female effects.
} 


\section{Appendix D \\ Joint Tests of Significance for Demographic, HHI, and Demographic interaction Variables}

\section{Panel A: Main Models}

Apply
\begin{tabular}{|l|l|l|l|l|l|} 
Apdel 1 & \multicolumn{1}{c}{ Model 2 } & \multicolumn{1}{c}{ Model 3 } & --- & Model 5 \\
\hline Herf & --- & --- & --- & -- \\
\hline Main Race (4) & $*$ & $*$ & $*$ & --- & --- \\
\hline Race Int (4) & NA & NA & NA & --- & --- \\
\hline Black (1/2) & --- & --- & --- & -- & \\
\hline Hispan (1/2) & --- & --- & --- & --- & --- \\
\hline Asian (1/2) & $* * *$ & $* *$ & $* *$ & $* *$ & $* *$ \\
\hline Women (1/2) & --- & --- & -- & --- & --- \\
\hline
\end{tabular}

\begin{tabular}{|c|c|c|c|c|c|}
\hline Fear & Model 1 & Model 2 & Model 3 & Model 4 & Model 5 \\
\hline Herf & --- & --- & --- & --- & --- \\
\hline Main Race (4) & $* * *$ & $* * *$ & $* * *$ & --- & --- \\
\hline Race Int (4) & $\mathrm{NA}$ & $\mathrm{NA}$ & NA & --- & --- \\
\hline Black (1/2) & $* * *$ & $* * *$ & $* * *$ & $* * *$ & $* * *$ \\
\hline Hispan $(1 / 2)$ & $* * *$ & $* *$ & $* *$ & $* *$ & $* *$ \\
\hline Asian (1/2) & --- & --- & --- & --- & --- \\
\hline Women $(1 / 2)$ & --- & --- & --- & --- & --- \\
\hline
\end{tabular}

\begin{tabular}{|c|c|c|c|c|c|}
\hline EverDen & Model 1 & Model 2 & Model 3 & Model 4 & Model 5 \\
\hline Herf & --- & --- & --- & $*$ & $*$ \\
\hline Main Race (4) & $* * *$ & $* * *$ & $* * *$ & $* *$ & $*$ \\
\hline Race Int (4) & NA & NA & NA & $* * *$ & $* * *$ \\
\hline Black (1/2) & $* * *$ & $* * *$ & $* * *$ & $* * *$ & $* * *$ \\
\hline Hispan $(1 / 2)$ & --- & --- & --- & --- & --- \\
\hline Asian $(1 / 2)$ & $*$ & --- & --- & --- & --- \\
\hline Women $(1 / 2)$ & --- & --- & $\begin{array}{ll}-- \\
\end{array}$ & $* * *$ & $* *$ \\
\hline
\end{tabular}

\begin{tabular}{|c|c|c|c|c|c|}
\hline EverDen2 & Model 1 & Model 2 & Model 3 & Model 4 & Model 5 \\
\hline Herf & --- & --- & --- & --- & --- \\
\hline Main Race (4) & $* * *$ & $* * *$ & $* * *$ & $* * *$ & $* * *$ \\
\hline Race Int (4) & NA & $\mathrm{NA}$ & $\mathrm{NA}$ & $* * *$ & $* * *$ \\
\hline Black (1/2) & $* * *$ & $* * *$ & $* * *$ & $* * *$ & $* * *$ \\
\hline Hispan $(1 / 2)$ & $* *$ & ** & $* *$ & $*$ & $*$ \\
\hline Asian (1/2) & $* * *$ & $* * *$ & $* *$ & $* *$ & $* *$ \\
\hline Women $(1 / 2)$ & --- & --- & --- & $* * *$ & $* * *$ \\
\hline
\end{tabular}

KEY: * (10\%);**(5\%); ***(1\%); NA - not applicable; --- p level >0.10; AFAM, HISPAN, ASIAN, FEMALE either 1 (for models 1-3) or 2 (models 4,5) degrees of freedom. 


\section{Panel A: Main Models - continued}

\begin{tabular}{|c|c|c|c|c|c|}
\hline DenMRL & Model 1 & Model 2 & Model 3 & Model 4 & Model 5 \\
\hline Herf & --- & --- & --- & --- & --- \\
\hline Main Race (4) & $* * *$ & $*$ & --- & $* *$ & $* *$ \\
\hline Race Int (4) & NA & NA & $\mathrm{NA}$ & $* * *$ & $* * *$ \\
\hline Black (1/2) & $* * *$ & $* * *$ & $* *$ & $* *$ & $* *$ \\
\hline Hispan $(1 / 2)$ & --- & --- & --- & --- & --- \\
\hline Asian (1/2) & --- & --- & --- & $* *$ & $*$ \\
\hline Women $(1 / 2)$ & --- & --- & --- & $* * *$ & $* *$ \\
\hline
\end{tabular}

IntRate
\begin{tabular}{|l|l|l|l|l|l|}
\hline Herf & Model 1 & Model 2 & \multicolumn{1}{l}{ Model 3 } & Model 4 & $*$ \\
\hline Main Race (4) & --- & -- & --- & $*$ & $*$ \\
\hline Race Int (4) & NA & --- & --- & $* * *$ & $* * *$ \\
\hline Black (1/2) & NA & NA & --- & --- & --- \\
\hline Hispan (1/2) & --- & --- & --- & --- & --- \\
\hline Asian (1/2) & --- & --- & --- & --- & --- \\
\hline Women (1/2) & --- & --- & --- & $* * *$ & $* * *$ \\
\hline
\end{tabular}

Panel B: Line of Credit Analysis

\begin{tabular}{|c|c|c|c|c|}
\hline & HaveLOC & ApplyLOC & DenLOC & RateLOC \\
\hline Herf & --- & --- & --- & --- \\
\hline Main Race (4) & --- & --- & --- & --- \\
\hline Race Int (4) & * & NA & $* *$ & --- \\
\hline Black (1/2) & --- & --- & $* * *$ & --- \\
\hline Hispan (1/2) & $*$ & --- & --- & $*$ \\
\hline Asian (1/2) & $* * *$ & $* *$ & --- & --- \\
\hline Women (1/2) & $*$ & --- & --- & --- \\
\hline
\end{tabular}

Panel C: Have Loan, full sample

\begin{tabular}{|c|c|c|c|c|c|}
\hline & Model 1 & Model 2 & Model 3 & Model 4 & Model 5 \\
\hline Herf $(1 / 5)$ & --- & --- & --- & --- & --- \\
\hline Main Race (4) & --- & --- & --- & --- & --- \\
\hline Race Int (4) & NA & NA & NA & --- & --- \\
\hline Black (1/2) & $\begin{array}{ll}-- \\
\end{array}$ & --- & $\begin{array}{ll}-- \\
\end{array}$ & --- & --- \\
\hline Hispan (1/2) & --- & --- & --- & --- & --- \\
\hline Asian (1/2) & $*$ & $*$ & $*$ & --- & --- \\
\hline Women $(1 / 2)$ & --- & --- & --- & --- & --- \\
\hline
\end{tabular}

KEY: * (10\%); ** (5\%);***(1\%); NA - not applicable; --- p level >0.10; AFAM, HISPAN, ASIAN, FEMALE either 1 (for models 1-3) or 2 (models 4,5) degrees of freedom. 


\section{Panel D: Robustness Checks}

\begin{tabular}{|c|c|c|c|c|c|}
\hline EverDen & $<\$ 10$ Mil & MSA & MSA $\&<\$ 10 M$ & Binary HHI & Unweighted \\
\hline Herf (1/5) & $*$ & --- & --- & --- & --- \\
\hline Main Race (4) & $*$ & --- & --- & $*$ & --- \\
\hline Race Int (4) & $* * *$ & --- & --- & --- & --- \\
\hline Black (1/2) & $* * *$ & $* *$ & $* * *$ & $* * *$ & $* * *$ \\
\hline Hispan $(1 / 2)$ & --- & --- & --- & --- & --- \\
\hline Asian $(1 / 2)$ & --- & --- & --- & --- & $* *$ \\
\hline Women $(1 / 2)$ & $* *$ & $*$ & $*$ & --- & $*$ \\
\hline
\end{tabular}

\begin{tabular}{|c|c|c|c|c|c|}
\hline EverDen2 & $<\$ 10$ Mil & MSA & MSA $\&<\$ 10 M$ & Binary HHI & Unweighted \\
\hline Herf $(1 / 5)$ & --- & --- & --- & --- & --- \\
\hline Main Race (4) & $* * *$ & $* *$ & $*$ & $* *$ & $* *$ \\
\hline Race Int (4) & $* * *$ & --- & --- & --- & * \\
\hline Black (1/2) & $* * *$ & $* * *$ & $* * *$ & $* * *$ & $* * *$ \\
\hline Hispan $(1 / 2)$ & $*$ & --- & --- & $*$ & $* * *$ \\
\hline Asian (1/2) & $* *$ & $* *$ & $* *$ & $* *$ & $* * *$ \\
\hline Women $(1 / 2)$ & $* * *$ & $* *$ & $*$ & --- & * \\
\hline
\end{tabular}

\begin{tabular}{|c|c|c|c|c|c|}
\hline DenMRL & $<\$ 10$ Mil & MSA & MSA $\&<\$ 10 M$ & Binary HHI & Unweighted \\
\hline Herf (1/5) & --- & --- & --- & --- & --- \\
\hline Main Race (4) & $* *$ & $* *$ & $* *$ & --- & $* * *$ \\
\hline Race Int (4) & $* * *$ & $* * *$ & $* * *$ & $*$ & $* * *$ \\
\hline Black (1/2) & $* *$ & $*$ & $*$ & $* *$ & $* * *$ \\
\hline Hispan $(1 / 2)$ & --- & --- & --- & --- & --- \\
\hline Asian (1/2) & $* *$ & $*$ & --- & --- & $* * *$ \\
\hline Women $(1 / 2)$ & $* * *$ & $* *$ & $* *$ & --- & $* *$ \\
\hline
\end{tabular}

\begin{tabular}{|c|c|c|c|c|c|}
\hline IntRATE & $<\$ 10$ Mil & MSA & $M S A \&<\$ 10 M$ & Binary HHI & Unweighted \\
\hline Herf (1/5) & $* *$ & -- & -- & $*$ & $*$ \\
\hline Main Race (4) & $* *$ & --- & --- & --- & $*$ \\
\hline Race Int (4) & $* * *$ & $* *$ & $* *$ & $\begin{array}{ll}-- \\
\end{array}$ & $* *$ \\
\hline Black (1/2) & --- & $*$ & $*$ & --- & $* *$ \\
\hline Hispan $(1 / 2)$ & --- & --- & --- & --- & --- \\
\hline Asian (1/2) & --- & --- & --- & --- & --- \\
\hline Women $(1 / 2)$ & $* * *$ & --- & --- & $* *$ & --- \\
\hline
\end{tabular}

KEY: * (10\%); ** (5\%);***(1\%); NA - not applicable; --- p level >0.10; AFAM, HISPAN, ASIAN, FEMALE either 1 (for models 1-3) or 2 (models 4,5) degrees of freedom. 


\section{Appendix E \\ Estimated Coefficients for Model 4 of Main Models}

Apply: Firm applied for a loan or line of credit within the past three years

Survey logistic regression

$\begin{array}{ll}\text { pweight: } & \text { new_wgt } \\ \text { Strata: } & \text { newstrat } \\ \text { PSU: } & \text { <observations> }\end{array}$

$\begin{array}{llr}\text { Number of obs } & = & 4570 \\ \text { Number of strata } & = & 65 \\ \text { Number of PSUs } & = & 4570 \\ \text { Population size } & = & 4.898 e+08 \\ \text { F(59, 4447) } & = & 8.98 \\ \text { Prob }>\text { F } & = & 0.0000\end{array}$

\begin{tabular}{|c|c|c|c|c|c|c|}
\hline apply & Coef. & Std. Err. & t & $P>|t|$ & [95\% Conf. & Interval] \\
\hline afam & .437691 & .3110838 & 1.407 & 0.160 & -.1721858 & 1.047568 \\
\hline hispan & -.024881 & .314299 & -0.079 & 0.937 & -.6410612 & .5912992 \\
\hline asian & -.4668187 & .3218934 & -1.450 & 0.147 & -1.097888 & .1642502 \\
\hline female & -.1060071 & .2408804 & -0.440 & 0.660 & -.5782508 & .3662366 \\
\hline hhi & -.2557543 & .5466889 & -0.468 & 0.640 & -1.327533 & .8160241 \\
\hline $\operatorname{afam} * h h i$ & -2.137582 & 1.598938 & -1.337 & 0.181 & -5.272285 & .9971212 \\
\hline hisp*hhi & .643577 & 1.390289 & 0.463 & 0.643 & -2.082071 & 3.369225 \\
\hline $\operatorname{asn} * h h i$ & .032049 & 1.469993 & 0.022 & 0.983 & -2.849858 & 2.913956 \\
\hline $\mathrm{fml} * \mathrm{hhi}$ & .0461582 & 1.017296 & 0.045 & 0.964 & -1.94824 & 2.040557 \\
\hline Inasset & .282212 & .0377972 & 7.466 & 0.000 & .2081109 & .3563132 \\
\hline Intotemp & .1139479 & .0503178 & 2.265 & 0.024 & .0153003 & .2125955 \\
\hline saleasst & -.0000938 & .00423 & -0.022 & 0.982 & -.0083867 & .0081992 \\
\hline liabasst & .2407888 & .0818834 & 2.941 & 0.003 & .0802572 & .4013204 \\
\hline profasst & .0024224 & .0138423 & 0.175 & 0.861 & -.0247153 & .0295601 \\
\hline bankrupt & .0047225 & .2997699 & 0.016 & 0.987 & -.5829734 & .5924185 \\
\hline pdeling1 & -.5352452 & .2960199 & -1.808 & 0.071 & -1.115589 & .045099 \\
\hline pdeling2 & -.0171948 & .2935465 & -0.059 & 0.953 & -.59269 & .5583005 \\
\hline pdeling3 & .0642244 & .1859347 & 0.345 & 0.730 & -.3002989 & .4287477 \\
\hline bdeling1 & .0955051 & .241506 & 0.395 & 0.693 & -.3779652 & .5689754 \\
\hline bdeling2 & -.0474461 & .2257824 & -0.210 & 0.834 & -.4900904 & .3951982 \\
\hline bdeling3 & .2866027 & .1623432 & 1.765 & 0.078 & -.0316696 & .6048751 \\
\hline judgment & -.208374 & .2136198 & -0.975 & 0.329 & -.6271736 & .2104257 \\
\hline credscr & -.0007929 & .0016904 & -0.469 & 0.639 & -.0041069 & .0025212 \\
\hline prim_fin & .4926221 & .2919589 & 1.687 & 0.092 & -.0797606 & 1.065005 \\
\hline rel_prim & -.0118197 & .0072418 & -1.632 & 0.103 & -.0260173 & .0023778 \\
\hline ccorp & -.11537 & .1332528 & -0.866 & 0.387 & -.3766108 & .1458709 \\
\hline scorp & .1334588 & .1428032 & 0.935 & 0.350 & -.1465055 & .4134231 \\
\hline partner & -.1049939 & .2070371 & -0.507 & 0.612 & -.5108883 & .3009004 \\
\hline lnage & -.0225942 & .0792746 & -0.285 & 0.776 & -.1780113 & .1328229 \\
\hline franchis & -.1155504 & .2477877 & -0.466 & 0.641 & -.6013358 & .370235 \\
\hline d6_natn & .094225 & .1530574 & 0.616 & 0.538 & -.2058425 & .3942925 \\
\hline d6_outsd & -1.162642 & .3792758 & -3.065 & 0.002 & -1.906209 & -.4190756 \\
\hline d6_reg & .2070049 & .1022731 & 2.024 & 0.043 & .0064995 & .4075103 \\
\hline checking & .1545732 & .3575409 & 0.432 & 0.666 & -.5463825 & .8555288 \\
\hline saving & -.0238947 & .1048368 & -0.228 & 0.820 & -.2294262 & .1816368 \\
\hline not_hs & -.1964095 & .2647934 & -0.742 & 0.458 & -.7155346 & .3227155 \\
\hline college & .274572 & .1096468 & 2.504 & 0.012 & .0596104 & .4895336 \\
\hline exper & -.0138119 & .0050018 & -2.761 & 0.006 & -.0236179 & -.004006 \\
\hline manage & .1517527 & .118986 & 1.275 & 0.202 & -.0815183 & .3850236 \\
\hline ownshr & .00062 & .0020939 & 0.296 & 0.767 & -.0034851 & .0047251 \\
\hline tcuse & .3815513 & .0982086 & 3.885 & 0.000 & .1890142 & .5740884 \\
\hline
\end{tabular}




\begin{tabular}{|c|c|c|c|c|c|c|}
\hline ind_1 & .2674217 & .2324698 & 1.150 & 0.250 & -.1883331 & .7231765 \\
\hline ind_3 & -.0478625 & .2811349 & -0.170 & 0.865 & -.5990249 & .5032999 \\
\hline ind_4 & .0989348 & .3109191 & 0.318 & 0.750 & -.5106192 & .7084888 \\
\hline ind_5 & .1422572 & .2435276 & 0.584 & 0.559 & -.3351764 & .6196908 \\
\hline ind_6 & -.0120587 & .2214486 & -0.054 & 0.957 & -.4462066 & .4220892 \\
\hline ind_7 & -.2965544 & .2666058 & -1.112 & 0.266 & -.8192325 & .2261237 \\
\hline ind_8 & -.0059705 & .2235739 & -0.027 & 0.979 & -.4442851 & .4323441 \\
\hline ind_9 & .055153 & .2269301 & 0.243 & 0.808 & -.3897414 & .5000474 \\
\hline $\mathrm{msa}$ & -.5581457 & .1361127 & -4.101 & 0.000 & -.8249935 & -.291298 \\
\hline region2 & .0964751 & .2185933 & 0.441 & 0.659 & -.332075 & .5250252 \\
\hline region 3 & -.4223352 & .1613907 & -2.617 & 0.009 & -.7387401 & -.1059304 \\
\hline region 4 & -.1126265 & .2113778 & -0.533 & 0.594 & -.5270307 & .3017777 \\
\hline region 5 & -.4368398 & .2067273 & -2.113 & 0.035 & -.8421267 & -.0315529 \\
\hline region 6 & -.5310731 & .1553083 & -3.419 & 0.001 & -.8355536 & -.2265927 \\
\hline region 7 & -.2736738 & .1513839 & -1.808 & 0.071 & -.5704606 & .0231129 \\
\hline region 8 & .0612844 & .180855 & 0.339 & 0.735 & -.29328 & .4158489 \\
\hline region 9 & .0068579 & .1770345 & 0.039 & 0.969 & -.3402165 & .3539324 \\
\hline sources & .3108031 & .0365586 & 8.502 & 0.000 & .2391303 & .3824759 \\
\hline _cons & -1.075657 & .5702322 & -1.886 & 0.059 & -2.193592 & .0422775 \\
\hline
\end{tabular}


FearDen: Firm did not apply, fearing denial Model 4

Survey logistic regression

$\begin{array}{ll}\text { pweight: } & \text { new_wgt } \\ \text { Strata: } & \text { newstrat } \\ \text { PSU: } & \text { <observations> }\end{array}$

$\begin{array}{llr}\text { Number of obs } & = & 2609 \\ \text { Number of strata } & = & 65 \\ \text { Number of PSUs } & = & 2609 \\ \text { Population size } & = & 2.392 e+08 \\ \text { F( 61, 2484) } & = & 6.71 \\ \text { Prob }>\text { F } & = & 0.0000\end{array}$

\begin{tabular}{|c|c|c|c|c|c|c|}
\hline fearden & Coef. & Std. Err. & $t$ & $P>|t|$ & [95\% Conf. & Interval] \\
\hline afam & .663036 & .5107544 & 1.298 & 0.194 & -.3385006 & 1.664573 \\
\hline hispan & 1.086219 & .5669278 & 1.916 & 0.055 & -.0254676 & 2.197906 \\
\hline asian & .5947314 & .7685041 & 0.774 & 0.439 & -.9122258 & 2.101689 \\
\hline female & -.5990599 & .3885196 & -1.542 & 0.123 & -1.360907 & .1627868 \\
\hline hhi & -.2001328 & 1.019738 & -0.196 & 0.844 & -2.199734 & 1.799469 \\
\hline $\operatorname{afam} * \mathrm{hhi}$ & 2.815516 & 2.724151 & 1.034 & 0.301 & -2.526262 & 8.157295 \\
\hline hisp*hhi & -1.885843 & 2.638341 & -0.715 & 0.475 & -7.059358 & 3.287673 \\
\hline $\operatorname{asn} \star h h i$ & -.5649416 & 3.899693 & -0.145 & 0.885 & -8.211837 & 7.081954 \\
\hline $\mathrm{fml} * \mathrm{hhi}$ & 2.756637 & 1.549034 & 1.780 & 0.075 & -.28086 & 5.794133 \\
\hline Inasset & -.3507682 & .0683359 & -5.133 & 0.000 & -.4847678 & -.2167686 \\
\hline Intotemp & -.0399073 & .0856508 & -0.466 & 0.641 & -.2078596 & .128045 \\
\hline saleasst & -.0099495 & .0058963 & -1.687 & 0.092 & -.0215115 & .0016125 \\
\hline liabasst & -.0255743 & .0906153 & -0.282 & 0.778 & -.2032615 & .1521129 \\
\hline profasst & -.0422923 & .0500403 & -0.845 & 0.398 & -.1404161 & .0558316 \\
\hline bankrupt & .8879008 & .3475789 & 2.555 & 0.011 & .2063345 & 1.569467 \\
\hline pdelinq1 & .7079629 & .3998376 & 1.771 & 0.077 & -.0760773 & 1.492003 \\
\hline pdelinq2 & -.0434857 & .4368206 & -0.100 & 0.921 & -.9000458 & .8130743 \\
\hline pdelinq3 & .9195927 & .2674246 & 3.439 & 0.001 & .3952005 & 1.443985 \\
\hline bdelinq1 & .2174668 & .3285251 & 0.662 & 0.508 & -.4267371 & .8616707 \\
\hline bdelinq2 & 1.69281 & .3586414 & 4.720 & 0.000 & .9895508 & 2.396068 \\
\hline bdeling3 & .9158672 & .1953573 & 4.688 & 0.000 & .5327918 & 1.298943 \\
\hline judgment & .7101421 & .3282621 & 2.163 & 0.031 & .0664539 & 1.35383 \\
\hline credscr & -.0096402 & .0025319 & -3.807 & 0.000 & -.0146051 & -.0046753 \\
\hline prim_fin & -.3344678 & .4846923 & -0.690 & 0.490 & -1.284899 & .6159638 \\
\hline rel_prim & -.0192434 & .0125831 & -1.529 & 0.126 & -.0439176 & .0054307 \\
\hline $\mathrm{ccorp}$ & .2726388 & .2254651 & 1.209 & 0.227 & -.169475 & .7147525 \\
\hline scorp & .2081743 & .2237087 & 0.931 & 0.352 & -.2304953 & .6468439 \\
\hline partner & -.1067405 & .3419467 & -0.312 & 0.755 & -.7772626 & .5637817 \\
\hline lnage & -.078308 & .1246236 & -0.628 & 0.530 & -.3226819 & .166066 \\
\hline franchis & .1970332 & .4466906 & 0.441 & 0.659 & -.678881 & 1.072947 \\
\hline d6_natn & .2976593 & .2404053 & 1.238 & 0.216 & -.1737506 & .7690692 \\
\hline d6_outsd & .4639853 & .4307478 & 1.077 & 0.282 & -.3806667 & 1.308637 \\
\hline d6_reg & .0171834 & .1605977 & 0.107 & 0.915 & -.2977321 & .332099 \\
\hline checking & .9218242 & .7713073 & 1.195 & 0.232 & -.5906298 & 2.434278 \\
\hline saving & -.3661318 & .1659895 & -2.206 & 0.027 & -.69162 & -.0406436 \\
\hline not_hs & .5146032 & .3855258 & 1.335 & 0.182 & -.2413731 & 1.27058 \\
\hline college & -.216263 & .1735881 & -1.246 & 0.213 & -.5566514 & .1241254 \\
\hline exper & .0081333 & .0079672 & 1.021 & 0.307 & -.0074896 & .0237562 \\
\hline manage & -.0748126 & .1849669 & -0.404 & 0.686 & -.4375137 & .2878885 \\
\hline ownshr & .0010889 & .0032923 & 0.331 & 0.741 & -.0053671 & .0075448 \\
\hline tcuse & -.0930439 & .1697563 & -0.548 & 0.584 & -.4259185 & .2398308 \\
\hline ind_1 & -.530223 & .4004996 & -1.324 & 0.186 & -1.315561 & .2551153 \\
\hline ind_3 & -.4084318 & .4176937 & -0.978 & 0.328 & -1.227486 & .4106224 \\
\hline ind_4 & -.0049359 & .4401732 & -0.011 & 0.991 & -.8680702 & .8581984 \\
\hline ind_5 & -.3861265 & .3908144 & -0.988 & 0.323 & -1.152473 & .3802202 \\
\hline ind_-6 & -.4227756 & .3752377 & -1.127 & 0.260 & -1.158578 & .3130268 \\
\hline
\end{tabular}




\begin{tabular}{|c|c|c|c|c|c|c|}
\hline ind_7 & .0358379 & .454308 & 0.079 & 0.937 & -.8550133 & .9266891 \\
\hline ind_8 & -.401926 & .3766257 & -1.067 & 0.286 & -1.14045 & .3365982 \\
\hline ind_9 & -.7280116 & .3866276 & -1.883 & 0.060 & -1.486149 & .0301253 \\
\hline $\mathrm{msa}$ & .7175332 & .2220337 & 3.232 & 0.001 & .282148 & 1.152918 \\
\hline region2 & -.1699024 & .3349737 & -0.507 & 0.612 & -.8267513 & .4869465 \\
\hline region 3 & .374759 & .2738079 & 1.369 & 0.171 & -.16215 & .911668 \\
\hline region 4 & .2977784 & .3352614 & 0.888 & 0.375 & -.3596347 & .9551914 \\
\hline region 5 & .5607614 & .3140658 & 1.785 & 0.074 & -.0550892 & 1.176612 \\
\hline region 6 & .5778946 & .253987 & 2.275 & 0.023 & .0798523 & 1.075937 \\
\hline region 7 & .3772537 & .2423465 & 1.557 & 0.120 & -.0979628 & .8524702 \\
\hline region 8 & -.0491951 & .2800222 & -0.176 & 0.861 & -.5982897 & .4998994 \\
\hline region 9 & .2621824 & .2741902 & 0.956 & 0.339 & -.2754763 & .7998411 \\
\hline loan2 & -3.388246 & .3605612 & -9.397 & 0.000 & -4.095269 & -2.681223 \\
\hline sources & .114303 & .0475047 & 2.406 & 0.016 & .0211512 & .2074547 \\
\hline edenall & .5794576 & .1869325 & 3.100 & 0.002 & .2129023 & .946013 \\
\hline _cons & 1.194129 & 1.220642 & 0.978 & 0.328 & -1.199424 & 3.587681 \\
\hline
\end{tabular}


EverDen: Firm denied credit anytime over the past three years Model 4

Survey logistic regression

$\begin{array}{ll}\text { pweight: } & \text { new_wgt } \\ \text { Strata: } & \text { newstrat } \\ \text { PSU: } & \text { <observations> }\end{array}$

$\begin{array}{llr}\text { Number of obs } & =r \\ \text { Number of strata } & 1985 \\ \text { Number of PSUs } & = & 65 \\ \text { Population size } & = & 1985 \\ \text { F( 60, 1861) } & = & 3.75 \\ \text { Prob }>\text { F } & = & 0.0000\end{array}$

\begin{tabular}{|c|c|c|c|c|c|c|}
\hline everden & Coef. & Std. Err. & t & $P>|t|$ & [95\% Conf. & Interval] \\
\hline afam & -.3146192 & .6932678 & -0.454 & 0.650 & -1.674256 & 1.045018 \\
\hline hispan & -.0119192 & .6360845 & -0.019 & 0.985 & -1.259408 & 1.23557 \\
\hline asian & 1.576638 & 1.084609 & 1.454 & 0.146 & -.550498 & 3.703775 \\
\hline female & -1.389181 & .4848468 & -2.865 & 0.004 & -2.340063 & -.4382992 \\
\hline hhi & -2.143778 & 1.244714 & -1.722 & 0.085 & -4.58491 & .2973549 \\
\hline afam*hhi & 8.345672 & 4.230668 & 1.973 & 0.049 & .0484855 & 16.64286 \\
\hline hisp*hhi & 1.975196 & 2.922235 & 0.676 & 0.499 & -3.755893 & 7.706284 \\
\hline $\operatorname{asn} \star h h i$ & -5.548594 & 5.583076 & -0.994 & 0.320 & -16.49813 & 5.400937 \\
\hline $\mathrm{fml} * \mathrm{hhi}$ & 6.481088 & 2.114854 & 3.065 & 0.002 & 2.333436 & 10.62874 \\
\hline Inasset & -.189305 & .0715613 & -2.645 & 0.008 & -.329651 & -.048959 \\
\hline lntotemp & -.0186351 & .0942871 & -0.198 & 0.843 & -.2035509 & .1662808 \\
\hline saleasst & .0046813 & .0095218 & 0.492 & 0.623 & -.0139928 & .0233555 \\
\hline liabasst & -.0936714 & .0724501 & -1.293 & 0.196 & -.2357605 & .0484176 \\
\hline profasst & -.018312 & .0299968 & -0.610 & 0.542 & -.0771417 & .0405177 \\
\hline bankrupt & 1.196255 & .4969774 & 2.407 & 0.016 & .2215832 & 2.170928 \\
\hline pdelinq1 & .5985744 & .606649 & 0.987 & 0.324 & -.5911858 & 1.788334 \\
\hline pdelinq2 & .4517929 & .5499868 & 0.821 & 0.411 & -.6268414 & 1.530427 \\
\hline pdelinq3 & 1.046667 & .2904779 & 3.603 & 0.000 & .4769811 & 1.616352 \\
\hline bdel inq1 & .2223973 & .4144858 & 0.537 & 0.592 & -.5904923 & 1.035287 \\
\hline bdelinq2 & .7841021 & .3848726 & 2.037 & 0.042 & .0292899 & 1.538914 \\
\hline bdelinq3 & .3947217 & .2254992 & 1.750 & 0.080 & -.0475275 & .8369709 \\
\hline judgment & .6208068 & .3667512 & 1.693 & 0.091 & -.0984657 & 1.340079 \\
\hline credscr & -.009263 & .0028407 & -3.261 & 0.001 & -.0148341 & -.0036919 \\
\hline prim_fin & -1.125175 & .4917761 & -2.288 & 0.022 & -2.089647 & -.1607041 \\
\hline relprim2 & -.0291519 & .0172074 & -1.694 & 0.090 & -.0628992 & .0045953 \\
\hline ccorp & -.1410809 & .2416778 & -0.584 & 0.559 & -.6150595 & .3328976 \\
\hline scorp & -.1234382 & .2456597 & -0.502 & 0.615 & -.6052261 & .3583497 \\
\hline partner & -.8654036 & .4413173 & -1.961 & 0.050 & -1.730915 & .000108 \\
\hline Inage2 & -.3403329 & .1201482 & -2.833 & 0.005 & -.5759677 & -.1046982 \\
\hline franchis & .5910389 & .4323314 & 1.367 & 0.172 & -.2568497 & 1.438927 \\
\hline d6_natn & .0925224 & .2655314 & 0.348 & 0.728 & -.4282378 & .6132827 \\
\hline d6_outsd & -.6816087 & .7536889 & -0.904 & 0.366 & -2.159744 & .7965261 \\
\hline d6_reg & -.1899332 & .1811238 & -1.049 & 0.294 & -.5451532 & .1652868 \\
\hline checking & -.4685479 & .6020719 & -0.778 & 0.437 & -1.649331 & .7122357 \\
\hline saving & -.2213375 & .1771294 & -1.250 & 0.212 & -.5687237 & .1260488 \\
\hline not_hs & .9342699 & .4502011 & 2.075 & 0.038 & .0513354 & 1.817204 \\
\hline college & -.0040139 & .2191183 & -0.018 & 0.985 & -.4337489 & .425721 \\
\hline exper & .016814 & .0089887 & 1.871 & 0.062 & -.0008145 & .0344426 \\
\hline manage & -.2391525 & .2076135 & -1.152 & 0.250 & -.6463242 & .1680191 \\
\hline ownshr & -.0018842 & .0035762 & -0.527 & 0.598 & -.0088978 & .0051293 \\
\hline tcuse & -.2348881 & .1863363 & -1.261 & 0.208 & -.6003309 & .1305548 \\
\hline ind_1 & .5464176 & .4679903 & 1.168 & 0.243 & -.3714052 & 1.46424 \\
\hline ind_3 & .2897125 & .5277204 & 0.549 & 0.583 & -.7452529 & 1.324678 \\
\hline ind_4 & .3698727 & .5208555 & 0.710 & 0.478 & -.6516293 & 1.391375 \\
\hline ind_5 & .1914087 & .4825261 & 0.397 & 0.692 & -.7549217 & 1.137739 \\
\hline ind_6 6 & .2969666 & .4437586 & 0.669 & 0.503 & -.573333 & 1.167266 \\
\hline
\end{tabular}




\begin{tabular}{|c|c|c|c|c|c|c|}
\hline ind_7 & .2875391 & .5255002 & 0.547 & 0.584 & -.7430721 & 1.31815 \\
\hline ind_8 & .3169155 & .4516166 & 0.702 & 0.483 & -.568795 & 1.202626 \\
\hline ind_9 & -.1921658 & .4715568 & -0.408 & 0.684 & -1.116983 & .7326515 \\
\hline $\mathrm{msa}$ & .5100928 & .2542821 & 2.006 & 0.045 & .0113947 & $\dot{1} .008791$ \\
\hline region2 & -.4991767 & .3918647 & -1.274 & 0.203 & -1.267702 & .2693484 \\
\hline region 3 & .4989364 & .3151094 & 1.583 & 0.114 & -.1190562 & 1.116929 \\
\hline region 4 & .8210317 & .3713988 & 2.211 & 0.027 & .0926443 & 1.549419 \\
\hline region 5 & .7524533 & .3834111 & 1.963 & 0.050 & .0005074 & 1.504399 \\
\hline region 6 & .5516079 & .3130625 & 1.762 & 0.078 & -.0623704 & 1.165586 \\
\hline region 7 & .4690972 & .3007724 & 1.560 & 0.119 & -.1207778 & 1.058972 \\
\hline region 8 & -.0244323 & .3406451 & -0.072 & 0.943 & -.6925055 & .643641 \\
\hline region 9 & .2714836 & .3314859 & 0.819 & 0.413 & -.3786266 & .9215938 \\
\hline loan 4 & .4889536 & .2049285 & 2.386 & 0.017 & .0870477 & .8908595 \\
\hline sources & .0778036 & .0499921 & 1.556 & 0.120 & -.020241 & .1758482 \\
\hline _cons & .5961835 & 1.074171 & 0.555 & 0.579 & -1.510481 & 2.702848 \\
\hline
\end{tabular}


EverDen2: Whether firms expressed credit needs anytime over the past three years

Model 4

Survey logistic regression

$\begin{array}{ll}\text { pweight: } & \text { new_wgt } \\ \text { Strata: } & \text { newstrat } \\ \text { PSU: } & \text { <observations> }\end{array}$

$\begin{array}{llr}\text { Number of obs } & = & 2609 \\ \text { Number of strata } & = & 65 \\ \text { Number of PSUs } & = & 2609 \\ \text { Population size } & = & 2.392 e+08 \\ \text { F( 60, 2485) } & = & 6.71 \\ \text { Prob }>\text { F } & = & 0.0000\end{array}$

\begin{tabular}{|c|c|c|c|c|c|c|}
\hline everden2 & Coef. & Std. Err. & $t$ & $P>|t|$ & [95\% Conf. & Interval] \\
\hline afam & -.0950153 & .6174294 & -0.154 & 0.878 & -1.305731 & 1.1157 \\
\hline hispan & .3474578 & .4761194 & 0.730 & 0.466 & -.5861632 & 1.281079 \\
\hline asian & 1.666616 & .6575189 & 2.535 & 0.011 & .3772896 & 2.955943 \\
\hline female & -1.478615 & .4570512 & -3.235 & 0.001 & -2.374845 & -.582385 \\
\hline hhi & -1.649723 & 1.113725 & -1.481 & 0.139 & -3.833623 & .5341764 \\
\hline afam*hhi & 7.186176 & 3.73587 & 1.924 & 0.055 & -.139479 & 14.51183 \\
\hline hisp*hhi & 1.501007 & 2.407959 & 0.623 & 0.533 & -3.220752 & 6.222766 \\
\hline $\operatorname{asn} * h h i$ & -4.975638 & 3.189824 & -1.560 & 0.119 & -11.23055 & 1.279277 \\
\hline $\mathrm{fml}$ *hhi & 6.846739 & 2.220077 & 3.084 & 0.002 & 2.493397 & 11.20008 \\
\hline Inasset & -.2831692 & .0548267 & -5.165 & 0.000 & -.3906788 & -.1756596 \\
\hline Intotemp & -.0696042 & .0737594 & -0.944 & 0.345 & -.2142387 & .0750304 \\
\hline saleasst & .0069539 & .0062416 & 1.114 & 0.265 & -.0052851 & .019193 \\
\hline liabasst & -.0957086 & .0333672 & -2.868 & 0.004 & -.1611383 & -.0302788 \\
\hline profasst & -.0202146 & .0263005 & -0.769 & 0.442 & -.0717873 & .031358 \\
\hline bankrupt & 1.313492 & .3770521 & 3.484 & 0.001 & .5741315 & 2.052852 \\
\hline pdelinq1 & .6698104 & .5181286 & 1.293 & 0.196 & -.3461863 & 1.685807 \\
\hline pdelinq2 & .4623844 & .5235095 & 0.883 & 0.377 & -.5641638 & 1.488933 \\
\hline pdelinq3 & 1.126346 & .2671951 & 4.215 & 0.000 & .6024035 & 1.650288 \\
\hline bdelinq1 & .2001223 & .3509911 & 0.570 & 0.569 & -.4881351 & .8883796 \\
\hline bdeling2 & .7528339 & .3525038 & 2.136 & 0.033 & .0616104 & 1.444057 \\
\hline bdelinq3 & .4247898 & .198061 & 2.145 & 0.032 & .0364127 & .8131669 \\
\hline judgment & .9047911 & .3002005 & 3.014 & 0.003 & .316129 & 1.493453 \\
\hline credscr & -.0082427 & .0025982 & -3.173 & 0.002 & -.0133374 & -.003148 \\
\hline prim_fin & -.6222266 & .460078 & $-1 \cdot 352$ & 0.176 & -1.524392 & .2799389 \\
\hline relprim2 & -.1818168 & .025228 & -7.207 & 0.000 & -.2312863 & -.1323474 \\
\hline ccorp & .0763917 & .2014935 & 0.379 & 0.705 & -.3187162 & .4714996 \\
\hline scorp & .0061364 & .2052012 & 0.030 & 0.976 & -.3962421 & .4085148 \\
\hline partner & -.6186119 & .3130677 & -1.976 & 0.048 & -1.232505 & -.0047184 \\
\hline Inage2 & .1881377 & .093588 & 2.010 & 0.045 & .0046213 & .371654 \\
\hline franchis & .5618193 & .3794453 & 1.481 & 0.139 & -.1822339 & 1.305872 \\
\hline d6_natn & .1077351 & .2174017 & 0.496 & 0.620 & -.3185672 & .5340374 \\
\hline d6_outsd & .0974585 & .4534883 & 0.215 & 0.830 & -.7917852 & .9867022 \\
\hline$\overline{\mathrm{d}} 6 \_r e g$ & -.2351969 & .1530466 & -1.537 & 0.124 & -.5353055 & .0649117 \\
\hline checking & -.4552862 & .7394383 & -0.616 & 0.538 & -1.905248 & .9946759 \\
\hline saving & -.3233179 & .1590621 & -2.033 & 0.042 & -.6352223 & -.0114135 \\
\hline not_hs & .8488081 & .4348583 & 1.952 & 0.051 & -.0039041 & 1.70152 \\
\hline college & -.06025 & .1784011 & -0.338 & 0.736 & -.4100761 & .2895761 \\
\hline exper & .0183964 & .0080509 & 2.285 & 0.022 & .0026094 & .0341833 \\
\hline manage & -.0556488 & .1881676 & -0.296 & 0.767 & -.424626 & .3133285 \\
\hline ownshr & -.0025595 & .0030436 & -0.841 & 0.400 & -.0085278 & .0034087 \\
\hline tcuse & -.2290429 & .1486099 & -1.541 & 0.123 & -.5204516 & .0623658 \\
\hline ind_1 & .359546 & .3999676 & 0.899 & 0.369 & -.4247491 & 1.143841 \\
\hline ind_3 & -.1684235 & .452329 & -0.372 & 0.710 & -1.055394 & .718547 \\
\hline ind-4 & .5176285 & .4475321 & 1.157 & 0.248 & -.3599359 & 1.395193 \\
\hline ind_5 & .2406664 & .3920916 & 0.614 & 0.539 & -.5281848 & 1.009518 \\
\hline
\end{tabular}




\begin{tabular}{|c|c|c|c|c|c|c|}
\hline ind_6 6 & .2085552 & .3780794 & 0.552 & 0.581 & -.5328194 & .9499298 \\
\hline ind_7 & .1745938 & .4410603 & 0.396 & 0.692 & -.6902798 & 1.039468 \\
\hline ind_8 & .3841554 & .3793288 & 1.013 & 0.311 & -.3596692 & 1.12798 \\
\hline ind_9 & -.2645722 & .3912395 & -0.676 & 0.499 & -1.031752 & .5026081 \\
\hline $\mathrm{msa}$ & .6957813 & .2452843 & 2.837 & 0.005 & .2148041 & 1.176759 \\
\hline region2 & -.2854556 & .3302533 & -0.864 & 0.387 & -.9330483 & .3621371 \\
\hline region 3 & .4817944 & .2656267 & 1.814 & 0.070 & -.039072 & 1.002661 \\
\hline region 4 & .5664193 & .332733 & 1.702 & 0.089 & -.0860358 & 1.218874 \\
\hline region 5 & .7178775 & .3365627 & 2.133 & 0.033 & .0579128 & 1.377842 \\
\hline region 6 & .5020063 & .2452354 & 2.047 & 0.041 & .021125 & .9828877 \\
\hline region 7 & .3454707 & .2403431 & 1.437 & 0.151 & -.1258173 & .8167586 \\
\hline region 8 & -.1354179 & .2945949 & -0.460 & 0.646 & -.713088 & .4422522 \\
\hline region 9 & -.0502363 & .2756542 & -0.182 & 0.855 & -.5907658 & .4902932 \\
\hline loan 4 & .180327 & .1626616 & 1.109 & 0.268 & -.1386357 & .4992897 \\
\hline sources & -.0140793 & .047539 & -0.296 & 0.767 & -.1072983 & .0791397 \\
\hline _cons & .3488017 & .9588392 & 0.364 & 0.716 & -1.531383 & 2.228986 \\
\hline
\end{tabular}


DenMRL: Firm denied for most recent loan application Model 4

Survey logistic regression

$\begin{array}{ll}\text { pweight: } & \text { new_wgt } \\ \text { Strata: } & \text { newstrat } \\ \text { PSU: } & \text { <observations> }\end{array}$

$\begin{array}{llr}\text { Number of obs } & =r \\ \text { Number of strata } & 1985 \\ \text { Number of PSUs } & = & 65 \\ \text { Population size } & = & 1985 \\ \text { F( 69, 1852) } & = & 3.46 \\ \text { Prob > F } & = & 0.0000\end{array}$

\begin{tabular}{|c|c|c|c|c|c|c|}
\hline denmrl & Coef. & Std. Err. & t & $P>|t|$ & [95\% Conf. & Interval] \\
\hline afam & -.1219004 & .6021046 & -0.202 & 0.840 & -1.302748 & 1.058947 \\
\hline hispan & -.1371871 & .681315 & -0.201 & 0.840 & -1.473382 & 1.199008 \\
\hline asian & 3.017853 & 1.199174 & 2.517 & 0.012 & .6660315 & 5.369674 \\
\hline female & -1.240643 & .4858862 & -2.553 & 0.011 & -2.193563 & -.2877225 \\
\hline hhi & -.9525467 & 1.448338 & -0.658 & 0.511 & -3.793027 & 1.887934 \\
\hline afam*hhi & 4.5196 & 3.207525 & 1.409 & 0.159 & -1.770999 & 10.8102 \\
\hline hisp*hhi & .2643577 & 2.967939 & 0.089 & 0.929 & -5.556366 & 6.085081 \\
\hline $\operatorname{asn} \star h h i$ & -14.6457 & 6.476067 & -2.262 & 0.024 & -27.34656 & -1.944832 \\
\hline $\mathrm{fml} * \mathrm{hhi}$ & 6.777387 & 2.005596 & 3.379 & 0.001 & 2.844012 & 10.71076 \\
\hline Inasset & -.2145738 & .0946306 & -2.267 & 0.023 & -.4001632 & -.0289843 \\
\hline Intotemp & -.050854 & .1380573 & -0.368 & 0.713 & -.321612 & .219904 \\
\hline saleasst & .0038636 & .0122528 & 0.315 & 0.753 & -.0201667 & .0278939 \\
\hline liabasst & -.1121298 & .07931 & -1.414 & 0.158 & -.2676725 & .0434129 \\
\hline profasst & -.0555997 & .030994 & -1.794 & 0.073 & -.1163852 & .0051857 \\
\hline bankrupt & 1.566217 & .5359387 & 2.922 & 0.004 & .5151341 & 2.6173 \\
\hline pdeling1 & -.2196239 & .5057288 & -0.434 & 0.664 & -1.211459 & .7722115 \\
\hline pdelinq2 & .4389214 & .449558 & 0.976 & 0.329 & -.4427518 & 1.320595 \\
\hline pdeling3 & .8596831 & .3432916 & 2.504 & 0.012 & .1864195 & 1.532947 \\
\hline bdel inq1 & .9401343 & .5227193 & 1.799 & 0.072 & -.0850228 & 1.965292 \\
\hline bdeling2 & .7362493 & .4359525 & 1.689 & 0.091 & -.1187409 & 1.59124 \\
\hline bdeling3 & .727736 & .2675317 & 2.720 & 0.007 & .2030526 & 1.252419 \\
\hline judgment & .5020597 & .377676 & 1.329 & 0.184 & -.2386386 & 1.242758 \\
\hline credscr & -.0083806 & .0036132 & -2.319 & 0.020 & -.0154667 & -.0012944 \\
\hline fin_jbnk & .9879594 & .4727981 & 2.090 & 0.037 & .0607077 & 1.915211 \\
\hline rel_jbnk & .0009773 & .0176022 & 0.056 & 0.956 & -.0335441 & .0354988 \\
\hline ccorp & -.1222908 & .3024522 & -0.404 & 0.686 & -.7154603 & .4708786 \\
\hline scorp & -.0876665 & .3042896 & -0.288 & 0.773 & -.6844393 & .5091062 \\
\hline partner & -1.017542 & .5560802 & -1.830 & 0.067 & -2.108127 & .0730424 \\
\hline Inage2 & -.4722045 & .139645 & -3.381 & 0.001 & -.7460764 & -.1983327 \\
\hline franchis & 1.253185 & .4586491 & 2.732 & 0.006 & .3536825 & 2.152688 \\
\hline d6_natn & .3665204 & .3222839 & 1.137 & 0.256 & -.265543 & .9985837 \\
\hline d6_outsd & -.0858181 & .9110794 & -0.094 & 0.925 & -1.872627 & 1.700991 \\
\hline d6_reg & .0080242 & .2195339 & 0.037 & 0.971 & -.4225257 & .4385741 \\
\hline checking & -1.353957 & .6568556 & -2.061 & 0.039 & -2.642182 & -.0657318 \\
\hline saving & -.4069935 & .2255334 & -1.805 & 0.071 & -.8493096 & .0353227 \\
\hline not_hs & .7955468 & .6081443 & 1.308 & 0.191 & -.3971461 & 1.98824 \\
\hline college & .0136841 & .2541173 & 0.054 & 0.957 & -.4846909 & .5120591 \\
\hline exper & .0101591 & .0114793 & 0.885 & 0.376 & -.0123541 & .0326723 \\
\hline manage & -.5209372 & .25504 & -2.043 & 0.041 & -1.021122 & -.0207527 \\
\hline ownshr & -.0040735 & .0046495 & -0.876 & 0.381 & -.0131922 & .0050451 \\
\hline tcuse & -.5534379 & .2271503 & -2.436 & 0.015 & -.9989252 & -.1079506 \\
\hline ind_1 & .3189728 & .5967099 & 0.535 & 0.593 & -.8512947 & 1.48924 \\
\hline ind_3 & .2657084 & .699294 & 0.380 & 0.704 & -1.105747 & 1.637164 \\
\hline ind_4 & .259972 & .6610977 & 0.393 & 0.694 & -1.036573 & 1.556517 \\
\hline ind_5 & .3513362 & .6002206 & 0.585 & 0.558 & -.8258166 & 1.528489 \\
\hline ind_6 & .3952232 & .5626849 & 0.702 & 0.483 & -.7083146 & 1.498761 \\
\hline
\end{tabular}




\begin{tabular}{|c|c|c|c|c|c|c|}
\hline ind_7 & -.3866415 & .6864648 & -0.563 & 0.573 & -1.732936 & .9596535 \\
\hline ind_8 & .1309859 & .5708241 & 0.229 & 0.819 & -.9885145 & 1.250486 \\
\hline ind_9 & -.3660153 & .6148469 & -0.595 & 0.552 & -1.571853 & .8398226 \\
\hline $\mathrm{msa}$ & .7409081 & .3349395 & 2.212 & 0.027 & .0840246 & 1.397792 \\
\hline region2 & -.7115811 & .5368343 & -1.326 & 0.185 & -1.764421 & .3412585 \\
\hline region 3 & .6090493 & .3793167 & 1.606 & 0.109 & -.1348667 & 1.352965 \\
\hline region 4 & .9787503 & .4593923 & 2.131 & 0.033 & .0777901 & 1.879711 \\
\hline region 5 & .5597462 & .4895452 & 1.143 & 0.253 & -.40035 & 1.519842 \\
\hline region 6 & .7523908 & .3757695 & 2.002 & 0.045 & .0154316 & 1.48935 \\
\hline region 7 & .84173 & .3769745 & 2.233 & 0.026 & .1024075 & 1.581053 \\
\hline region 8 & .115045 & .4553621 & 0.253 & 0.801 & -.7780113 & 1.008101 \\
\hline region 9 & .0604895 & .3944588 & 0.153 & 0.878 & -.7131233 & .8341023 \\
\hline loan 4 & 1.19942 & .2723704 & 4.404 & 0.000 & .6652474 & 1.733593 \\
\hline j5_asst & .1020683 & .0349473 & 2.921 & 0.004 & .0335297 & .170607 \\
\hline mrl_loc & -.2436519 & .3349521 & -0.727 & 0.467 & -.9005601 & .413256 \\
\hline mrl_mv & -1.127251 & .4971096 & -2.268 & 0.023 & -2.102183 & -.152319 \\
\hline mrl_oth & .577051 & .3538774 & 1.631 & 0.103 & -.1169735 & 1.271075 \\
\hline mrl_teas & -.2531498 & .6378409 & -0.397 & 0.691 & -1.504084 & .997784 \\
\hline mrl_mrtg & -.2615629 & .4433307 & -0.590 & 0.555 & -1.131023 & .607897 \\
\hline use_mrl & .227217 & .2308115 & 0.984 & 0.325 & -.2254505 & .679884 \\
\hline lend_src & -.4079752 & .1416348 & -2.880 & 0.004 & -.6857494 & -.130201 \\
\hline mrl_prim & -.5028819 & .2172298 & -2.315 & 0.021 & -.928913 & -.076850 \\
\hline mrl_9394 & -.7655829 & .2516407 & -3.042 & 0.002 & -1.259101 & -.272065 \\
\hline _cons & .1408846 & 1.359658 & 0.104 & 0.917 & -2.525676 & 2.8074 \\
\hline
\end{tabular}


IntRate: Interest rate on most recent loan Model 4

Survey linear regression

$\begin{array}{ll}\text { pweight: } & \text { new_wgt } \\ \text { Strata: } & \text { newstrat } \\ \text { PSU: } & \text { <observations> }\end{array}$

$\begin{array}{llr}\text { Number of obs } & = & 1682 \\ \text { Number of strata } & = & 65 \\ \text { Number of PSUs } & = & 1682 \\ \text { Population size } & = & 1.378 e+08 \\ \text { F(79, 1539) } & = & 3.60 \\ \text { Prob > F } & = & 0.0000 \\ \text { R-squared } & = & 0.2587\end{array}$

\begin{tabular}{|c|c|c|c|c|c|c|}
\hline intrate & Coef. & Std. Err. & t & $P>|t|$ & [95\% Conf. & Interval] \\
\hline afam & 1.965187 & 1.221429 & 1.609 & 0.108 & -.4305625 & 4.360936 \\
\hline hispan & -1.1771 & .7902371 & -1.490 & 0.137 & -2.727096 & .3728964 \\
\hline asian & -.1209118 & .6397868 & -0.189 & 0.850 & -1.37581 & 1.133986 \\
\hline female & .8536133 & .4403557 & 1.938 & 0.053 & -.0101145 & 1.717341 \\
\hline hhi & 1.739021 & .8948311 & 1.943 & 0.052 & -.0161293 & 3.494172 \\
\hline $\operatorname{afam} * \mathrm{hhi}$ & -10.71536 & 5.952226 & -1.800 & 0.072 & -22.39024 & .9595287 \\
\hline hisp*hhi & 6.28796 & 4.498685 & 1.398 & 0.162 & -2.535905 & 15.11183 \\
\hline $\operatorname{asn} * h h i$ & 1.586062 & 3.242807 & 0.489 & 0.625 & -4.774484 & 7.946607 \\
\hline $\mathrm{fml} \star \mathrm{hhi}$ & -5.504027 & 1.933482 & -2.847 & 0.004 & -9.296421 & -1.711632 \\
\hline Inasset & .0545042 & .0916844 & 0.594 & 0.552 & -.1253285 & .2343368 \\
\hline Intotemp & -.1097438 & .0822553 & -1.334 & 0.182 & -.271082 & .0515944 \\
\hline saleasst & .0029083 & .0095439 & 0.305 & 0.761 & -.0158115 & .0216281 \\
\hline liabasst & .229378 & .0920049 & 2.493 & 0.013 & .0489166 & .4098395 \\
\hline profasst & -.0054794 & .022603 & -0.242 & 0.808 & -.0498137 & .0388549 \\
\hline bankrupt & .4407684 & .5191697 & 0.849 & 0.396 & -.5775477 & 1.459084 \\
\hline pdelinq1 & -1.642902 & .7170258 & -2.291 & 0.022 & -3.049299 & -.2365043 \\
\hline pdeling2 & .346727 & .4364106 & 0.794 & 0.427 & -.5092627 & 1.202717 \\
\hline pdelinq3 & -.2154166 & .3547189 & -0.607 & 0.544 & -.9111737 & .4803404 \\
\hline bdelingl & .1328155 & .5855173 & 0.227 & 0.821 & -1.015637 & 1.281268 \\
\hline bdelinq2 & -.6383573 & .3596754 & -1.775 & 0.076 & -1.343836 & .0671216 \\
\hline bdeling3 & -.0564221 & .2288497 & -0.247 & 0.805 & -.5052953 & .3924511 \\
\hline judgment & .4789663 & .8350824 & 0.574 & 0.566 & -1.158991 & 2.116924 \\
\hline credscr & -.0096765 & .0025959 & -3.728 & 0.000 & -.0147682 & -.0045847 \\
\hline fin_jbnk & 1.611566 & .7218182 & 2.233 & 0.026 & .1957682 & 3.027363 \\
\hline rel_jbnk & .0068947 & .0103793 & 0.664 & 0.507 & -.0134637 & .027253 \\
\hline ccorp & -.1935731 & .238917 & -0.810 & 0.418 & -.6621926 & .2750464 \\
\hline scorp & -.3186858 & .2376431 & -1.341 & 0.180 & -.7848066 & .147435 \\
\hline partner & .0021701 & .3427628 & 0.006 & 0.995 & -.6701358 & .674476 \\
\hline lnage 2 & -.0342034 & .0986036 & -0.347 & 0.729 & -.2276076 & .1592009 \\
\hline franchis & .072631 & .2606944 & 0.279 & 0.781 & -.4387033 & .5839653 \\
\hline d6_natn & .0366255 & .2100213 & 0.174 & 0.862 & -.3753171 & .448568 \\
\hline d6_outsd & .7135379 & .3708593 & 1.924 & 0.055 & -.0138775 & 1.440953 \\
\hline d6_reg & .2394296 & .178321 & 1.343 & 0.180 & -.110335 & .5891942 \\
\hline checking & -1.347802 & .6774614 & -1.989 & 0.047 & -2.676596 & -.0190073 \\
\hline saving & -.0432293 & .1537486 & -0.281 & 0.779 & -.3447967 & .258338 \\
\hline not_hs & .5739139 & 1.143105 & 0.502 & 0.616 & -1.668209 & 2.816037 \\
\hline college & -.1849878 & .1923747 & -0.962 & 0.336 & -.5623176 & .1923421 \\
\hline exper & -.0097392 & .0075462 & -1.291 & 0.197 & -.0245405 & .0050621 \\
\hline manage & -.1165896 & .2088233 & -0.558 & 0.577 & -.5261824 & .2930031 \\
\hline ownshr & .0018198 & .0027106 & 0.671 & 0.502 & -.0034968 & .0071364 \\
\hline tcuse & -.1114754 & .1961322 & -0.568 & 0.570 & -.4961754 & .2732247 \\
\hline ind_1 & -.4386528 & .610568 & -0.718 & 0.473 & -1.63624 & .7589348 \\
\hline ind_3 & -.8067279 & .5398658 & -1.494 & 0.135 & -1.865638 & .2521822 \\
\hline ind_-4 & .0600128 & .6837102 & 0.088 & 0.930 & -1.281038 & 1.401064 \\
\hline ind_5 & -.9638946 & .6507715 & -1.481 & 0.139 & -2.240339 & .3125494 \\
\hline ind_6 6 & -.5506744 & .5820286 & -0.946 & 0.344 & -1.692284 & .5909352 \\
\hline ind_7 & -.9348553 & .6548937 & -1.427 & 0.154 & -2.219385 & .3496743 \\
\hline
\end{tabular}




\begin{tabular}{|c|c|c|c|c|c|c|}
\hline ind_8 & -.5765067 & .5916162 & -0.974 & 0.330 & -1.736922 & .5839084 \\
\hline ind_e 9 & -.6228811 & .5768509 & -1.080 & 0.280 & -1.754335 & .5085728 \\
\hline $\mathrm{msa}$ & .1120929 & .1949558 & 0.575 & 0.565 & -.2702996 & .4944854 \\
\hline region2 & -.0538695 & .2999968 & -0.180 & 0.858 & -.6422929 & .5345538 \\
\hline region 3 & -.1674271 & .3014785 & -0.555 & 0.579 & -.7587568 & .4239026 \\
\hline region 4 & -.3490097 & .3051099 & -1.144 & 0.253 & -.9474621 & .2494427 \\
\hline region 5 & .3709809 & .3843284 & 0.965 & 0.335 & -.3828532 & 1.124815 \\
\hline region 6 & .7861103 & .3277695 & 2.398 & 0.017 & .1432127 & 1.429008 \\
\hline region 7 & .0568088 & .2586393 & 0.220 & 0.826 & -.4504946 & .5641122 \\
\hline region 8 & .1011155 & .2618709 & 0.386 & 0.699 & -.4125264 & .6147574 \\
\hline region 9 & -.0348252 & .2460431 & -0.142 & 0.887 & -.517422 & .4477717 \\
\hline bondsprd & .2432411 & .3738255 & 0.651 & 0.515 & -.4899923 & .9764744 \\
\hline termprem & -.1949671 & .1437865 & -1.356 & 0.175 & -.4769944 & .0870603 \\
\hline mrl_indx & .6312593 & .1419134 & 4.448 & 0.000 & .3529059 & .9096128 \\
\hline $\bar{f}$ ixed & .5174601 & .2538401 & 2.039 & 0.042 & .01957 & 1.01535 \\
\hline pcol & -.0700024 & .1604657 & -0.436 & 0.663 & -.3847449 & .2447402 \\
\hline $\mathrm{bcol}$ & .1429574 & .1445824 & 0.989 & 0.323 & -.1406311 & .4265459 \\
\hline guar & -.0815881 & .1707471 & -0.478 & 0.633 & -.416497 & .2533207 \\
\hline mrl_loc & -.0721576 & .3184487 & -0.227 & 0.821 & -.6967731 & .5524579 \\
\hline mrl_leas & .4613541 & .5687721 & 0.811 & 0.417 & -.6542536 & 1.576962 \\
\hline mrl_mrtg & .2548781 & .3458926 & 0.737 & 0.461 & -.4235669 & .933323 \\
\hline mrl_mv & -.6821979 & .3761729 & -1.814 & 0.070 & -1.420036 & .0556398 \\
\hline mrl_oth & .9582798 & .4187784 & 2.288 & 0.022 & .1368745 & 1.779685 \\
\hline lend_src & .086702 & .076378 & 1.135 & 0.256 & -.0631083 & .2365123 \\
\hline loan 4 & .0828621 & .1820873 & 0.455 & 0.649 & -.2742898 & .4400139 \\
\hline mrl_9394 & -.0147437 & .2072976 & -0.071 & 0.943 & -.4213438 & .3918564 \\
\hline mrl_prim & -.3711326 & .212113 & -1.750 & 0.080 & -.7871779 & .0449126 \\
\hline edenall & .5886543 & .2838718 & 2.074 & 0.038 & .031859 & 1.14545 \\
\hline invmat & -.7543634 & .6287386 & -1.200 & 0.230 & -1.987592 & .4788647 \\
\hline lnamtbrr & -.3078303 & .0876563 & -3.512 & 0.000 & -.4797623 & -.1358984 \\
\hline points & -.0588935 & .0889554 & -0.662 & 0.508 & -.2333734 & .1155863 \\
\hline fee_amt & .9863132 & 1.478274 & 0.667 & 0.505 & -1.91322 & 3.88584 \\
\hline _cons & 8.36461 & 2.202552 & 3.798 & 0.000 & 4.044453 & 12.6847 \\
\hline
\end{tabular}




\title{
Estimated Coefficients for Line of Credit Analysis
}

\author{
HaveLOC: Firm has a line of credit \\ Model 4
}

Survey logistic regression

$\begin{array}{ll}\text { pweight: } & \text { new_wgt } \\ \text { Strata: } & \text { newstrat } \\ \text { PSU: } & \text { <observations> }\end{array}$

$\begin{array}{llr}\text { Number of obs } & = & 4570 \\ \text { Number of strata } & = & 65 \\ \text { Number of PSUs } & = & 4570 \\ \text { Population size } & = & 4.898 e+08 \\ \text { F( 61, 4445) } & = & 9.09 \\ \text { Prob }>\text { F } & = & 0.0000\end{array}$

\begin{tabular}{|c|c|c|c|c|c|c|}
\hline haveloc & Coef. & Std. Err. & t & $P>|t|$ & [95\% Conf. & Interval] \\
\hline afam & -.1657937 & .2995411 & -0.553 & 0.580 & -.7530412 & .4214537 \\
\hline hispan & .9329805 & .4311089 & 2.164 & 0.031 & .0877956 & 1.778166 \\
\hline asian & -.2138098 & .3876909 & -0.551 & 0.581 & -.9738743 & .5462546 \\
\hline female & .4003241 & .2745959 & 1.458 & 0.145 & -.1380185 & .9386667 \\
\hline hhi & .8116375 & .5873009 & 1.382 & 0.167 & -.3397604 & 1.963035 \\
\hline afam*hhi & .8757198 & 1.468067 & 0.597 & 0.551 & -2.002412 & 3.753852 \\
\hline hisp*hhi & -2.956606 & 2.108317 & -1.402 & 0.161 & -7.089942 & 1.176731 \\
\hline $\operatorname{asn} \star h h i$ & -2.449537 & 1.77397 & -1.381 & 0.167 & -5.927388 & 1.028313 \\
\hline $\mathrm{fml} * \mathrm{hhi}$ & -2.47597 & 1.166086 & -2.123 & 0.034 & -4.76207 & -.1898695 \\
\hline lnasset & .3323905 & .0427038 & 7.784 & 0.000 & .2486701 & .416111 \\
\hline lntotemp & .1943599 & .0544103 & 3.572 & 0.000 & .087689 & .3010307 \\
\hline saleasst & .0065027 & .0049871 & 1.304 & 0.192 & -.0032744 & .0162798 \\
\hline liabasst & .1523841 & .0702381 & 2.170 & 0.030 & .0146829 & .2900853 \\
\hline profasst & -.0111386 & .0200984 & -0.554 & 0.579 & -.0505414 & .0282643 \\
\hline bankrupt & -.5346259 & .3634832 & -1.471 & 0.141 & -1.247231 & .1779794 \\
\hline pdelingl & -.6906822 & .3636415 & -1.899 & 0.058 & -1.403598 & .0222336 \\
\hline pdelinq2 & -.1189769 & .3251791 & -0.366 & 0.714 & -.7564874 & .5185336 \\
\hline pdeling3 & -.4312232 & .2151657 & -2.004 & 0.045 & -.8530536 & -.0093928 \\
\hline bdelinq1 & -.0619224 & .277495 & -0.223 & 0.823 & -.6059486 & .4821039 \\
\hline bdeling2 & -.0946755 & .2629964 & -0.360 & 0.719 & -.6102776 & .4209265 \\
\hline bdeling3 & .3199439 & .1746199 & 1.832 & 0.067 & -.0223966 & .6622845 \\
\hline judgment & -.16585 & .2431246 & -0.682 & 0.495 & -.6424935 & .3107935 \\
\hline credscr & .0016532 & .0017949 & 0.921 & 0.357 & -.0018656 & .0051721 \\
\hline prim_fin & .2756322 & .3260816 & 0.845 & 0.398 & -.3636477 & .9149121 \\
\hline rel_prim & -.0139825 & .0069474 & -2.013 & 0.044 & -.0276028 & -.0003622 \\
\hline $\mathrm{ccorp}$ & .0316321 & .1464173 & 0.216 & 0.829 & -.2554176 & .3186818 \\
\hline scorp & -.0612551 & .1568936 & -0.390 & 0.696 & -.3688435 & .2463334 \\
\hline partner & -.2404166 & .2241806 & -1.072 & 0.284 & -.6799206 & .1990875 \\
\hline lnage & -.0196393 & .0832528 & -0.236 & 0.814 & -.1828556 & .143577 \\
\hline franchis & -.3839942 & .2898196 & -1.325 & 0.185 & -.9521828 & .1841943 \\
\hline d6_natn & .3696878 & .1652119 & 2.238 & 0.025 & .0457914 & .6935842 \\
\hline d6_outsd & .052367 & .3688438 & 0.142 & 0.887 & -.6707479 & .7754818 \\
\hline d6_reg & .4536512 & .1086901 & 4.174 & 0.000 & .2405653 & .6667371 \\
\hline checking & 1.289831 & .5776127 & 2.233 & 0.026 & .1574268 & 2.422235 \\
\hline saving & -.0539082 & .1111984 & -0.485 & 0.628 & -.2719116 & .1640952 \\
\hline not_hs & -.419602 & .2617832 & -1.603 & 0.109 & -.9328256 & .0936216 \\
\hline college & .0664889 & .1208151 & 0.550 & 0.582 & -.170368 & .3033458 \\
\hline exper & -.0129729 & .0051896 & -2.500 & 0.012 & -.0231471 & -.0027986 \\
\hline manage & -.0285285 & .1275574 & -0.224 & 0.823 & -.2786035 & .2215466 \\
\hline ownshr & .0018936 & .0022038 & 0.859 & 0.390 & -.0024269 & .0062142 \\
\hline tcuse & .2944086 & .1083353 & 2.718 & 0.007 & .0820183 & .5067989 \\
\hline ind_1 & .1191704 & .2531151 & 0.471 & 0.638 & -.3770595 & .6154003 \\
\hline ind_3 & -.1200202 & .2940572 & -0.408 & 0.683 & -.6965166 & .4564763 \\
\hline
\end{tabular}




\begin{tabular}{|c|c|c|c|c|c|c|}
\hline ind_4 & -.4953797 & .3414271 & -1.451 & 0.147 & -1.164744 & .1739849 \\
\hline ind_5 & .2911938 & .2583156 & 1.127 & 0.260 & -.2152316 & .7976191 \\
\hline ind_6 & .0041607 & .2432083 & 0.017 & 0.986 & -.4726468 & .4809682 \\
\hline ind_7 & -.6263324 & .3043254 & -2.058 & 0.040 & -1.222959 & -.0297054 \\
\hline ind_8 & -.328419 & .2521057 & -1.303 & 0.193 & -.82267 & .1658319 \\
\hline ind_9 & .0454959 & .2509825 & 0.181 & 0.856 & -.4465529 & .5375448 \\
\hline $\mathrm{msa}$ & -.3339829 & .1442487 & -2.315 & 0.021 & -.6167812 & -.0511846 \\
\hline region2 & .3047788 & .2360886 & 1.291 & 0.197 & -.1580708 & .7676284 \\
\hline region 3 & -.1244739 & .1853198 & -0.672 & 0.502 & -.4877918 & .2388439 \\
\hline region 4 & .2737534 & .2274743 & 1.203 & 0.229 & -.1722079 & .7197147 \\
\hline region 5 & -.0137734 & .2153596 & -0.064 & 0.949 & -.4359838 & .4084371 \\
\hline region 6 & .1037156 & .1694858 & 0.612 & 0.541 & -.2285597 & .435991 \\
\hline region 7 & .1094074 & .1688053 & 0.648 & 0.517 & -.2215338 & .4403486 \\
\hline region 8 & .6106629 & .1932666 & 3.160 & 0.002 & .2317655 & .9895603 \\
\hline region 9 & .3140703 & .1951177 & 1.610 & 0.108 & -.0684561 & .6965966 \\
\hline sources & .2071534 & .0362327 & 5.717 & 0.000 & .1361195 & .2781873 \\
\hline edenall & .2120359 & .1667033 & 1.272 & 0.203 & -.1147843 & .538856 \\
\hline fearden 2 & -.369996 & .1402033 & -2.639 & 0.008 & -.6448632 & -.0951289 \\
\hline _cons & -2.7055 & .7037607 & -3.844 & 0.000 & -4.085217 & -1.325784 \\
\hline
\end{tabular}


ApplyLOC: Firm applied for a line of credit within the past three years Model 3

Survey logistic regression

pweight: new_wgt

Strata: newstrat

PSU : $\quad$ <observations>

$\begin{array}{llr}\text { Number of obs } & = & 4570 \\ \text { Number of strata } & 65 \\ \text { Number of PSUs } & = & 4570 \\ \text { Population size } & = & 4.898 e+08 \\ \text { F(55, 4451) } & = & 8.60 \\ \text { Prob }>\text { F } & = & 0.0000\end{array}$

\begin{tabular}{|c|c|c|c|c|c|c|}
\hline applyloc & Coef. & Std. Err. & $t$ & $P>|t|$ & [95\% Conf. & Interval] \\
\hline afam & .0174866 & .1793758 & 0.097 & 0.922 & -.3341779 & .3691511 \\
\hline hispan & -.0718439 & .2384791 & -0.301 & 0.763 & -.53938 & .3956922 \\
\hline asian & -.5264758 & .2276274 & -2.313 & 0.021 & -.9727372 & -.0802144 \\
\hline female & -.1104649 & .144737 & -0.763 & 0.445 & -.3942204 & .1732907 \\
\hline hhi & -.0537694 & .5696732 & -0.094 & 0.925 & -1.170608 & 1.06307 \\
\hline Inasset & .319439 & .0449241 & 7.111 & 0.000 & .2313657 & .4075124 \\
\hline Intotemp & .1436296 & .0590497 & 2.432 & 0.015 & .0278633 & .2593959 \\
\hline saleasst & .0089945 & .0049546 & 1.815 & 0.070 & -.000719 & .0187081 \\
\hline liabasst & .2042971 & .0740381 & 2.759 & 0.006 & .0591461 & .3494481 \\
\hline profasst & -.001299 & .010822 & -0.120 & 0.904 & -.0225154 & .0199174 \\
\hline bankrupt & -.156983 & .3800853 & -0.413 & 0.680 & -.9021366 & .5881706 \\
\hline pdelinq1 & -.7777756 & .4060641 & -1.915 & 0.056 & -1.57386 & .0183093 \\
\hline pdelinq2 & -.4558454 & .367689 & -1.240 & 0.215 & -1.176696 & .2650055 \\
\hline pdeling3 & .1822651 & .2193775 & 0.831 & 0.406 & -.2478224 & .6123526 \\
\hline bdelinq1 & .0495153 & .2867692 & 0.173 & 0.863 & -.512693 & .6117237 \\
\hline bdeling2 & .1527077 & .2670996 & 0.572 & 0.568 & -.3709385 & .6763538 \\
\hline bdeling3 & .0374587 & .1833517 & 0.204 & 0.838 & -.3220006 & .3969179 \\
\hline judgment & -.4781599 & .2813671 & -1.699 & 0.089 & -1.029777 & .0734577 \\
\hline credscr & .0000527 & .0020164 & 0.026 & 0.979 & -.0039005 & .0040059 \\
\hline prim_fin & .1900029 & .3350254 & 0.567 & 0.571 & -.4668113 & .8468171 \\
\hline rel_prim & -.0136504 & .0084546 & -1.615 & 0.106 & -.0302254 & .0029247 \\
\hline ccorp & .2694689 & .1656426 & 1.627 & 0.104 & -.0552719 & .5942098 \\
\hline scorp & .1016938 & .1759285 & 0.578 & 0.563 & -.2432123 & .4465999 \\
\hline partner & -.1146086 & .2555696 & -0.448 & 0.654 & -.6156505 & .3864332 \\
\hline Inage & .0865681 & .0928506 & 0.932 & 0.351 & -.0954647 & .268601 \\
\hline franchis & -.3728059 & .3384191 & -1.102 & 0.271 & -1.036273 & .2906616 \\
\hline d6_natn & .8114255 & .1719172 & 4.720 & 0.000 & .4743835 & 1.148468 \\
\hline d6_outsd & -.1400369 & .3677601 & -0.381 & 0.703 & -.8610271 & .5809532 \\
\hline d6_reg & .500986 & .1205225 & 4.157 & 0.000 & .2647028 & .7372691 \\
\hline checking & .4535472 & .5062865 & 0.896 & 0.370 & -.5390228 & 1.446117 \\
\hline saving & -.0095869 & .1222364 & -0.078 & 0.937 & -.2492303 & .2300565 \\
\hline not_hs & -.3772527 & .3692846 & -1.022 & 0.307 & -1.101232 & .3467263 \\
\hline college & .1236929 & .1381455 & 0.895 & 0.371 & -.14714 & .3945257 \\
\hline exper & -.0242754 & .0059917 & -4.051 & 0.000 & -.0360221 & -.0125287 \\
\hline manage & .0006498 & .1358579 & 0.005 & 0.996 & -.2656984 & .2669979 \\
\hline ownshr & .0011242 & .0022944 & 0.490 & 0.624 & -.003374 & .0056224 \\
\hline tcuse & .3251594 & .122771 & 2.649 & 0.008 & .084468 & .5658508 \\
\hline ind_1 & .0323999 & .2653953 & 0.122 & 0.903 & -.4879051 & .5527049 \\
\hline ind_3 & -.075767 & .3032703 & -0.250 & 0.803 & -.6703256 & .5187917 \\
\hline ind_4 & -.2946383 & .3562571 & -0.827 & 0.408 & -.993077 & .4038005 \\
\hline ind_5 & .3953228 & .2649619 & 1.492 & 0.136 & -.1241325 & .914778 \\
\hline ind_6 & .1592373 & .2512395 & 0.634 & 0.526 & -.3333154 & .65179 \\
\hline ind_-7 & -.435652 & .326052 & -1.336 & 0.182 & -1.074874 & .2035699 \\
\hline ind_8 & -.1440837 & .2611776 & -0.552 & 0.581 & -.65612 & .3679526 \\
\hline ind_e 9 & .2186486 & .2584567 & 0.846 & 0.398 & -.2880533 & .7253504 \\
\hline $\mathrm{msa}$ & -.3079686 & .1562655 & -1.971 & 0.049 & -.6143255 & -.0016116 \\
\hline
\end{tabular}




\begin{tabular}{|c|c|c|c|c|c|c|}
\hline region2 & .202593 & .2552318 & 0.794 & 0.427 & -.2977865 & .7029725 \\
\hline region 3 & -.1560803 & .197908 & -0.789 & 0.430 & -.5440771 & .2319165 \\
\hline region 4 & .0577387 & .2581235 & 0.224 & 0.823 & -.44831 & .5637874 \\
\hline region 5 & -.3592622 & .2546866 & -1.411 & 0.158 & -.8585729 & .1400485 \\
\hline region 6 & -.237225 & .1852476 & -1.281 & 0.200 & -.6004012 & .1259513 \\
\hline region 7 & -.149878 & .1819647 & -0.824 & 0.410 & -.5066181 & .2068621 \\
\hline region 8 & .2050528 & .2109798 & 0.972 & 0.331 & -.2085711 & .6186768 \\
\hline region 9 & .230033 & .2103045 & 1.094 & 0.274 & -.182267 & .642333 \\
\hline sources & .1300756 & .0359837 & 3.615 & 0.000 & .0595299 & .2006213 \\
\hline _cons & -2.250442 & .7474527 & -3.011 & 0.003 & -3.715817 & -.7850685 \\
\hline
\end{tabular}


DenLOC: Firm denied for most recent line of credit application Model 4

Survey logistic regression

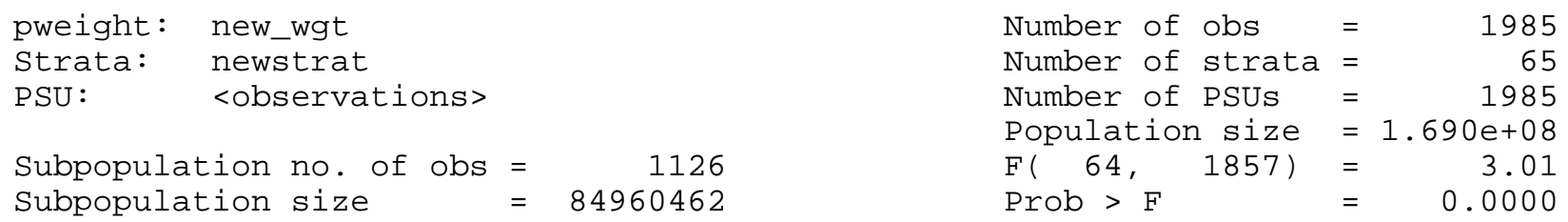

\begin{tabular}{|c|c|c|c|c|c|c|}
\hline denmrl & Coef. & Std. Err. & $t$ & $P>|t|$ & [95\% Conf. & Interval] \\
\hline afam & -2.038159 & 1.227675 & -1.660 & 0.097 & -4.445876 & .3695586 \\
\hline hispan & -.2397445 & 1.240953 & -0.193 & 0.847 & -2.673503 & 2.194014 \\
\hline asian & 3.40153 & 2.754008 & 1.235 & 0.217 & -1.999632 & 8.802692 \\
\hline female & -1.647549 & .9397444 & -1.753 & 0.080 & -3.490576 & .1954782 \\
\hline hhi & -2.227937 & 2.17806 & -1.023 & 0.306 & -6.499549 & 2.043676 \\
\hline afam*hhi & 17.41808 & 6.760742 & 2.576 & 0.010 & 4.158915 & 30.67725 \\
\hline hisp*hhi & -2.86094 & 6.903151 & -0.414 & 0.679 & -16.3994 & 10.67752 \\
\hline $\operatorname{asn} * h h i$ & -17.70938 & 15.98663 & -1.108 & 0.268 & -49.06235 & 13.6436 \\
\hline $\mathrm{fml} * \mathrm{hhi}$ & 6.760142 & 4.080287 & 1.657 & 0.098 & -1.242117 & 14.7624 \\
\hline Inasset & -.4953449 & .188166 & -2.632 & 0.009 & -.864376 & -.1263138 \\
\hline Intotemp & .0901167 & .2376006 & 0.379 & 0.705 & -.3758657 & .5560991 \\
\hline saleasst & .0037953 & .0144758 & 0.262 & 0.793 & -.0245947 & .0321853 \\
\hline liabasst & -.0568826 & .1254353 & -0.453 & 0.650 & -.3028863 & .1891211 \\
\hline profasst & -.0317495 & .0509276 & -0.623 & 0.533 & -.1316287 & .0681296 \\
\hline bankrupt & 1.421161 & 1.297188 & 1.096 & 0.273 & -1.122885 & 3.965206 \\
\hline pdelinq1 & 1.364864 & .8049785 & 1.696 & 0.090 & -.2138596 & 2.943588 \\
\hline pdelinq2 & -.1052338 & .7149554 & -0.147 & 0.883 & -1.507404 & 1.296937 \\
\hline pdelinq3 & .9678693 & .5393092 & 1.795 & 0.073 & -.0898239 & 2.025563 \\
\hline bdelinq1 & 1.563188 & .8676887 & 1.802 & 0.072 & -.138523 & 3.2649 \\
\hline bdelinq2 & 1.405856 & .5243426 & 2.681 & 0.007 & .3775147 & 2.434197 \\
\hline bdeling3 & .6183585 & .437131 & 1.415 & 0.157 & -.238943 & 1.47566 \\
\hline judgment & -.5400308 & .5824127 & -0.927 & 0.354 & -1.682259 & .6021972 \\
\hline credscr & -.0119555 & .0059174 & -2.020 & 0.043 & -.0235608 & -.0003502 \\
\hline fin_jbnk & 4.309286 & .971297 & 4.437 & 0.000 & 2.404378 & 6.214194 \\
\hline rel_jbnk & -.0342945 & .0347147 & -0.988 & 0.323 & -.102377 & .033788 \\
\hline ccorp & -.4937811 & .4528595 & -1.090 & 0.276 & -1.381929 & .3943671 \\
\hline scorp & .2241021 & .5147429 & 0.435 & 0.663 & -.7854119 & 1.233616 \\
\hline partner & -1.473948 & 1.096869 & $-1 \cdot 344$ & 0.179 & -3.625128 & .6772321 \\
\hline Inage2 & -.4121524 & .2283919 & -1.805 & 0.071 & -.8600746 & .0357699 \\
\hline franchis & 1.222556 & .7038222 & 1.737 & 0.083 & -.1577804 & 2.602892 \\
\hline d6_natn & .0356342 & .4472692 & 0.080 & 0.937 & -.8415502 & .9128186 \\
\hline d6_outsd & -1.379139 & .9881705 & -1.396 & 0.163 & -3.317139 & .5588613 \\
\hline d6_reg & -.5291335 & .3826942 & -1.383 & 0.167 & -1.279673 & .2214064 \\
\hline checking & -5.103903 & 1.311141 & -3.893 & 0.000 & -7.675313 & -2.532493 \\
\hline saving & -.5208617 & .4138354 & -1.259 & 0.208 & -1.332476 & .2907524 \\
\hline not_hs & 1.361571 & 1.10739 & 1.230 & 0.219 & -.8102417 & 3.533385 \\
\hline college & .0126631 & .5135404 & 0.025 & 0.980 & -.9944924 & 1.019819 \\
\hline exper & .0160317 & .019087 & 0.840 & 0.401 & -.0214017 & .053465 \\
\hline manage & .0361907 & .4407311 & 0.082 & 0.935 & -.8281712 & .9005526 \\
\hline ownshr & -.0093616 & .0074957 & -1.249 & 0.212 & -.0240622 & .005339 \\
\hline tcuse & -.5912233 & .3540416 & -1.670 & 0.095 & -1.28557 & .1031232 \\
\hline ind_1 & .5349364 & 1.133446 & 0.472 & 0.637 & -1.687978 & 2.757851 \\
\hline ind_3 & 1.274546 & 1.095538 & 1.163 & 0.245 & -.8740234 & 3.423115 \\
\hline ind_4 & 1.104027 & 1.175258 & 0.939 & 0.348 & -1.200888 & 3.408943 \\
\hline ind_5 & .6646666 & 1.085321 & 0.612 & 0.540 & -1.463864 & 2.793198 \\
\hline ind_ 6 & .6230336 & 1.094444 & 0.569 & 0.569 & -1.523391 & 2.769458 \\
\hline
\end{tabular}




\begin{tabular}{|c|c|c|c|c|c|c|}
\hline ind_7 & 1.777271 & 1.122648 & 1.583 & 0.114 & -.4244676 & 3.979009 \\
\hline ind_8 & .3845042 & 1.094064 & 0.351 & 0.725 & -1.761174 & 2.530182 \\
\hline ind_9 & -.2761231 & 1.103191 & -0.250 & 0.802 & -2.439701 & 1.887455 \\
\hline $\mathrm{ms} a$ & .6310185 & .6750473 & 0.935 & 0.350 & -.6928845 & 1.954921 \\
\hline region2 & -6.806569 & 1.574168 & -4.324 & 0.000 & -9.893828 & -3.719311 \\
\hline region3 & .3845067 & .6905469 & 0.557 & 0.578 & -.9697941 & 1.738808 \\
\hline region 4 & 1.036104 & .7547769 & 1.373 & 0.170 & -.4441649 & 2.516373 \\
\hline region5 & .610915 & .7501525 & 0.814 & 0.416 & -.8602843 & 2.082114 \\
\hline region 6 & .1387811 & .6585128 & 0.211 & 0.833 & -1.152694 & 1.430257 \\
\hline region 7 & 1.149356 & .7030087 & 1.635 & 0.102 & -.2293845 & 2.528097 \\
\hline region 8 & -.2443715 & .770941 & -0.317 & 0.751 & -1.756341 & 1.267598 \\
\hline region 9 & -.3225525 & .6745395 & -0.478 & 0.633 & -1.645459 & 1.000354 \\
\hline loan 4 & 1.356737 & .4827203 & 2.811 & 0.005 & .4100261 & 2.303449 \\
\hline j5_asst & .0424198 & .0434634 & 0.976 & 0.329 & -.0428207 & .1276603 \\
\hline use_mrl & .8555328 & .3939477 & 2.172 & 0.030 & .0829224 & 1.628143 \\
\hline lend_src & -.278055 & .2010744 & -1.383 & 0.167 & -.6724022 & .1162923 \\
\hline mrl_prim & -.6330746 & .3681434 & -1.720 & 0.086 & -1.355078 & .0889284 \\
\hline mrl_9394 & -1.068593 & .4551489 & -2.348 & 0.019 & -1.961231 & -.1759548 \\
\hline _cons & -.3460168 & 2.459082 & -0.141 & 0.888 & -5.16877 & 4.476736 \\
\hline
\end{tabular}


RateLOC: Interest rate on most recent line of credit Model 4

Survey linear regression

$\begin{array}{ll}\text { pweight: } & \text { new_wgt } \\ \text { Strata: } & \text { newstrat } \\ \text { PSU: } & \text { <observations> }\end{array}$

Subpopulation no. of obs $=1001$ Subpopulation size $\quad=71902374$

$\begin{array}{llr}\text { Number of obs } & = & 1682 \\ \text { Number of strata } & = & 65 \\ \text { Number of PSUs } & = & 1682 \\ \text { Population size } & = & 1.378 e+08 \\ \text { F (73, 1545) } & = & 8.77 \\ \text { Prob }>\text { F } & = & 0.0000 \\ \text { R-squared } & = & 0.3641\end{array}$

\begin{tabular}{|c|c|c|c|c|c|c|}
\hline intrate & Coef. & Std. Err. & t & $P>|t|$ & [95\% Conf. & Interval] \\
\hline afam & -.6560109 & .6187905 & -1.060 & 0.289 & -1.869726 & .5577046 \\
\hline hispan & -2.123856 & .9851314 & -2.156 & 0.031 & -4.056124 & -.1915875 \\
\hline asian & .6051959 & .6496487 & 0.932 & 0.352 & -.6690459 & 1.879438 \\
\hline female & .3298722 & .5175852 & 0.637 & 0.524 & -.6853361 & 1.34508 \\
\hline hhi & -.9951155 & .8040823 & -1.238 & 0.216 & -2.572268 & .5820373 \\
\hline $\operatorname{afam} *$ hhi & 1.601559 & 2.909409 & 0.550 & 0.582 & -4.10505 & 7.308167 \\
\hline hisp*hhi & 12.39563 & 5.606299 & 2.211 & 0.027 & 1.399256 & 23.39201 \\
\hline $\operatorname{asn} * h h i$ & -1.017043 & 4.020739 & -0.253 & 0.800 & -8.903448 & 6.869363 \\
\hline $\mathrm{fml} * \mathrm{hhi}$ & -1.432557 & 2.43404 & -0.589 & 0.556 & -6.206762 & 3.341647 \\
\hline Inasset & .0036621 & .1031739 & 0.035 & 0.972 & -.1987064 & .2060306 \\
\hline Intotemp & -.1393115 & .0824975 & -1.689 & 0.091 & -.3011248 & .0225018 \\
\hline saleasst & -.0058321 & .0067987 & -0.858 & 0.391 & -.0191672 & .007503 \\
\hline liabasst & .3347048 & .0828702 & 4.039 & 0.000 & .1721605 & .4972492 \\
\hline profasst & -.0104409 & .0193518 & -0.540 & 0.590 & -.0483982 & .0275164 \\
\hline bankrupt & 1.204694 & .6225928 & 1.935 & 0.053 & -.0164791 & 2.425868 \\
\hline pdelinq1 & .1296381 & .5499143 & 0.236 & 0.814 & -.9489814 & 1.208258 \\
\hline pdelinq2 & .9158282 & .3668132 & 2.497 & 0.013 & .196349 & 1.635308 \\
\hline pdelinq3 & .3552549 & .3384186 & 1.050 & 0.294 & -.3085303 & 1.01904 \\
\hline bdelinq1 & -.1993436 & .5103212 & -0.391 & 0.696 & -1.200304 & .8016168 \\
\hline bdelinq2 & .0515464 & .3222174 & 0.160 & 0.873 & -.5804612 & .6835539 \\
\hline bdeling3 & -.4281183 & .2083355 & -2.055 & 0.040 & -.8367543 & -.0194823 \\
\hline judgment & -.4952485 & .5038323 & -0.983 & 0.326 & -1.483481 & .4929844 \\
\hline credscr & -.006761 & .0023168 & -2.918 & 0.004 & -.0113052 & -.0022168 \\
\hline fin_jbnk & 2.53207 & .8947086 & 2.830 & 0.005 & .77716 & 4.28698 \\
\hline rel_jbnk & .0082579 & .0091103 & 0.906 & 0.365 & -.0096113 & .0261271 \\
\hline $\operatorname{ccorp}$ & -.1707104 & .2643272 & -0.646 & 0.518 & -.6891703 & .3477494 \\
\hline scorp & -.2705093 & .2684065 & -1.008 & 0.314 & -.7969704 & .2559518 \\
\hline partner & -.2532384 & .3522313 & -0.719 & 0.472 & -.9441161 & .4376393 \\
\hline Inage2 & .0083528 & .0968138 & 0.086 & 0.931 & -.1815409 & .1982464 \\
\hline franchis & .2637244 & .3167857 & 0.833 & 0.405 & -.3576292 & .8850781 \\
\hline d6_natn & .2049917 & .2007292 & 1.021 & 0.307 & -.1887249 & .5987084 \\
\hline d6_outsd & .7693182 & .4287744 & 1.794 & 0.073 & -.0716936 & 1.61033 \\
\hline$\overline{\mathrm{d}} 6 \_r e g$ & .4116687 & .1812026 & 2.272 & 0.023 & .0562521 & .7670853 \\
\hline checking & -2.185741 & .6671172 & -3.276 & 0.001 & -3.494246 & -.8772358 \\
\hline saving & .2335393 & .1483574 & 1.574 & 0.116 & -.0574537 & .5245322 \\
\hline not_hs & -.1734908 & .4083704 & -0.425 & 0.671 & -.9744817 & .6275 \\
\hline collège & -.04014 & .2054633 & -0.195 & 0.845 & -.4431424 & .3628623 \\
\hline exper & -.000837 & .0073599 & -0.114 & 0.909 & -.0152731 & .013599 \\
\hline manage & -.3223913 & .1903447 & -1.694 & 0.091 & -.6957396 & .050957 \\
\hline ownshr & -.0004231 & .0027408 & -0.154 & 0.877 & -.005799 & .0049527 \\
\hline tcuse & -.1612073 & .1703936 & -0.946 & 0.344 & -.4954229 & .1730082 \\
\hline ind_1 & .4529234 & .3709717 & 1.221 & 0.222 & -.2747125 & 1.180559 \\
\hline ind_3 & -.0527458 & .326003 & -0.162 & 0.871 & -.6921786 & .5866871 \\
\hline ind_4 & .1437242 & .4329702 & 0.332 & 0.740 & -.7055174 & .9929658 \\
\hline ind_5 & -.5830754 & .360975 & -1.615 & 0.106 & -1.291103 & .1249526 \\
\hline
\end{tabular}




\begin{tabular}{|c|c|c|c|c|c|c|}
\hline ind_6 & -.039323 & .3348181 & -0.117 & 0.907 & -.696046 & .6174 \\
\hline ind_7 & -.0250409 & .3897296 & -0.064 & 0.949 & -.7894691 & .7393873 \\
\hline ind_8 & .0022949 & .3188308 & 0.007 & 0.994 & -.62307 & .6276597 \\
\hline ind_9 & .1229478 & .3291272 & 0.374 & 0.709 & -.5226129 & .7685085 \\
\hline $\mathrm{msa}$ & -.2800313 & .1963642 & -1.426 & 0.154 & -.6651864 & .1051237 \\
\hline region2 & -.1671431 & .3000498 & -0.557 & 0.578 & -.7556705 & .4213843 \\
\hline region3 & -.1816678 & .2416445 & -0.752 & 0.452 & -.6556371 & .2923016 \\
\hline region 4 & -.2189838 & .3266158 & -0.670 & 0.503 & -.8596185 & .4216509 \\
\hline region 5 & -.3070251 & .3342644 & -0.919 & 0.358 & -.962662 & .3486118 \\
\hline region 6 & .91789 & .2537269 & 3.618 & 0.000 & .4202219 & 1.415558 \\
\hline region 7 & -.3288677 & .2123095 & -1.549 & 0.122 & -.7452984 & .0875631 \\
\hline region 8 & .911531 & .2856032 & 3.192 & 0.001 & .3513397 & 1.471722 \\
\hline region 9 & .1448836 & .247126 & 0.586 & 0.558 & -.3398372 & .6296045 \\
\hline bondsprd & -.02616 & .3256476 & -0.080 & 0.936 & -.6648957 & .6125757 \\
\hline termprem & -.2289627 & .164169 & -1.395 & 0.163 & -.5509692 & .0930437 \\
\hline mrl_indx & .7237643 & .1010647 & 7.161 & 0.000 & .5255329 & .9219958 \\
\hline fixed & .3290422 & .255195 & 1.289 & 0.197 & -.1715054 & .8295898 \\
\hline pcol & -.0349054 & .1623716 & -0.215 & 0.830 & -.3533862 & .2835754 \\
\hline $\mathrm{bcol}$ & .4283849 & .1492447 & 2.870 & 0.004 & .1356515 & .7211183 \\
\hline guar & -.0578959 & .1610784 & -0.359 & 0.719 & -.3738402 & .2580484 \\
\hline lend_src & .0214961 & .0530574 & 0.405 & 0.685 & -.0825724 & .1255646 \\
\hline loan 4 & .0617827 & .1806012 & 0.342 & 0.732 & -.2924543 & .4160198 \\
\hline mrl_9394 & -.505437 & .2777224 & -1.820 & 0.069 & -1.050171 & .0392966 \\
\hline mrl_prim & -.1664903 & .2215859 & -0.751 & 0.453 & -.601116 & .2681355 \\
\hline edenall & .3856946 & .264888 & 1.456 & 0.146 & -.1338653 & .9052544 \\
\hline invmat & .1630452 & .701796 & 0.232 & 0.816 & -1.21348 & 1.53957 \\
\hline lnamtbrr & -.2201448 & .0910297 & -2.418 & 0.016 & -.3986934 & -.0415962 \\
\hline points & .0051971 & .0950354 & 0.055 & 0.956 & -.1812084 & .1916026 \\
\hline fee_amt & 1.068651 & 1.606493 & 0.665 & 0.506 & -2.082375 & 4.219677 \\
\hline _cons & 7.26014 & 2.298427 & 3.159 & 0.002 & 2.75193 & 11.76835 \\
\hline
\end{tabular}




\title{
Estimated Coefficients for Loan Analysis - Model 4
}

\author{
Loan: Firm has loans
}

Model 4

Survey logistic regression

$\begin{array}{ll}\text { pweight: } & \text { new_wgt } \\ \text { Strata: } & \text { newstrat } \\ \text { PSU: } & \text { <observations> }\end{array}$

$\begin{array}{llr}\text { Number of obs } & = & 4570 \\ \text { Number of strata } & = & 65 \\ \text { Number of PSUs } & = & 4570 \\ \text { Population size } & = & 4.898 e+08 \\ \text { F( 61, 4445) } & = & 8.85 \\ \text { Prob > F } & = & 0.0000\end{array}$

\begin{tabular}{|c|c|c|c|c|c|c|}
\hline loan & Coef. & Std. Err. & $t$ & $\mathrm{P}>|\mathrm{t}|$ & [95\% Conf. & Interval] \\
\hline afam & -.1066299 & .2846705 & -0.375 & 0.708 & -.6647237 & .451464 \\
\hline hispan & .5198318 & .33925 & 1.532 & 0.126 & -.1452646 & 1.184928 \\
\hline asian & -.269711 & .4088522 & -0.660 & 0.509 & -1.071262 & .5318399 \\
\hline female & -.0659963 & .2522783 & -0.262 & 0.794 & -.5605856 & .4285929 \\
\hline hhi & .1805816 & .6385655 & 0.283 & 0.777 & -1.07132 & 1.432483 \\
\hline afam*hhi & -.1656297 & 1.310497 & -0.126 & 0.899 & -2.734847 & 2.403588 \\
\hline hisp*hhi & -1.80436 & 1.500708 & -1.202 & 0.229 & -4.746484 & 1.137763 \\
\hline $\operatorname{asn} * h h i$ & -.5421558 & 2.130546 & -0.254 & 0.799 & -4.71907 & 3.634759 \\
\hline $\mathrm{fml} * \mathrm{hhi}$ & .2388213 & 1.062363 & 0.225 & 0.822 & -1.843932 & 2.321575 \\
\hline Inasset & .3360547 & .0441561 & 7.611 & 0.000 & .2494871 & .4226223 \\
\hline Intotemp & .148892 & .0641233 & 2.322 & 0.020 & .0231789 & .2746052 \\
\hline saleasst & -.0043073 & .0058998 & -0.730 & 0.465 & -.0158737 & .0072592 \\
\hline liabasst & .3706168 & .1522642 & 2.434 & 0.015 & .0721042 & .6691293 \\
\hline profasst & -.0031909 & .0111929 & -0.285 & 0.776 & -.0251344 & .0187526 \\
\hline bankrupt & -.4465806 & .3373745 & $-1 \cdot 324$ & 0.186 & -1.108 & .214839 \\
\hline pdeling1 & -.2693831 & .2930867 & -0.919 & 0.358 & -.8439768 & .3052106 \\
\hline pdelinq2 & -.225176 & .3278059 & -0.687 & 0.492 & -.8678364 & .4174844 \\
\hline pdelinq3 & -.3761533 & .2354101 & -1.598 & 0.110 & -.8376726 & .0853661 \\
\hline bdelinq1 & -.064725 & .2906556 & -0.223 & 0.824 & -.6345526 & .5051026 \\
\hline bdelinq2 & .2994027 & .2678076 & 1.118 & 0.264 & -.2256316 & .8244369 \\
\hline bdeling3 & .597937 & .2059071 & 2.904 & 0.004 & .1942581 & 1.001616 \\
\hline judgment & -.3115386 & .2502453 & -1.245 & 0.213 & -.8021422 & .179065 \\
\hline credscr & .002362 & .001955 & 1.208 & 0.227 & -.0014707 & .0061946 \\
\hline prim_fin & .237265 & .3083673 & 0.769 & 0.442 & -.3672862 & .8418163 \\
\hline rel_prim & -.0169584 & .0076695 & -2.211 & 0.027 & -.0319944 & -.0019223 \\
\hline ccorp & -.2471284 & .154792 & -1.597 & 0.110 & -.5505967 & .0563398 \\
\hline scorp & -.1057385 & .172252 & -0.614 & 0.539 & -.4434369 & .2319599 \\
\hline partner & -.0094836 & .2351132 & -0.040 & 0.968 & -.4704208 & .4514535 \\
\hline Inage & -.0649613 & .0893638 & -0.727 & 0.467 & -.2401581 & .1102356 \\
\hline franchis & -.0292559 & .3108318 & -0.094 & 0.925 & -.6386387 & .580127 \\
\hline d6_natn & .1231179 & .1957733 & 0.629 & 0.529 & -.2606937 & .5069295 \\
\hline d6_outsd & -.563373 & .429375 & $-1 \cdot 312$ & 0.190 & -1.405159 & .2784126 \\
\hline d6_reg & .2553822 & .1192382 & 2.142 & 0.032 & .0216168 & .4891476 \\
\hline checking & -.4619435 & .3918986 & -1.179 & 0.239 & -1.230257 & .3063701 \\
\hline saving & -.5297935 & .1364577 & -3.882 & 0.000 & -.7973177 & -.2622694 \\
\hline not_hs & -.1780722 & .242628 & -0.734 & 0.463 & -.6537421 & .2975978 \\
\hline college & -.1242897 & .1179613 & -1.054 & 0.292 & -.3555517 & .1069723 \\
\hline exper & -.0133301 & .005676 & -2.348 & 0.019 & -.0244579 & -.0022023 \\
\hline manage & .1183073 & .1567332 & 0.755 & 0.450 & -.1889666 & .4255812 \\
\hline ownshr & .005174 & .0027912 & 1.854 & 0.064 & -.0002981 & .010646 \\
\hline tcuse & .1653406 & .1066945 & 1.550 & 0.121 & -.043833 & .3745143 \\
\hline ind_1 & -.001419 & .2589949 & -0.005 & 0.996 & -.5091762 & .5063381 \\
\hline ind_3 & -.3589117 & .3240423 & -1.108 & 0.268 & -.9941936 & .2763702 \\
\hline
\end{tabular}




\begin{tabular}{|c|c|c|c|c|c|c|}
\hline ind_4 & .0893526 & .3941012 & 0.227 & 0.821 & -.6832792 & .8619843 \\
\hline ind_5 & -.5729263 & .2839115 & -2.018 & 0.044 & -1.129532 & -.0163204 \\
\hline ind_6 & -.4418969 & .2513694 & -1.758 & 0.079 & -.9347042 & .0509104 \\
\hline ind_7 & -.6652789 & .3037321 & -2.190 & 0.029 & -1.260743 & -.0698149 \\
\hline ind_8 & -.3616315 & .2458773 & -1.471 & 0.141 & -.8436716 & .1204086 \\
\hline ind_9 & -.6269715 & .2631277 & -2.383 & 0.017 & -1.142831 & -.1111122 \\
\hline $\mathrm{msa}$ & -.5332129 & .1518103 & -3.512 & 0.000 & -.8308356 & -.2355901 \\
\hline region2 & .4685657 & .294039 & 1.594 & 0.111 & -.1078949 & 1.045026 \\
\hline region 3 & -.137883 & .1831924 & -0.753 & 0.452 & -.4970301 & .221264 \\
\hline region 4 & .1971285 & .2453462 & 0.803 & 0.422 & -.2838704 & .6781275 \\
\hline region 5 & -.3134327 & .2350897 & -1.333 & 0.183 & -.7743238 & .1474584 \\
\hline region 6 & -.3355326 & .173413 & -1.935 & 0.053 & -.6755072 & .004442 \\
\hline region 7 & -.0550128 & .1766935 & -0.311 & 0.756 & -.4014186 & .2913931 \\
\hline region 8 & .584098 & .2074995 & 2.815 & 0.005 & .1772971 & .9908989 \\
\hline region 9 & .1052458 & .1891913 & 0.556 & 0.578 & -.265662 & .4761535 \\
\hline sources & 1.442791 & .0941195 & 15.329 & 0.000 & 1.258271 & 1.627311 \\
\hline edenall & .8327435 & .2048551 & 4.065 & 0.000 & .431127 & 1.23436 \\
\hline fearden 2 & .0516637 & .1359893 & 0.380 & 0.704 & -.2149419 & .3182694 \\
\hline _cons & -.3826566 & .6124468 & -0.625 & 0.532 & -1.583353 & .8180397 \\
\hline
\end{tabular}

